TITLE:

\title{
Studies on the Phylogenetic Implications of Ontogenetic Features in the Poecilostome Nauplii (Copepoda : Cyclopoida)
}

\author{
AUTHOR(S): \\ Izawa, Kunihiko
}

\section{CITATION:}

Izawa, Kunihiko. Studies on the Phylogenetic Implications of Ontogenetic Features in the Poecilostome Nauplii (Copepoda: Cyclopoida). PUBLICATIONS OF THE SETO MARINE BIOLOGICAL LABORATORY 1987, 32(4-6): 151-217

ISSUE DATE:

1987-12-26

URL:

http://hdl.handle.net/2433/176145

RIGHT: 


\title{
Studies on the Phylogenetic Implications of Ontogenetic Features in the Poecilostome Nauplii (Copepoda : Cyclopoida)
}

\author{
By \\ Kunihiko Izawa \\ Faculty of Bioresources, Mie University, Tsu, Mie 514, Japan
}

With Text-figures $1-17$ and Tables $1-3$

\section{Introduction}

The Copepoda includes a number of species that are parasitic or semi-parasitic on/in various aquatic animals (see Wilson, 1932). They live in association with particular hosts and exhibit various reductive tendencies (Gotto, 1979; Kabata, 1979). The reductive tendencies often appear as simplification and/or reduction of adult appendages, which have been considered as important key characters in their taxonomy and phylogeny (notably Wilson, op. cit.; Kabata, op. cit.). Larval morphology has not been taken into taxonomic and phylogenetic consideration. This is particularly unfortunate when dealing with the poecilostome Cyclopoida, which include many species with transformed adults. Our knowledge on the ontogeny of the Copepoda have been accumulated through the efforts of many workers (see references), but still it covers only a small part of the Copepoda. History of study on the nauplii of parasitic copepods goes back to the 1830 's, as seen in the description of a nauplius of Lernaea (see Nordmann, 1832). I have been studying the ontogeny of the parasitic and semi-parasitic Copepoda since 1969 and have reported larval stages of various species (Izawa, 1969; 1973; 1975; 1986a, b). The cyclopoid copepods whose naupliar stages were studied are listed in Table 1. The poecilostome Cyclopoida comprises about a thousand and some hundred nominated species belonging to about forty families, but larval stages of most species remain unknown. Nevertheless, my studies on the features of the larval stages of some species of cyclopoids have revealed interesting cues for a renewed examination of the phylogeny of the poecilostome Gyclopoida.

In this paper, I shall describe the features of eggs and naupliar stages of the poecilostome Gyclopoida and then discuss their phylogenetic implications. The larval morphology of poecilostome Cyclopoida will be compared with that of other copepods and crustaceans such as Cirripedia, Ascothoracida, Facetotecta, and $\mathrm{My}$ stacocarida of the Maxillopoda and the Cephalocarida. The features characteristic

Publ. Seto Mar. Biol. Lab., 32 (4/6), 151-217, $1987 . \quad$ (Article 6) 
Table 1. List of cyclopoids with known naupliar stages.

Stages known are: $\mathrm{N}$, nauplius stage, and $\mathrm{MN}$, metanauplius stage.

\begin{tabular}{|c|c|c|}
\hline Species & Stages studied & References \\
\hline \multicolumn{3}{|c|}{ [poecilostome] } \\
\hline \multicolumn{3}{|l|}{ Ergasilidae } \\
\hline Ergasilus centrarchidarum & $\mathrm{N} 1-3, \mathrm{MN} 1-2$ & Wilson, 1911 \\
\hline E. minor & N $1-3$ & Halisch, 1940 \\
\hline E. sieboldi & N $1-3$ & Zmerzlaya, 1972 \\
\hline E. turgidus & N 1 & Kabata, 1976 \\
\hline E. lizae & N $1-3$ & Ben Hassine, 1983 \\
\hline Thersitina gasterostei & N 1-4 & Gurney, 1913 \\
\hline Sinergasilus major & N $1-5$ & Yin, 1957 \\
\hline S. lieni & N 1-3 & Mirzoeva, 1973 \\
\hline Neoergasilus japonicus & N 1-6 & Urawa et al., $1980 \mathrm{a}$ \\
\hline \multicolumn{3}{|l|}{ Oncaeidae } \\
\hline Oncaea mediterranea & N 3-5 & Hanaoka, 1952 b \\
\hline \multirow[t]{2}{*}{ o. media } & N $1-6$ & Björnberg, 1972 \\
\hline & N $1-6$ & Malt, 1982 \\
\hline O. venusta & N 1-6 & Koga, 1984 \\
\hline O. subtilis & N $1-6$ & Malt, 1982 \\
\hline \multicolumn{3}{|l|}{ Corycaeidae } \\
\hline Corycaeus sp. & $\mathrm{N} 1$ & Hanaoka, 1952 b \\
\hline C. anglicus & $\mathrm{N} 1-6$ & Johnson, G., 1969 \\
\hline Farranula (Corycella) gracilis & N $1,3-5$ & Björnberg, 1972 \\
\hline$F .(C$.$) rostrata$ & N 5 & $\longrightarrow$ \\
\hline Corycaeus (Onychocorycaeus) giesbrechti & N $1-2$ & $\longrightarrow$ \\
\hline C. (Ditrichocorycaeus) amazonicus & N $1-2$ & $\longrightarrow$ \\
\hline C. (Corycaeus) speciosus & N 1 & $\longrightarrow$ \\
\hline C. (D.) affinis & N $1-6$ & Koga, 1984 \\
\hline C. (O.) pacificus & $\mathrm{N} 2-4$ & - \\
\hline C. speciosus & $\mathrm{N} 2,4-5$ & - \\
\hline \multicolumn{3}{|l|}{ Clausidiidae } \\
\hline Hemicyclops adhaerens (as Lichomolgus adhaerens) & N 1 & Williams, 1907 \\
\hline H. adhaerens & prob. $\mathrm{N} 3,6$ & Faber, 1966 \\
\hline \multicolumn{3}{|l|}{ Nereicolidae } \\
\hline Serioides bocqueti & N $1-2$ & Garton, 1964 \\
\hline \multicolumn{3}{|l|}{ Taeniacanthidae } \\
\hline Taeniacanthus lagocephali & N $1-2$ & Izawa, 1986 a \\
\hline $\begin{array}{l}\text { Taeniastrotos pleuronichthydis (as Anchistortos } \\
\text { pleuronichthydis) }\end{array}$ & N $1-2$ & Izawa, 1986 b \\
\hline \multicolumn{3}{|l|}{ Bomolochidac } \\
\hline Bomolochus cuneatus & N 1 & Kabata, 1976 \\
\hline Holobomolochus spinulus & N 1 & - \\
\hline \multicolumn{3}{|l|}{ Tegobomolochidae } \\
\hline Tegobomolochus nasicola & N 1-3 & Izawa, $1986 \mathrm{~b}$ \\
\hline \multicolumn{3}{|l|}{ Lichomolgidae } \\
\hline Doridicola agilis (as Lichomolgus doridicola) & N 1 & Canu, 1892 \\
\hline D. longicauda (as Lichomolgus sepicola) & $\mathrm{N} 1$ & Pesta, 1909 \\
\hline Lichomolgus canui & N $1-6$ & Costanzo, 1969 \\
\hline Doridicola sepiae & N 1-2 & Izawa, $1986 \mathrm{~b}$ \\
\hline Nasomolgus firmus & N 1 & - \\
\hline
\end{tabular}


Table 1. (Cont.)

\begin{tabular}{|c|c|c|}
\hline Species & Stages studied & References \\
\hline \multicolumn{3}{|l|}{ Sabelliphilidae } \\
\hline Sabellipilus sarsi (as Lichomolgus sarsi) & N 1 & Valle, 1880 \\
\hline S. elongatus & $\mathrm{N} 1$ & Lang, 1949 \\
\hline Paranthessius anemoniae & N 1-6 & Briggs, 1977 \\
\hline \multicolumn{3}{|l|}{ Philoblennidae } \\
\hline Philoblenna arabici & N 1-3 & Izawa, $1986 \mathrm{~b}$ \\
\hline \multicolumn{3}{|l|}{ Myicolidae } \\
\hline Ostrincola koe & N 1-5 & Kô et al., 1974 \\
\hline Pseudomyicola spinosus (as Pseudomyicola ostreae) & N 1-6 & Nakamura et al., 1979 \\
\hline \multicolumn{3}{|l|}{ Anthessiidae } \\
\hline Neanthessizs renicolis & N 1-5 & Izawa, $1986 \mathrm{~b}$ \\
\hline Panaietis yamagutii & N $1-5$ & $\longrightarrow$ \\
\hline \multicolumn{3}{|l|}{ Mytilicolidae } \\
\hline \multirow[t]{3}{*}{ Mytilicola intestinalis } & N $1-2$ & Pesta, 1907 \\
\hline & N 1-2 & Caspers, 1939 \\
\hline & N 1-2 & Costanzo, 1959 \\
\hline Trochicola entericus & N $1-2$ & Bocquet et al., 1963 \\
\hline \multicolumn{3}{|l|}{ Philichthyidae } \\
\hline Lernaeascus nematoxys & N 1 & Claus, 1887 \\
\hline Colobomatus pupa & N 1--5 & Izawa, 1975 \\
\hline \multicolumn{3}{|l|}{ Sarcotacidae } \\
\hline \multirow[t]{2}{*}{ Sarcotaces aroticus } & N 1 & Hjort, 1895 \\
\hline & N 1 & Kuitunen-Ekbaum, 1949 \\
\hline \multirow[t]{2}{*}{ S. pacificus } & N 1 & Komai, 1924 \\
\hline & N $1-5$ & Izawa, 1973 \\
\hline Ichthyotaces pteroisicola & N 1 & Shiino, 1932 \\
\hline \multicolumn{3}{|l|}{ Chondracanthidae } \\
\hline Chondracanthus lophii & N 1 & Heegaard, 1947 \\
\hline Acanthochondria cornuta & N 1 & - \\
\hline Chondracanthus gracilis & N 1 & Kabata, 1976 \\
\hline Pseudacanthocanthopsis apogonis & N 1-3 & Izawa, $1986 \mathrm{~b}$ \\
\hline Praecidochondria setoensis & N 1-3 & - \\
\hline \multicolumn{3}{|l|}{ Gastrodelphyidae } \\
\hline Gastrodelphys fernaldi & N $1-2$ & Dudley, 1966 \\
\hline Sabellacheres illgi & N 1 -4 & - \\
\hline S. gracilis & N $1-4$ & - \\
\hline \multicolumn{3}{|l|}{ Cucumaricolidae } \\
\hline Cucumaricola notabilis & N 1 & Paterson, 1958 \\
\hline \multicolumn{3}{|l|}{ Lamippidae } \\
\hline Lamippe aciculifera & $\mathrm{N} 1$ & Bouligand, 1966 \\
\hline \multicolumn{3}{|c|}{ [systematic position uncertain] } \\
\hline \multicolumn{3}{|l|}{ Herpyllobiidae } \\
\hline Herpyllobius arcticus & N 1 & Lützen, 1968 \\
\hline H. polynoes & N 1 & $\longrightarrow$ \\
\hline Eurysilenium truncatum & N 1-2 & - \\
\hline \multicolumn{3}{|l|}{ Antheacheridae } \\
\hline \multirow[t]{2}{*}{ Antheacheres duebeni } & N 1 & Sars, 1870 \\
\hline & N 1-2 & Vader, 1970 \\
\hline Coelotrophus nudus & $\mathrm{N} 1$ & Quidor, 1922 \\
\hline
\end{tabular}


Table 1. (Cont.)

\begin{tabular}{|c|c|c|}
\hline Species & Stages studied & References \\
\hline & $\mathrm{N} 1$ & Taton, 1934 \\
\hline \multicolumn{3}{|l|}{ Spondinticolidae } \\
\hline $\begin{array}{l}\text { Spondinticola vermicularis (as Clionophilus vermi- } \\
\text { cularis) }\end{array}$ & N 1 & Silén, 1963 \\
\hline \multicolumn{3}{|l|}{ Xenocoelomidae } \\
\hline Xenocoeloma brumpti & N 1 & Caullery \& Mesnil, 1919 \\
\hline Aphanodomus terebellae & N 1 & Bresciani \& Lützen, 1974 \\
\hline \multicolumn{3}{|l|}{ Phyllodicolidae } \\
\hline Phyllodicola petiti & MN & Laubier, 1961 \\
\hline \multicolumn{3}{|l|}{ Family uncertain } \\
\hline Gonophysema gullmarensis & N 1 & Bresciani \& Lützen, 1961 \\
\hline \multicolumn{3}{|c|}{ [siphonostome] } \\
\hline \multicolumn{3}{|l|}{ Asterocheridae } \\
\hline Ascomyzon parvum & $\mathrm{N} 1$ & Lang, 1949 \\
\hline Echinocheres violaceus & $\mathrm{N} \mathrm{l}$ & - \\
\hline \multicolumn{3}{|l|}{ Choniostomatidae } \\
\hline \multirow[t]{2}{*}{ Choniosphaera cancrorum } & $\mathrm{N} 1$ & Connolly, 1929 \\
\hline & N 1 & Johnson, 1957 \\
\hline Lecithomyzon maenadis & N 1 & Fischer, 1956 \\
\hline Choniomyzon panuliri & $\mathrm{N} 1$ & Pillai, 1962 \\
\hline \multicolumn{3}{|l|}{ Cancerillidae } \\
\hline Cancerilla tubulata & N $1-6$ & Carton, 1968 \\
\hline \multicolumn{3}{|l|}{ Nanaspididae } \\
\hline \multirow[t]{2}{*}{ Allantogynus delamarei } & N 1-3 & Changeux, 1961 \\
\hline & stome] & \\
\hline \multicolumn{3}{|l|}{ Cyyclopidae } \\
\hline Cyclops aequoreus & N 1 & Ganu, 1892 \\
\hline \multirow[t]{2}{*}{ C. strenuus } & N $1-5$ & Dietrich, 1915 \\
\hline & N $1-6$ & Hanaoka, 1944 \\
\hline C. scutifer & N 1-6 & Elgmork \& Langeland, 1970 \\
\hline G. serrulatus & N $1-6$ & Hanaoka, 1944 \\
\hline C.fuscus & N $1-5$ & - \\
\hline C. leuckarti & N $1-6$ & - \\
\hline C. viridis & $\mathrm{N} 1-6$ & Amelina, 1927 \\
\hline C. phaleratus & N $1-2,4,6(?)$ & - \\
\hline G. dimorphus & $\mathrm{N} 1(?), 6$ & Johnson, 1953 \\
\hline C. $s p$. & N $1-6$ & Ziegelmayer, 1925 \\
\hline \multicolumn{3}{|l|}{ Oithonidae } \\
\hline Oithona similis & N $1-6$ & Oberg, 1906 \\
\hline O. helgolandica & N $1-6$ & Gibbons \& Ogilvie, 1933 \\
\hline o. spinirostris & N 1-6 & - \\
\hline O. nana & N $1-6$ & Murphy, 1923 \\
\hline (as Oithonina nana) & N 1-6 & Haq, 1965 a \\
\hline o. rigida & N $1-6$ & Rao, 1958 \\
\hline o. ovalis & N $1-6$ & Björnberg, 1972 \\
\hline O. simplex & N 1, 3-6 & — \\
\hline O. hebes & N $1-6$ & Goswami, 1975 \\
\hline \multirow[t]{2}{*}{ O. brevicornis } & N 1-6 & $\longrightarrow$ \\
\hline & N $1-6$ & Koga, 1984 \\
\hline
\end{tabular}


Table 1. (Cont.)

\begin{tabular}{|c|c|c|}
\hline Species' & Stages studied & References \\
\hline \multicolumn{3}{|l|}{ Notodelphyidae } \\
\hline Notodelphys agilis & N 1, MN 1-3 & Canu, 1892 \\
\hline N. allmani & N $1-2$, MN 1 & - \\
\hline Doropygus gibber & $\mathrm{N} 1, \mathrm{MN} 1$ & $\longrightarrow$ \\
\hline Bonnierilla longipes & $\mathrm{N} 1, \mathrm{MN} 1-2$ & - \\
\hline Doroixys uncinata & N 1, MN 1-2 & - \\
\hline Notodelpl.ys affinis & N $1-5$ & Dudley, 1966 \\
\hline Doropygopsis longicauda & N 1-5 & — \\
\hline Pygodelphys aquilonaris & N 1-5 & - \\
\hline Doropygus seclusus & N 1-5 & - \\
\hline D. bayeri & N $1-5$ & $\longrightarrow$ \\
\hline D. mohri & N $1-5$ & $\longrightarrow$ \\
\hline D. fernaldi & N $1-5$ & $\longrightarrow$ \\
\hline Scolecodes huntsmani & N 1-4 & $\longrightarrow$ \\
\hline \multicolumn{3}{|l|}{ Ascidicolidae } \\
\hline Zanclopus antarcticus & N 1 & Gravier, 1913 \\
\hline Ascidicola rosea & N $1 \cdots 4$ & Gotto, 1957 \\
\hline Haplostomella australiensis & $\mathrm{N} 1$ & Anderson \& Rossiter, 1969 \\
\hline H. distincta & N 1-3 & Ooishi, 1980 \\
\hline Haplosaccus elongatus & N $1-5$ & $\longrightarrow$ \\
\hline Haplostoma albicatum & N 1-5 & $\longrightarrow$ \\
\hline \multicolumn{3}{|l|}{ Enterocolidae } \\
\hline Enterocola fulgens & N 1 & Canu, 1892 \\
\hline Aplostoma brevicauda & N I-3 & $\longrightarrow$ \\
\hline Mycophilus rosovula & $\mathrm{N} 1$ & Gray, 1933 \\
\hline M. roseus & N 1 & Lang, 1948a \\
\hline Ophioseides joubini & $\mathrm{MN}$ & Chatton, 1909 \\
\hline \multicolumn{3}{|l|}{ Lernaeidae } \\
\hline \multirow[t]{6}{*}{ Lernaea cyprinacea } & N 1 & Nordman, 1832 \\
\hline & N $1-4$ & Wilson, 1918 \\
\hline & N 1-2 & Nakai, 1927 \\
\hline & N 1-4 & Stoliarow, 1936 \\
\hline & N $1-4$ & Kasahara, 1962 \\
\hline & N $1-3$ & Grabda, 1963 \\
\hline L. chackoensis & N 1-2 & Gnanamuthu, 1951 \\
\hline Afrolernaea longicolis & N $1-2$ & Fryer, 1956 \\
\hline Lamproglena chinensis & N 1-2 & Sproston et al., 1950 \\
\hline
\end{tabular}

to the poecilostome Cyclopoida or to its subgroups are noted and then the direction and degree of simplification in each structure will be shown. The scenario of abbreviation of the naupliar stage and the significance of such reduction are also investigated.

Although Kabata (1979) proposed a new scheme of relationships within the Copepoda with most of the parasitic forms, except monstrilloids, being included in the Suborders Cyclopoida, Poecilostomatoida and Siphonostomatoida and discarding the Caligoida and Lernaeopodoida, his new system is not adopted. In this paper, I followed G.O. Sars scheme of Copepoda, in wbich Cyclopoida (including Gnathostome, Poecilostome and Siphonostome), Caligoida, and Lernaeopodoida are recognized to contain most of the parasitic forms. Therefore, the poecilostome Cyclopoida defined in this paper is actually corresponding to Kabata's Poecilostomatoida. 
Chapter I. Features in the Egg and the Naupliar Stage

\section{Egg and egg sac}

In poecilostome cyclopoids, the eggs are laid usually in a pair of egg sacs carried by the female, though there are other types of spawning. Corycaeus japonicus of the Corycaeidae attaches the eggs on her legs (Chiba, 1956). In gall forming genera, Sarcotaces and Ichthyotaces of the Sarcotacidae, the eggs are shed free in the narrow space around the copepod body in the host (Komai, 1924; Shiino, 1932; Izawa, 1973, 1974). Sabellacheres and the most species of Gastrodelphys (Gastrodelphyidae) kept the eggs in the brood pouch, which is formed by invagination and posterior protrusion of the fifth thoracic segment (Dudley, 1964; Gotto, 1979). Phyllodicola petiti (Phyllodicolidae) (=Phyllocola petiti, Phylocolidae), though the systematic position is still uncertain, has a pair of egg-stalks, in which each egg is individually attached to the common axis by a short and thin peduncle (Delamare-Deboutteville \& Laubier, 1960; Laubier, 1961). The egg sac in the poecilostome Cyclopoida, if present, is not firmly secured and detachable from the mother as compared with those in the Caligoida and Lernaeopodoida. The egg sacs carried by the female in three major groups of parasitic copepods are shown in Fig. 1.

In the poecilostome Cyclopoida, the eggs are multiseriate, though in a few forms the eggs may arrange occasionally or consistently in a single row in a part or the whole length of the egg sac, e.g. Pseudoeucanthus nuiseriatus (Wilson, 1913), Spiophanicola spinulosus (Ho, 1984), some species of Ostrincola (see Tanaka, 1961), Mytilicola mactrae (Hoshina \& Kuwabara, 1959), Neanthessius renicolis (Izawa, 1976),

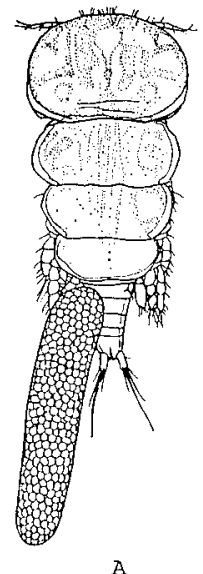

A Cyclopoida

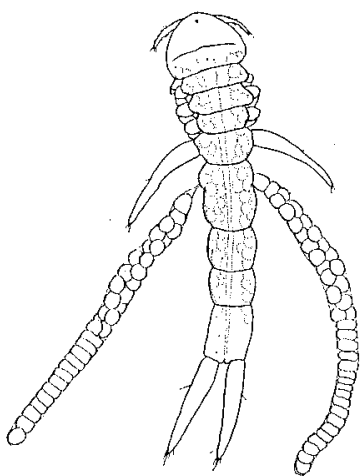

B

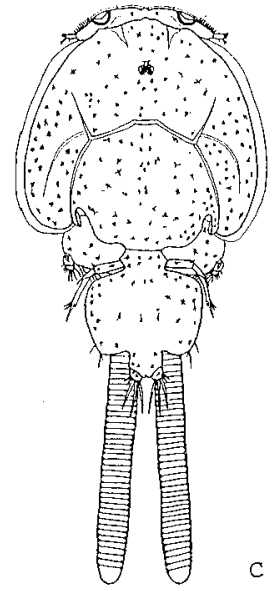

Caligoida

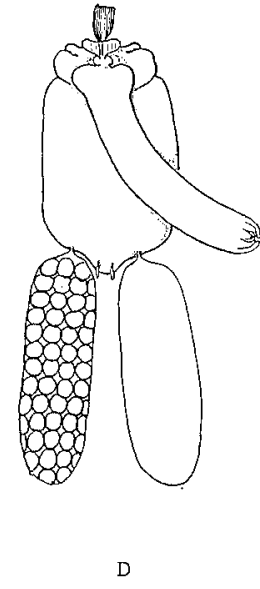

Lernaeopodoida

Fig. 1. Comparison of the egg sacs in parasitic Copepoda. Cyclopoida (A, Taeniacanthus and B, Neanthessius) (after Izawa, 1967, 1976); Caligoida (C, Caligus) (after Urawa et al., 1979); Lernacopodoida (D, Alella) (after Kawatow et al., 1980). 
species of Eunicicola (see Kurz, 1877; Gotto, 1963), Melinacheres ergasiloides (Bresciani \& Lützen, 1975), Akessonia occulta (Bresciani \& Lützen, 1962), and species of Vaigamidae (Thatcher \& Robertson, 1984; Thatcher \& Boeger, 1984a-c). Even in these cases, however, they are never strongly compressed as in the Caligoida. Among the Cyclopoida, species of Lamproglena and Afrolernaea (Lernaeidae, gnathostome Cyclopoida) have consistently a pair of uniseriate egg sacs (Fryer, 1956).

It should be noted that various modes of spawning are found in the Copepoda, including: (1) shedding eggs free in the water (Calanoida), (2) carrying adhesive eggs attached to her thoracic legs (Calanoida, Gyclopoida) or to two ventral setae of the genital segment, which are considered the rudimentary sixth legs (Monstrilloida, ? Phyllodicolidae), (3) carrying egg sac(s) (Calanoida, Harpacticoida, Cyclopoida, Caligoida, Lernaeopodoida), (4) carrying eggs in brood pouch (Cyclopoida). The Cyclopoida, especially the poecilostome Cyclopoida, is notable in exhibiting all modes of spawning except shedding the eggs free in water. On the other hand, in the strictly parasitic groups like Caligoida and Lernaeopodoida, as far as the extant representatives are concerned, the uniseriate and multiseriate egg sacs respectively are the rule. Thus, the features of egg sac and arrangement of eggs in them seem to be characteristic and useful as clues for a ready identification of parasitic copepods belonging to Cyclopoida, Caligoida and Lernaeopodoida. It is possible that similar spawning manner could have evolved in two or more different lineages or groups.

In parasitic copepods, there is a general trend to increase the eggs size and/or number, resulting in production of larger egg sacs. For the fish parasites, it seems to be vital to keep their large egg sacs against water current until just before hatching. This may be attained by two ways of adaptation, i.e. to strengthen the egg sac and to deform it into a thread-like for reducing resistance to water flow. In this respect, the poecilostome cyclopoids parasitic on fish are different from either caligoids or lernaeopodoids which are entirely fish parasites except Anchicaligus on Nautilus (Ho, 1980). Actually, habitat or its space where the poecilostome cyclopoids dwell is limited within enclosed places such as the bucco-branchial cavity, nasal cavity, sensory canal system, beneath scales, and in gall, where water current is relatively weak.

The egg size may safely be included in a range between 40 and $150 \mu \mathrm{m}$ in diameter in the poecilostome Cyclopoida except for some species belonging to the families Myicolidae and Gastrodelphyidae, which yield eggs more than $200 \mu \mathrm{m}$ in diameter (Table 2). This is clearly smaller than in the Caligoida and Lernaeopodoida, in which the eggs are generally $200-300 \mu \mathrm{m}$ in diameter. Interestingly, this range is much wider in the former due to inclusion of various life modes from free-living to parasitic. Accumulation of yolk in the egg or the increase of egg size in the parasitic or semi-parasitic forms seem to be related to the habitats where they reside on/in the hosts. The egg size, or essentially the amount of yolk, seems to genetically determined, whether or not the nauplius hatched from it needs feeding to grow to the first copepodid. The minimum egg size required to yield non-feeding, or lecithotrophic, nauplius is estimated to be about $120 \mu \mathrm{m}$ in diameter, based on my 
Table 2. Egg size and nutritional type of nauplii in the poecilostome Cyclopoida. Nutritional types referred to are: F, feeding and L, lecithotrophic. Numerals in the parentheses indicate the number of naupliar stages.

\begin{tabular}{|c|c|c|c|}
\hline Family & $\begin{array}{c}\text { Egg size } \\
(\mu \mathrm{m})\end{array}$ & $\begin{array}{c}\text { Type } \\
\text { (No. of } \\
\text { stages) }\end{array}$ & References \\
\hline \multicolumn{4}{|l|}{ Oncaeidae } \\
\hline Oncaea venusta & $40-60$ & $\mathrm{~F}(6)$ & Chiba, 1956; Koga, 1984 \\
\hline \multicolumn{4}{|l|}{ Corycaeidae } \\
\hline Corycaeus affinis & $60-80$ & $\mathrm{~F}(6)$ & Koga, 1984 \\
\hline \multicolumn{4}{|l|}{ Taeniacanthidae } \\
\hline Taeniacanthus lagocephali & 68 & $F(6 ?)$ & Izawa, 1986 a \\
\hline $\begin{array}{l}\text { Taeniastrotos pleuronichthydis (as Anchistrotos } \\
\text { pleuronichthydis) }\end{array}$ & 80 & $F(6 ?)$ & Izawa, 1986 b \\
\hline \multicolumn{4}{|l|}{ Tegobomolochidae } \\
\hline Tegobomolochus nasicola & $104 \times 92$ & $F(6 ?)$ & Izawa, 1986 b \\
\hline \multicolumn{4}{|l|}{ Ergasilidae } \\
\hline Neoergasilus japonicus & 80 & $F(6)$ & Urawa et al., $1980 \mathrm{a}$ \\
\hline \multicolumn{4}{|l|}{ Sabelliphilidae } \\
\hline Paranthessius anemoniae & 48 & $\mathrm{~F}(6)$ & Briggs, 1977 \\
\hline \multicolumn{4}{|l|}{ Lichomolgidae } \\
\hline Lichomolgus canui & $50 \times 45$ & $\mathrm{~F}(6)$ & Costanzo, 1969 \\
\hline Doridicola sepiae & 50 & $F(6 ?)$ & Izawa, $1986 \mathrm{~b}$ \\
\hline Nasomolgus firmus & $75-80$ & $\mathrm{~F}(6 ?)$ & Izawa, $1986 \mathrm{~b}$ \\
\hline \multicolumn{4}{|l|}{ Philoblennidae } \\
\hline Philoblenna arabici & $130 \times 120$ & $\mathrm{~L}(6 ?)$ & Izawa, $1986 \mathrm{~b}$ \\
\hline \multicolumn{4}{|l|}{ Myicolidae } \\
\hline Pseudomyicola spinosus (as Pseudomyicola ostreae) & $192-210$ & $\mathbf{L}(6)$ & Nakamura et al., 1979 \\
\hline Ostrincola koe & 130 & $L(5)$ & Kô et al., 1974 \\
\hline \multicolumn{4}{|l|}{ Anthessiidae } \\
\hline Neanthessius renicolis & $170 \times 130$ & $\mathrm{~L}(5)$ & Izawa, 1986 b \\
\hline Panaietis yamagutii & $145 \times 134$ & $\mathrm{~L}(5)$ & Izawa, 1986 b \\
\hline \multicolumn{4}{|l|}{ Philichthyidae } \\
\hline Colobomatus pupa & $120 \times 80$ & $\mathrm{~L}(5)$ & Izawa, 1975 \\
\hline \multicolumn{4}{|l|}{ Sarcotacidae } \\
\hline Sarcotaces pacificus & $140 \times 110$ & $\mathrm{~L}(5)$ & Izawa, 1973 \\
\hline \multicolumn{4}{|l|}{ Gastrodelphyidae } \\
\hline Sabellacheres illgi & $360 \times 190$ & $L(4 ?)$ & Dudley, 1964 \\
\hline S. gracilis & $180 \times 120$ & $\mathrm{~L}(4 ?)$ & Dudley, 1964 \\
\hline Gastrodelphys fernaldi & $260 \times 180$ & $\mathrm{~L}(2)$ & Dudley, 1964 \\
\hline \multicolumn{4}{|l|}{ Chondracanthidae } \\
\hline Pseudacanthocanthopsis apogonis & 120 & $\mathrm{~L}(3)$ & Izawa, $1986 \mathrm{~b}$ \\
\hline Praecidochondria setoensis & 145 & $\mathrm{~L}(3)$ & Izawa, 1986 b \\
\hline \multicolumn{4}{|l|}{ Mytilicolidae } \\
\hline Mytilicola intestinalis & $130-150$ & $\mathrm{~L}(2)$ & $\begin{array}{l}\text { Pesta, 1907; Caspers, 1939; } \\
\text { Costanzo, 1959 }\end{array}$ \\
\hline Trochicola entericus & $150 \times 125$ & $L(2)$ & Bocquet et al., 1963 \\
\hline \multicolumn{4}{|l|}{ Nereicolidae } \\
\hline Serioides bocqueti & $120 \times 100$ & $\mathrm{~L}(2)$ & Carton, 1964 \\
\hline \multicolumn{4}{|c|}{ [systematic position uncertain] } \\
\hline $\begin{array}{l}\text { Antheacheridae } \\
\text { Antheacheres duebeni }\end{array}$ & $170-180$ & $L(2 ?)$ & Vader, 1970 \\
\hline
\end{tabular}


Table 2. (Cont.)

\begin{tabular}{|c|c|c|c|}
\hline Family & $\begin{array}{c}\text { Egg size } \\
\qquad(\mu \mathrm{m})\end{array}$ & $\begin{array}{c}\text { Type } \\
\text { (No. of } \\
\text { stages) }\end{array}$ & References \\
\hline \multicolumn{4}{|l|}{ Herpyllobiidae } \\
\hline Eurysilenium truncatum & $95-118$ & $\mathrm{~L}(2 ?)$ & Lützen, 1968 \\
\hline Herpyllobius arcticus & 130 & $\mathrm{~L}(2 ?)$ & Lützen, 1968 \\
\hline H. polynoes & 125 & $\mathrm{~L}(2 ?)$ & Lützen, 1968 \\
\hline \multicolumn{4}{|l|}{ Xenocoelomidae } \\
\hline Aphanodomus terebellae & $100-130$ & L ? & Bresciani \& Lützen, 1974 \\
\hline \multicolumn{4}{|l|}{ Family uncertain } \\
\hline Gonophysema gullmarensis & $130-160$ & $\mathrm{~L}(1)$ & $\begin{array}{l}\text { Bresciani \& Lützen, } 1960 \text {, } \\
1961\end{array}$ \\
\hline
\end{tabular}

observation and available data in literature. The nutritional type of nauplius, hereafter referred to as "lecithotrophic" means non-feeding throughout the naupliar life. The first one or two naupliar stages do not feed even in the "feeding" type of nauplius.

\section{Naupliar stage}

Based on studies of the post-embryonic development of free-living copepods, mostly the gnathostome forms, it can be assumed that the naupliar phase is consisting of six stages in the Cyclopoida, as in the Calanoida and Harpacticoida (Hanaoka, 1952a; Elgmork \& Langeland, 1970). Although our knowledges on the ontogeny of free-living and symbiotic poecilostome cyclopoids are still insufficient and the exact number of their naupliar stages is yet to be confirmed in some major groups such as Clausidiidae, Sapphirinidae, Taeniacanthidae and Bomolochidae, it seems certain that the species laying eggs smaller than about $120 \mu \mathrm{m}$ in diameter have the basic six stages.

Accumulation of yolk in the egg seems to cause, following the production of non-feeding nauplii, their morphological simplification and reduction in number of the naupliar stages. The number of the naupliar stages varies from six to one. The fact that the larval stages are also abbreviated in the species yielding the large eggs in palaemonid prawns (Sollaud, 1923; Shokita, 1973) indicates that the simplification of naupliar morphology and reduction of the number of stages can be an independent evolutionary event.

Although, generally, the reduction in the number of naupliar stages is greater in the groups with highly transformed adult, the degree of adult transformation does not necessarily coincide with that of naupliar stage reduction. For example, the adult of Sarcotaces is more transformed than that of chondracanthids, but it has five nauplius stages, with two more stages than in the latter (Izawa, 1973, 1986b). Furthermore, even within the same family, the number of naupliar stages can differ. For example, in the Anthessiidae, which was recently separated from the Myicolidae by Humes (1986), Panaietis and Neanthessius have lecithotrophic five naupliar 
stages (Izawa, 1986b), while two other genera, Anthessius and katanthessius, have probably feeding nauplii composed of six stages, judging from their egg sizes which are estimated to be 40-90 $\mu \mathrm{m}$ in diameter. In the Myicolidae, Pseudomyicola (= Midicola, see Stock, 1969) has lecithotrophic six naupliar stages (Nakamura et al., 1979), while Ostrincola has lecithotrophic five naupliar stages (Kô et al., 1974). The matters are the same in the families Gastrodelphyidae (poecilostome Cyclopoida), Notodelphyidae and Ascidicolidae (gnathostome Cyclopoida). Among the Gastrodelphyidae, Sabellacheres has at least four stages, but there is only two in Gastrodelphys (Dudley, 1964). Among the Notodelphyidae, it is five in Notodelphys, Doropygus, Doropygopsis, and Pygodelphys, whereas probably four in Scolecodes (Dudley, 1966). Among the Ascidicolidae, it is also five in Haplosaccus and Haplostoma, but four in Ascidicola (Gotto, 1957) and three in Haplostomella (Ooishi, 1980).

As given in Table 3, very little growth is gained throughout the nauplius stages in the lecithotrophic nauplii. Generally, feeding nauplii are much smaller in the early stages (due to small egg size) than the lecithotrophic ones, but the former grow almost equal to or rather larger than the latter in later stages. This is clearly seen in Taeniacanthus lagocephali and Taeniastrotos pleuronichthydis (=Anchistrotos pleuronichthydis, Dojiri \& Cressey, 1987), in which the small first nauplii of $85 \times 45 \mu \mathrm{m}$ and $104 \times$ $56 \mu \mathrm{m}$ in size, grow respectively to the first copepodites of $330 \times 140 \mu \mathrm{m}$ and $353 \times$ $154 \mu \mathrm{m}$ in size, which are much larger than those yielded from the lecithotrophic nauplii. Similar trend with the last nauplii being nearly twice as large as the first nauplii is also known in free-living species, i.e. Oncaea, Corycaeus and Oithona (Haq, 1965a; Goswami, 1975; Malt, 1982; Koga, 1984).

\section{2-1. Morphological features.}

In this section, the general features of naupliar structure in poecilostome $\mathrm{Cy}$ clopoida including both the free-living and symbiotic forms will be dealt with. Of the thirteen species studied by Izawa $(1973,1975,1986 \mathrm{a}, \mathrm{b})$, six species are considered to have complete, or less simplified naupliar stage, they are Taeniacanthus lagocephali and Taeniastrotos pleuronichthydis (=Anchistrotos pleuronichthydis (Taeniacanthidae), Tegobomolochus nasicola (Tegobomolochidae, Avdeev, 1978), Doridicola sepiae and Nasomolgus firmus (Lichomolgidae), and Philoblenna arabici (Philoblennidae). Two species, Neanthessius renicolis and Panaietis yamagutii (Anthessiidae), have their nauplii somewhat simplified and the number of stages is reduced to five. The nauplii of Colobomatus pupa (Philihcthyidae), Sarcotaces pacificus (Sarcotacidae), and Pseudacanthocanthopsis apogonis and Praecidochondria setoensis (Chondracanthidae) are much simplified.

The body shape of the cyclopoid nauplii is fundamentally ovoid or pear-shaped. However the nauplii of the Harpacticoida are relatively broad and more or less discoid (see Tesch, 1915; Gurney, 1930; Nicholls, 1935, 1941; Fraser, 1936; Lang, 1948b; Johnson \& Olson, 1948; Krishnaswamy, 1950, 1955; Bresciani, 1960; Ummerkutty, 1960; Bernard, 1963; El-Maghraby, 1964; Haq, 1965b; Vilela, 1969; Itô, 1970, 1975; Carter \& Bradford, 1972; Koga, 1973, 1984; Hirakawa, 1974; 
Table 3. Growth of nauplii in body length and duration in the naupliar stages. Abbreviations $\mathrm{N}$, naupliar stage; $\mathrm{C}$, copepodid stage; d, day.

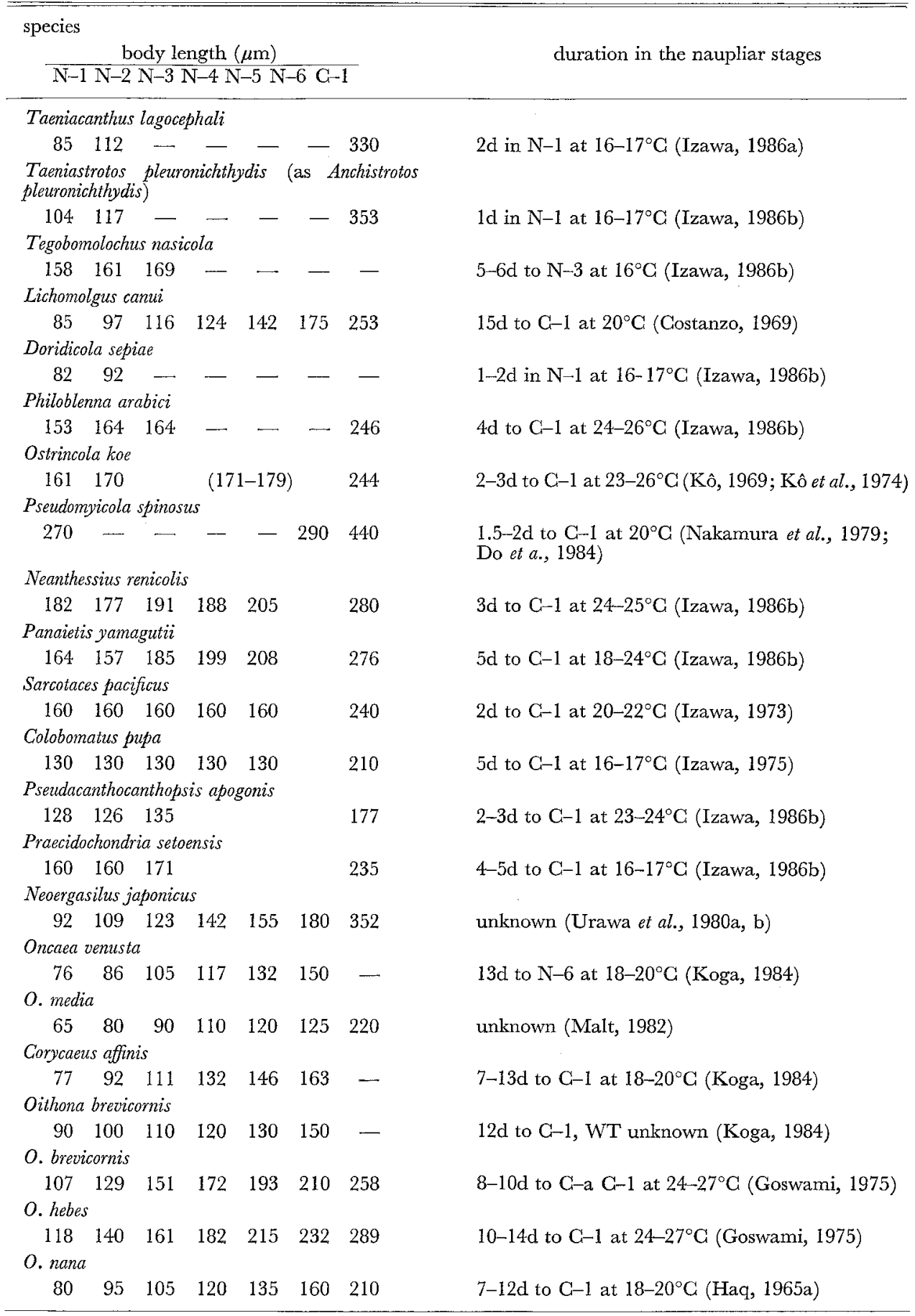


Itô \& Takashio, 1981; Schminke, 1982; Diaz \& Evans, 1983; Onbé, 1984; Bourguet, 1986). The nauplii of the Calanoida are in general elongate or bent ventrally at the posterior portion especially in later stages of development; it is due to the growth of the posterior portion of the body (see Oberg, 1906; Lebour, 1916; Campbell, 1934; Johnson, 1934a, b, 1935, 1937, 1948, 1965, 1966; Steuer, 1935; Humes, 1955; Conover, 1956; Koga, 1960a, b, 1968, 1984; Comita \& Tommerdahl, 1960; Gaudy, 1961; Ummerkutty, 1964; Bernard, 1964; Matthews, 1964; Shen \& Chang, 1965; Björnberg, 1966, 1972; Grice, 1969; Lawson \& Grice, 1970; Uye \& Onbé, 1975; Reddy \& Devi, 1985).

2-1-1. Furcal armature.

This is usually composed of paired setac and short spines, though in certain species an unpaired process (caudal process) is added medially between them. Composition of the furcal armature in each stage is shown diagrammatically in Fig. 2. Of the species dealt with by Izawa (1973, 1975, 1986a, b), Taeniacanthus lagocephali, Taeniastrotos pleuronichthydis (=Anchistrotos pleuronichthydis) and Tegobomolochus nasicola have the caudal process in the first and second naupliar stages. Existence of the caudal process seems to be common within the taeniacanthiform families, in which the related families Taeniacanthidae, Tuccidae, Bomolochidae, Tegobomolochidae, and Telsidae are gathered up tentatively as a natural group (cf. bomolochiform complex of Dojiri \& Cressey, 1987), since the process is found also in the nauplii of Bomolochus and Holobomolochus of the Bomolochidae (Kabata, 1976), though only the first stage is studied. Kabata (op. cit., p. 2523) has already mentioned the possibility of using caudal process in distinguishing bomolochid nauplii. The caudal process disappeared at the third naupliar stage in Tegobomolochus (Izawa, 1986b). A structure similar to this process is found also in the first nauplii of Doridicola sepiae and Nasomologus firmus (Izawa, 1986b). However, this structure in these lichomolgid nauplii is lamellate and much feebler and inconspicuous than that of the taeniacanthiforms, so, it might not be a homologous process. Up to now neither such lamellate structure nor caudal process has been reported from nauplii of other lichomolgiforms. The Lichomolgidae and the related families are here referred to as lichomolgiform families, which is equivalent to superfamily Lichomolgoidea Humes \& Stock, 1973, including Sabelliphilidae, Lichomolgidae, Urocopiidae, Pseudanthessiidae, and Rhynchomolgidae.

No caudal process has been discovered so far in other copepods except for a few harpacticoids of the genera Longipedia and Microsetella (Gurney, 1930; Nicholls 1935; Lovegrove, 1956; Faber, 1966; Hirakawa, 1974; Diaz \& Evans, 1983; Koga, 1984; Onbé, 1984). Though the nauplii of Euterpina have a round process at the caudal end, it is uncertain whether or not the structure is a true caudal process. In the nauplii of Longipedia, the process is very prominent, almost as long as the body, at least in the first nauplius stage (Gurney, 1930; Nicholls, 1935; Faber, 1966; Koga, 1984; Onbé, 1984) and never disappears in the naupliar development, except for $L$. weberi. In $L$. weberi, the process degenerates rapidly with stage and disappears completely by the fifth stage (Koga, op. cit.). The process is less prominent and also 

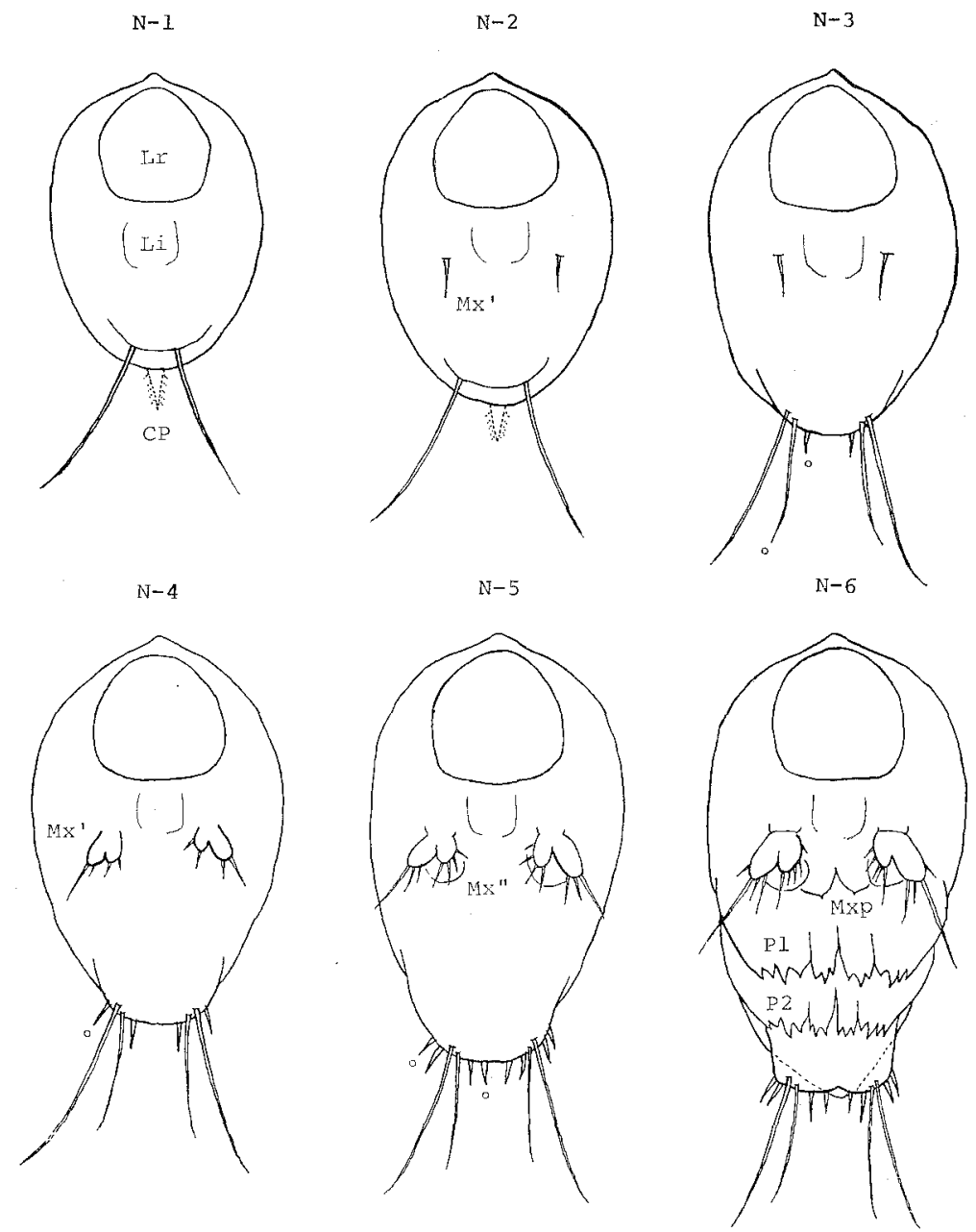

Fig. 2. Changes of the naupliar appendices with stages in Cyclopoida. First three pairs of appendages are not drawn. Abbreviations: Lr, labrum; Li, labium; CP, caudal process; $\mathrm{Mx}^{\prime}$, first maxilla; $\mathrm{Mx}^{\prime \prime}$, second maxilla; Mxp, maxilliped; $\mathrm{P} 1, \mathrm{P} 2$, first and second legs. Small circle indicates added element in the furcal armature.
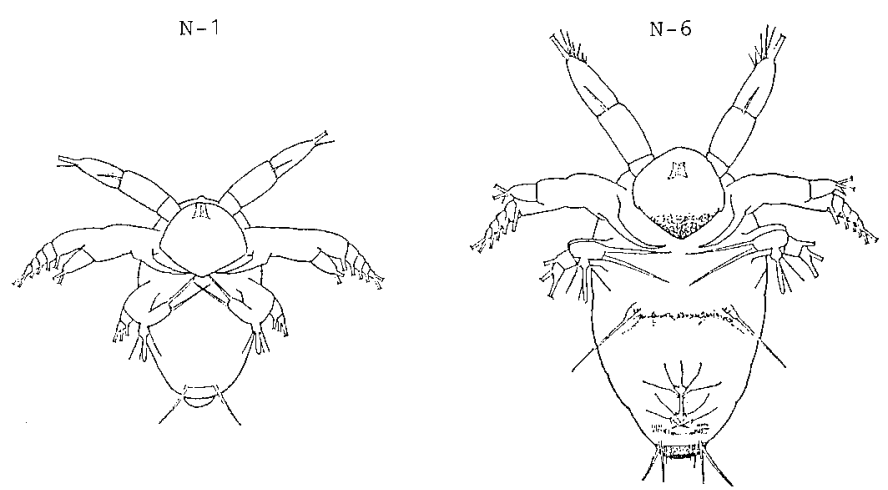

Fig. 3. The first and sixth nauplii of Neoergasilus japonicus (after Urawa et al., 1980a). 
disappears completely in the second or third nauplius stage, as in taeniacanthidiforms, in Microsetella norvegica (Lovegrove, 1956; Hirakawa, 1974; Diaz \& Evans, 1983; Koga, 1984) and Euterpina acutifrons (Tesch, 1915; Haq, 1965b; Koga, op. cit.). At any rate, the caudal process is less prevailing in the extant copepod nauplii. It can be considered that the caudal process found separately in some particular groups of Gyclopoida and Harpacticoida, excluding the uncertain structure in the lichomolgid nauplii, is homologous with the caudal spine characteristic to the nauplii of the Cirripedia (Groom, 1894; Bassindale, 1936; Pyefinch, 1948; \& 1949; Knight-Jones \& Waugh, 1949; Jones \& Crips, 1954; Costlow \& Bookhout, 1958; Barnes \& Barnes, 1959a, b; Barker, 1976; Dalley, 1984; Egan \& Anderson, 1986; Achituv, 1986), terminal process in the Ascothoracida (Lacaze-Duthiers, 1883; Yosii, 1931a, b; Okada, 1938, Grygier, 1985), caudal horn of the nauplius $Y$ of the Facetotecta (Bresciani, 1965; Schram, 1970, 1972; Itô, 1986), and supra-anal process tipped with a seta of the metanauplii of the Mystacocarida (Delamare Deboutteville, 1954; Hessler \& Sanders, 1966). Therefore, the caudal process may be regarded to as a primitive, or a plesiomorphic feature in the Maxillopoda.

As shown diagrammatically in Fig. 2, the paired elements of furcal armature are present as a pair of plumose setae (so-called balancer) in the first two stages and increase to six pairs (two pairs of setae and four pairs of short spines) by the last nauplius stage, which are then taken over by the first copepodid as the elements of caudal rami. The second pair of setae and the first pair of short spines appear in the third stage. The second pair of short spines appear in the fourth stage. The remaining two pairs of short spines are added in the fifth stage to complete the furcal armature. The stage in which the short spines appear, however, is not certain in all species; e.g. the paired elements are completed at the sixth stage in Lichomolgus canui (Costanzo, 1969), at the third of six stages in Pseudomyicola spinosus (Nakamura et al., 1979, as Ps. ostreae), at the fourth of five stages in Neanthessius renicolis (Izawa, 1986b), Ostrincola koe (Kô et al., 1974) and Colobomatus pupa (Izawa, 1975), and at the third of five stages in Panaietis yamagutii (Izawa, 1986b).

A trend of varied reduction in the number and size of the paired elements, except the first pair, is noticed in the yolky nauplii. The second pair of setae are represented by inconspicuous setules in Pseudomyicola spinosus, replaced by spinules in Ostrincola koe, and disappeared entirely in chondracanthid nauplii (Izawa, 1986b). As in these setae, short spines of the furcal armature also decrease in number. Therefore, total number of the paired elements is variable from a complete set of six pairs to only one pair of balancers. The former is represented by the lichomolgids and the others cited previously. Examples of various number of paired elements are: five pairs in Paranthessius anemoniae (Briggs, 1977), Sabellacheres illgi and Gastrodelphys fernaldi (Dudley, 1964), and Praecidochondria setoensis (Izawa, 1986b); four pairs in Neoergasilus japonicus (Urawa et al., 1980a) and Pseudacanthocanthopsis apogonis (Izawa, 1986b); one pair of balancers in Trochicola entericus (Bocuqet et al., 1963), Serioides bocqueti (Carton, 1964) and Gonophysema gullmarensis (Bresciani \& Lützen, 1961). Similar reduction of the furcal armature, especially of short spines, is found in the 
nauplii of free-living poecilostome cyclopoids, too. Both "the early and the oldest nauplii" of Hemicyclops adhaerens reported by Faber (1966, probably fourth and sixth nauplii respectively) have only three pairs of furcal elements, two of setiform and one of spiniform. The furcal armature of the oncaeid and corycaeid nauplii is composed of two pairs of long setae and at most three pairs of spines (Hanaoka, 1952b; Johnson, G., 1969; Björnberg, 1972; Koga, 1984). Number of the furcal elements in these free-living forms is fewer than that of certain symbiotic forms like Lichomolgus and Neanthessius, which are not particularly simplified. Similar phenomena are also found in the nauplii of gnathostome Cyclopoida, there are three pairs in Cyclops scutifer (Elgmork \& Langeland, 1970); four pairs in Oithona similis (Oberg, 1906), $O$. helgolandica and $O$. spinirostris (Gibbons \& Ogilvie, 1933), Cyclops serrulatus and C. leuckarti (Hanaoka, 1944); five pairs in Cyclops fuscus (Hanaoka, op. cit.) and C. strenuus (Dietrich, 1915; Hanaoka, op. cit.); and six pairs in notodelphyids (Dudley, 1966).

It is rather interesting to note that a full-set (six pairs) of furcal armature is retained in the nauplii of semi-parasitic forms such as lichomolgids of poecilostome and notodelphyids of gnathostome, but not in the free-living forms of Cyclopoida. I suspect the full-set condition of furcal armature represents an apomorphy and the incomplete condition in the free-living forms, a plesiomorphy. In my opinion, the paired furcal armature is not a peculiar structure of the nauplius larvae, rather than serving as the forerunners of the caudal rami in the copepodid stages. This assertion will be substantiated with some facts described below. A full-set of paired furcal armature is not found in the nauplii of Oithona, Canuella, or Longipedia, which are generally regarded to as primitive forms. The paired elements do not appear until the second naupliar stage in Longipedia (Gurney, 1930; Nicholls, 1935; Onbé, 1984). And furthermore, the furcal armatures are scarcely found in the nauplii of Cirripedia, Ascothoracida and Facetotecta (see references cited above). However, extreme reduction of the paired furcal armature, which is commonly found in the yolky nauplii of the strictly parasitic forms, seems to be secondary. Incidentally, the furcal armature of the calanoid nauplii is asymmetrical. Such asymmetry seems to be uniuqe to the Calanoida, not only among the Gopepoda, but also in the other maxillopodan taxa. I suppose this is an autapomorphy in the calanoid nauplii.

Among the features of the paired naupliar furcal armature, the followings are some noteworthy characteristics in certain groups of poecilostome Cyclopoida. The third nauplius of Tegobomolochus renicolis (Izawa, 1986b) and proabbly the third and sixth nauplii of Hemicyclops adhaerens (Faber, 1966) have a pair of stout spines, instead of weak ones which are usually found in the other poecilostome cyclopoids. Presence of this pair of stout spines seems to be a characteristic feature shared between the nauplii of the third and later stages in the taeniacanthiform group and Clausidiidae (to which Hemicyclops belongs). It is noteworthy that the furcal armatures of the third, fourth and fifth nauplii of Farranula gracilis (Corycaeidae) have two pairs of strong spines like those in Hemicyclops. However, such spines disappear in the fifth nauplius of $F$. rostrata. The nauplii of these two species of Farranula were described by Björnberg (1972), but their identification might be questionable because they 
were obtained from plankton samples. The nauplii of Oncaeidae and Corycaeidae are peculiar in having two pairs of very long setae, such as in Oncaea venusta these setae exceed the body length (Koga, 1984). Nevertheless, will be mentioned later, these two families do not seem to be particularly related with each other. Hence, this feature shared by them would be the result of a convergent evolution for adaptation to their pelagic life.

\section{2-1-2. The first antenna.}

This uniramous locomotive appendage is usually armed with a sensory hair, or aesthete, and is constructed in the following general pattern. It is basically threesegmented and maintained unchanged throughout the naupliar stages, except for changing setation on the terminal segment. The first segment is short, unarmed and usually indistinctly separated from the body and/or the second segment. Distal two segments are elongate and roughly equal in length. The second segment is basically furnished with three setae on the ventral surface, a basal, a middle, and a terminal, with no additional seta throughout the naupliar development. Setation of the third segment in the nauplii of the poecilostome cyclopoids, excluding ergasilids, can be generalized as follows (see Fig. 4). (For the purpose of comparison, the first antenna of an ergasilid nauplii, Neoergasilus japonicus, is shown in Fig. 5.) The third

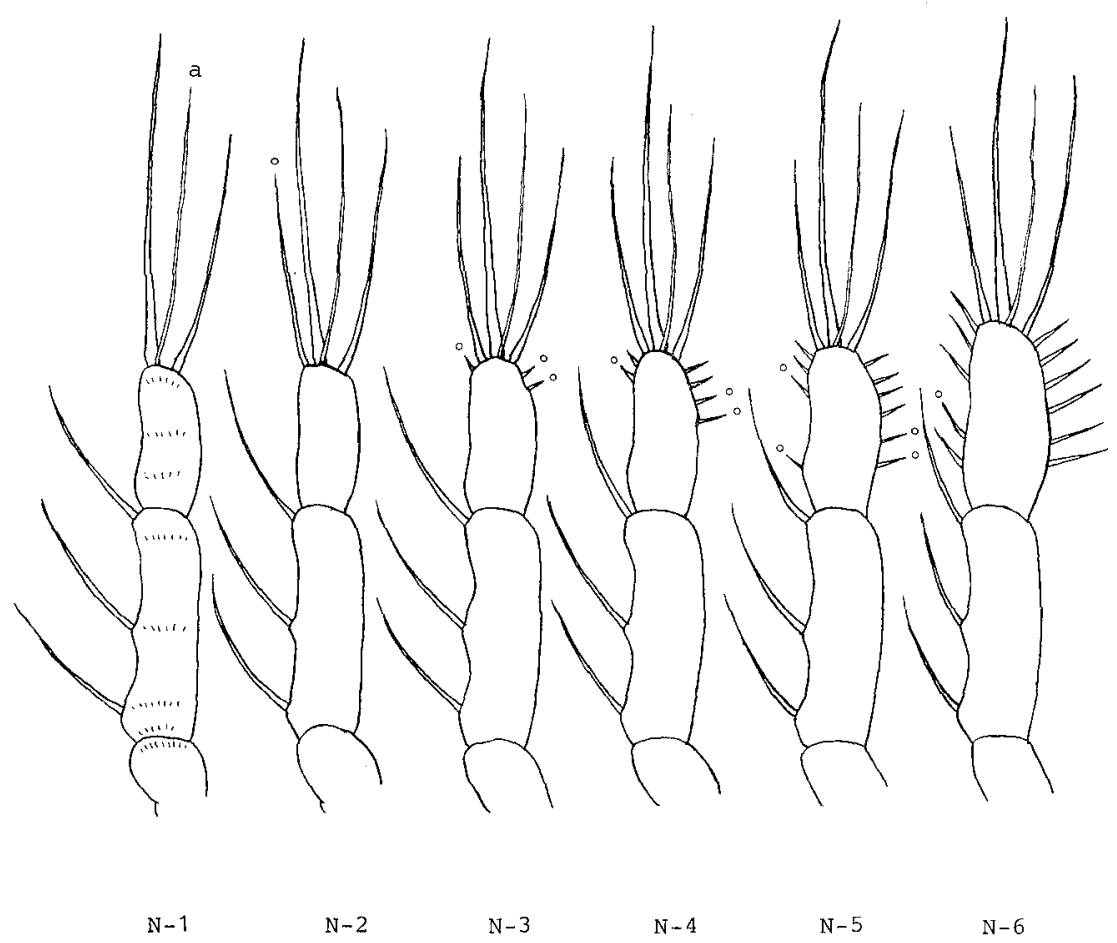

Fig. 4. A generalized segmentation and changes of setation in the naupliar first antennae in the poecilostome Cyclopoida, excluding Ergasilidae. Hairs on the setae are omitted. Small circle indicates a newly added element. Abbreviations: N-1-6, naupliar stages 1-6; a, aesthete. 


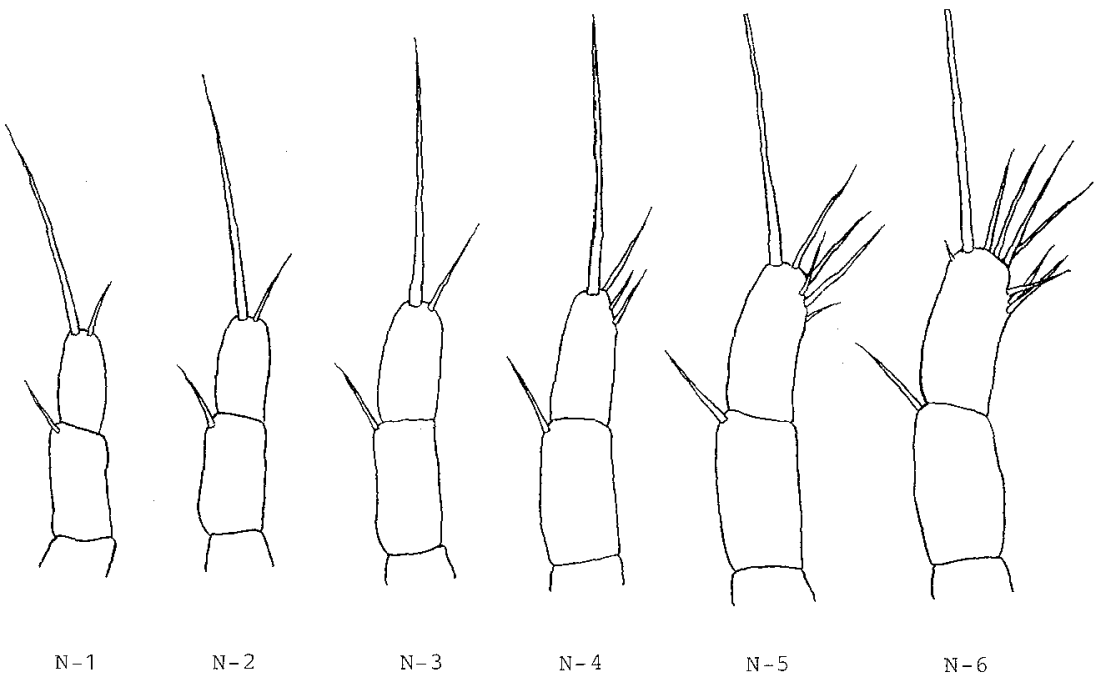

Fig. 5. Segmentation and changes of setation in the ergasilid naupliar first antenna, (Neoergasilus japonicus), with hairs on the longest terminal seta omitted (after Urawa et al., 1980a).

segment in the first stage is fundamentally furnished apically with a long hairy seta accompanied with an aesthete at the base and a slightly shorter seta. A short apical seta is added in the second stage, and in the succeeding stages a maximum of five and six short spines are added, respectively, on the ventral and dorsal faces. These short spines may grow longer as the nauplius develops further.

In the pelagic copepod nauplii, the second segment is clearly definable into three sections, based on Oberg's (1906) work. He noticed that the second segment of the naupliar first antenna is fundamentally composed of three sections with each bearing a seta. He considered that these three naupliar segments in the pelagic copepods, or his "Wibel, Schaft und Blatt", were finally divided into 7, 11, and 7 segments, respectively, in the copepodid stage. The feature in Longipedia americana (Harpacticoida) is noteworthy in this respect. The three-segmented condition with each carrying a seta is complete at the first stage and, therefore, the first antenna is said to be five-segmented (Onbé, 1984). Hanaoka (1952a) divided the second antennular segment of various free-living copepod nauplii into seven types based on the manner of its division; they are, 1) without any division, 2) with rudimentary division(s), 3) only the first division is distinguished by a suture, 4) the first division fuses to the first segment, 5) only the third division is distinguished by a suture, 6) three divisions are distinguishable, 7) a portion of the first two divisions fuses to the first segment to form a long segment. Furthermore, he also noted that difference in setation of the second segment, such as equally long three setae, only one seta, etc. The naupliar first antenna of the semi-parasitic or less specialized parasitic poecilostome cyclopoids are almost entirely preferable to Hanaoka's type 1) or 2) with the exception of Lichomolgus canui reported by Costanzo (1969), Paranthessius anemoniae by Briggs (1977) and Serioides bocqueti by Carton (1964), which fall under the type 
3) or 4). In those highly specialized parasitic forms, such as Sarcotaces pacificus (Izawa, 1973), Mesoglicola delagei (Quidor, 1922; Taton, 1934), Gonophysema gullmarensis (Bresciani \& Lützen, 1961), all three or the distal two segments of the first antenna are fused nearly completely into a rod-like segment, which is usually the case in the strictly parasitic forms, namely, Caligoida and Lernaeopodoida.

The first antenna of a typical calanoid nauplius is comparatively large and characteristic in having a broad or long distal segment (see Oberg, 1906; Lebour, 1916; Gurney, 1934a; Campbell, 1934; Johnson, 1934a, b, 1935, 1937, 1948, 1965, 1966; Humes, 1955; Koga, 1960b, 1968, 1984; Comita \& Tommerdahl, 1960; Gaudy, 1961; Ummerkutty, 1964; Matthews, 1964; Shen \& Chang, 1965; Björnberg, 1966, 1972; Grice, 1969; Lawson \& Grice, 1970; Uye \& Onbé, 1975; Reddy \& Devi, 1985).

It seems that the one- or two-segmented conditions of the first antenna are formed due to the degeneration of joint(s), as these oilgomerous first antennae are present exclusively in the yolky nauplii of the totally parasitic forms. Though it is difficult to judge whether the usual three-segmented first antenna is primitive or the five-segmented one as in Longipedia americana, I consider here that the three-segmented condition is plesiomorphic in the extant copepod nauplii. The naupliar first antenna of Phyllodicola petiti is unusually three-segmented (Laubier, 1961); its third segment has two apical setae as in usual form, but the first segment is markedly elongate and bears three setae, the distal two segments are very short, and the second segment has no seta. These unusual features can be interpreted as resulted from the separation of the original third segment and fusion of the proximal two segments.

Setation of the second segment can vary from the maximum three setae to zero with respect to species. A trend of losing the proximal and middle setae in this segment is found usually in the nauplii of poecilostome Cyclopoida. This is particularly true for the middle seta, it seems to disappear first. These two setae decrease in size as development proceeds in Pseudomyicola spinosus (Nakamura et al., 1979) and Ostrincola koe (Kô et al., 1974). The middle seta disappears completely by the last stage in Pseudacanthocanthopsis apogonis and Praecidochondria setoensis (Izawa, 1986b). But these two setae never appear and the segment has only the distal seta in Mytilicola intestinalis (Pesta, 1907; Costanzo, 1959), Sarcotaces pacificus (Izawa, 1973), Colobomatus pupa (Izawa, 1975) and probably throughout the Ergasilidac (Wilson, 1911; Gurney, 1913; Halisch, 1940; Yin, 1957; Zmerzlaya, 1972; Mirzoeva, 1973; Urawa et al., 1980a; Ben Hassine, 1983; Wilson's metanauplii and Gurney's late nauplii are not ergaslids, as it will be mentioned later). The naupliar first antenna of Mesoglicola delagei, whose systematic position is still problematic (see Bowman \& Abele, 1982) though it has been accommodated in Antheacheridae, loses the middle seta as in chondracanthid (Taton, 1934). In the nauplii of Herpyllobius arcticus, H. polynoes and Eurysilenium truncatum (Lützen, 1968) (Herpyllobiidae), all three setae of the second segment are lost. In the nauplius of Gonophysema gullmarensis (Bresciani \& Lützen, 1961a), the original middle and distal setae of the second segment are lost. This type of setation seems to be peculiar as far as I know. The nauplius of Aphanodomus 
terebellae (Xenocoelomidae) does not appear simplified and its first antenna is furnished with three setae on the second segment, though the adult is much specialized (Bresciani \& Lützen, 1974). However, due to the scarcity of information it is difficult to relate the setation of the second segment with the copepod lineages at the present time.

As shown in Fig. 5, setation of the first antenna of the ergasilid nauplii distinctly differs from the generalized one in the following three points: 1) the second segment has only the distal seta, 2) almost all the short spines on the third segment aggregate on its dorsodistal portion, and 3) there is no aesthete on the third segment. The presence of only the distal seta on the second segment is also found in some other strictly parasitic forms, like Mytilicola whose naupliar stages are extremely reduced. With respect to the naupliar development, the ergasilids are quite different from the other strictly parasitic forms, like Mytilicola, in exhibiting no tendency toward reduction of naupliar stages (see Urawa et al., 1980a). The peculiar arrangement of the short spines on the third segment resembles those in the Gastrodelphyidae (poecilostome Cyclopoida) (Dudley, 1964), Lernaeidae and Notodelphyidae (gnathostome Cyclopoida) (Grabda, 1963; Wilson, 1918; Sproston et al., 1950). Possession of an aesthete arising from the base of an apical seta seems to be universal among the copepod nauplii, but it is often overlooked or confused with an usual seta in the works of old days.

As to the shape of the aesthete, at least two different types are noticed: a setiform aesthete almost as long as the seta from which it arises (this type of aesthete is easily confused with the usual seta) and a filiform or string-like element which is clearly shorter than the seta from which it arises. In many old works three or two apical setae were often mentioned or illustrated for the first naupliar stage. It is very likely that in the former case, one of the three setae was probably a setiform aesthete, and in the latter case, it is highly probable that a filiform aesthete was overlooked.

Of the nauplii studied by me, the setiform aesthete is found in Taeniacanthus lagocephali (Izawa, 1986a), Taeniastrotos pleuronichthydis (=Anchistrotos pleuronichthydis), Tegobomolochus nasicola, Doridicola sepiae, Nasomolgus firmus, Philoblenna arabici, Neanthessius renicolis, and Panaietis yamagutii (Izawa, 1986b), while the filiform aesthete is found in Sarcotaces pacificus (Izawa, 1973), Colobomatus pupa (Izawa, 1975), Pseudacanthocanthopsis apogonis and Praecidochondria setoensis (Izawa, 1986b). The aesthete type is occasionally different even in closely related families; for instance, Neanthessius and Panaietis have setiform aesthete, and Ostrincola koe (Kô et al., 1974) has filiform one. Neanthessius and Panaietis were formerly placed in the Myicolidae together with Ostrincola but now Humes (1986) transferred them to the Anthessiidae. I suppose Pseudomyicola spinosus (Myicolidae) has filiform aesthete, though only two apical setae are illustrated in the first nauplius stage by Nakamura et al., (1979). Dudley's (1964, 1966) reports indicate the presence of filiform aesthete in Gastrodelphyidae (poecilostome Gyclopoida) and Notodelphyidae (gnathostome Cyclopoida). Thus, it may be assumed that the nauplii of Calanoida and Harpacticoida are furnished with a setiform aesthete with variable length and shape with species (sce Oberg 1906; 
Dietrich, 1915; Haq, 1965b; Grice, 1969; Lauson \& Grice, 1970; Itô \& Takashio, 1981). Judging from the species cited above and found in literatures, it is conceivable that the filiform type of aesthete is derived from the setiform type through degeneration, since the setiform type is common in the less simplified nauplii and the filiform type in the well simplified nauplii.

There are a few descriptions of naupliar setation that are different from the above mentioned general form (two setae and an aesthete in the first nauplius stage, three setac and an aesthete in succeeding stages). Of the seven species studied by Oberg (1906), Pseudocalanus elongatus was reported to have four apical elements including an aesthete throughout all the nauplius stages. Of the 34 species studied by Björnberg (1972), the nauplii of Oithona oculata, Corycaeus amazonica, and Oncaea media were reported to have four apical elements in the first nauplius stage, though three elements were illustrated on the right first antenna in the last species (one of these apical elements is probably an aesthete). Furthermore, Humes (1955) described that the nauplii of Epischura massachusettsensis carried three plumose apical setae in the first nauplius stage, and added a small aesthete in the second stage. Also in Lichomolgus canui, Costanzo (1969) showed that the first antenna with three plumose setae at the tip in the first nauplius stage and adding an aesthete in the second stage. If all of these are correct, the number of apical elements including an aesthete in the first antenna of the first nauplius stage may vary from three to four with respect to species. At any rate, a precise examination of setation in various nauplii is needed to resolve this kind of problem.

Within the Maxillopoda, the number of segments of the naupliar first antenna can be different from group to group or even within the group. However, a curious concordance is found in some characteristics of their setation. As mentioned above, the second segment of the copepod nauplii has three prominent setae, a set of similar setae is also found in other maxillopodans and, in fact, even in the Cephalocarida (Fig. 6). Some typical examples are shown below. In nauplius Y, type I of the Facetotecta (Itô, 1986), the third segment has three setae on the inner (ventral) face (Fig. 6B). In Baccalaureus japonicus (Ascothoraicda), the first antenna, which consists of four segments, bears one prominent ventral seta in each of the first three segments (Fig. 6D). The first antenna of most ascothoracid nauplii is represented by a single rod-shaped segment (see Grygier, 1985); nevertheless, the three prominent ventral setae are present (Fig. 6C). In Conchoderma auritum (Cirripedia) the three setae on the first antenna, which consists of four segments at the second stage (Dalley, 1984), are distributed differently with the proximal one arising from the second segment and the other two, from the third segment (Fig. 6E). In the Mystacocarida, "the stage I nauplius" of Derocheilocaris typicus (Hessler \& Sanders, 1966), has three groups of setae which seem to correspond with the three setae in question. Its antenna is eight-segmented, with three setae on the third, one seta on the fifth, and four setae on the seventh segments (Fig. 6G). In the Cephalocarida, the metanauplius of Lightiella incisa (Sanders \& Hessler, 1963) has three groups of setae which also correspond with the three setae in question. Its antenna is six-segmented, with two 


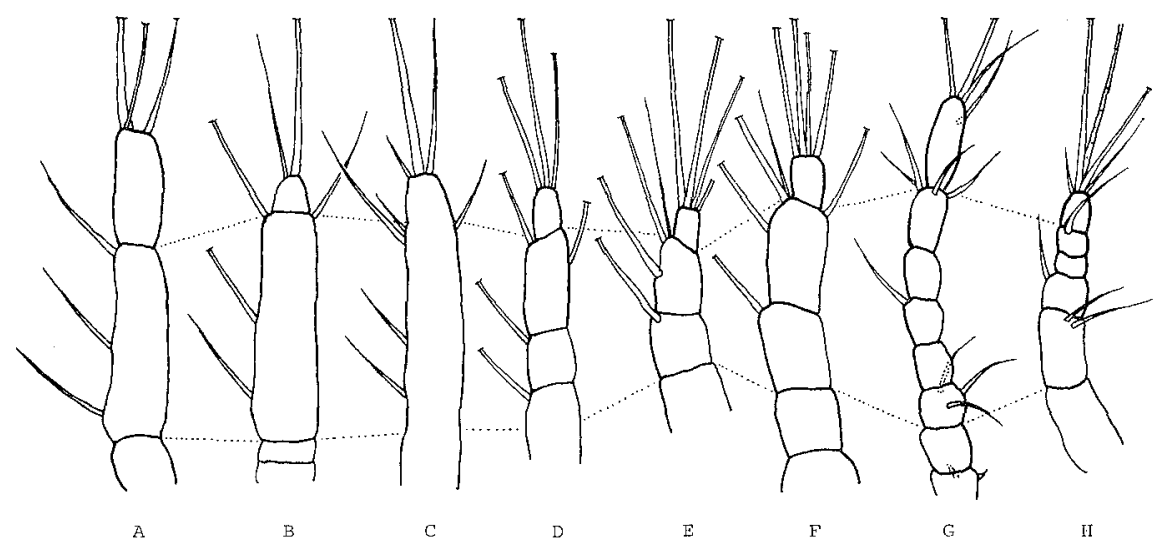

Fig. 6. Homologies of segmentation and setation of the naupliar first antenna in the Copepoda (A, generalized form in the poecilostome Cyclopoida described in previous section); Facetotecta (B, nauplius y, Pacific type I, after Itô, 1986); Ascothoracida (C, generalized form in laurid, after Grygier, 1987; D, Baccalaureus japonicus, after Yosii, 1931b); Cirripedia (E. second nauplius of Conchoderma auritum; F, third nauplius of the same, after Dalley, 1984); Mystacocarida (G, Derocheilocaris typicus, after Hessler \& Sanders, 1966); Cephalocarida (H, Lightiella incisa, after Sanders \& Hessler, 1963).

setae on the second, one seta each on the third and fifth segments (Fig. 6H). Therefore, the counterparts of these three setae in copepod first antenna can also be found in those crustaceans with different number of segments. Moreover, there are other features in common. Facetotecta has a stea on the distodorsal end of the penultimate segment (Fig. 6B), the identical element is found on the penultimate segment in the Conchoderma nauplii in the stages later than the third stage (Fig. 6F) (Dalley, op. cit.), and a possibly identical element is represented by a subapical dorsal seta in the Ascothoracida (Fig. 6C, D). In Ascothoracida and Cirripedia, the distal most element of the three prominent setae is accompanied by a setule near its base (Fig. $6 \mathrm{C}, \mathrm{E}, \mathrm{F})$. Thus, these nauplii seem to be closely related with each other in this respect. In the Mystacocarida, the penultimate segment is setose and resembles those found in the Cirripedia and Ascothoracida, though the actual homology of each seta is still uncertain (Fig. 6G, H). The similarity in these subapical armatures seems to indicate a homology in, at least, the penultimate segment of the naupliar first antennae, irrespective of the difference in segmentation.

Without exception, the third segment in the Copepoda corresponds to the terminal segment of the other groups shown in Fig. 6.

\section{2-1-3. Second antenna.}

This biramous appendage is a locomotive and feeding organ. It consists of a two-segmented protopod, an one-segmented endopod and a five-segmented exopod consistently throughout the naupliar stages in the poecilostome Cyclopoida, though first exopodal segment which is markedly longer than others, is divided in the later stages of some non-ergasilid forms. The fundamental structure of the second antennae in the nauplii of the poecilostome Cyclopoida, except for the Ergasilidae, and the 


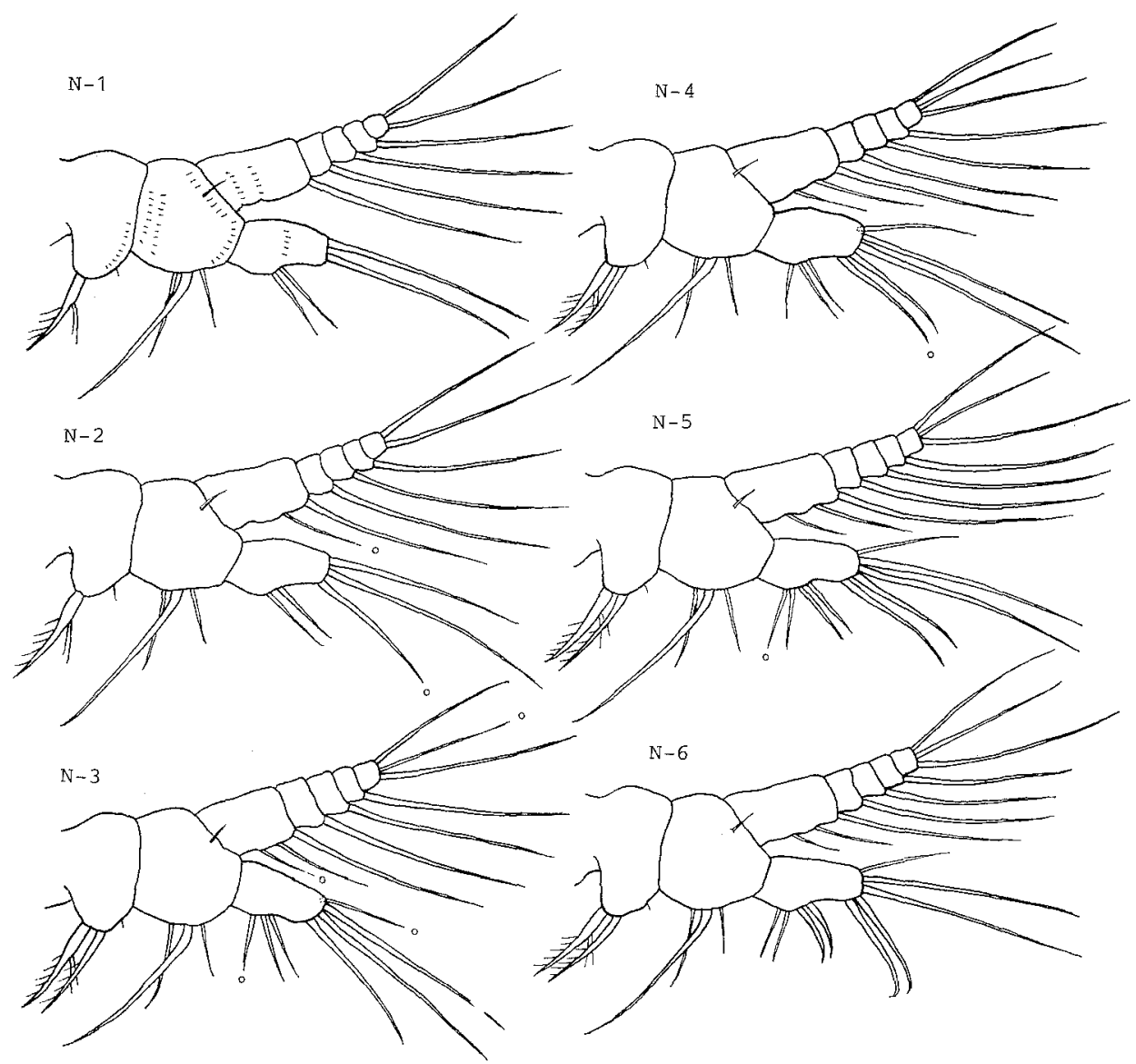

Fig. 7. Generalized morphological changes of the naupliar second antenna in the poecilostome Cyclopoida, excluding Ergasilidae. Hairs on the setae are omitted. Small circle indicates newly added element.
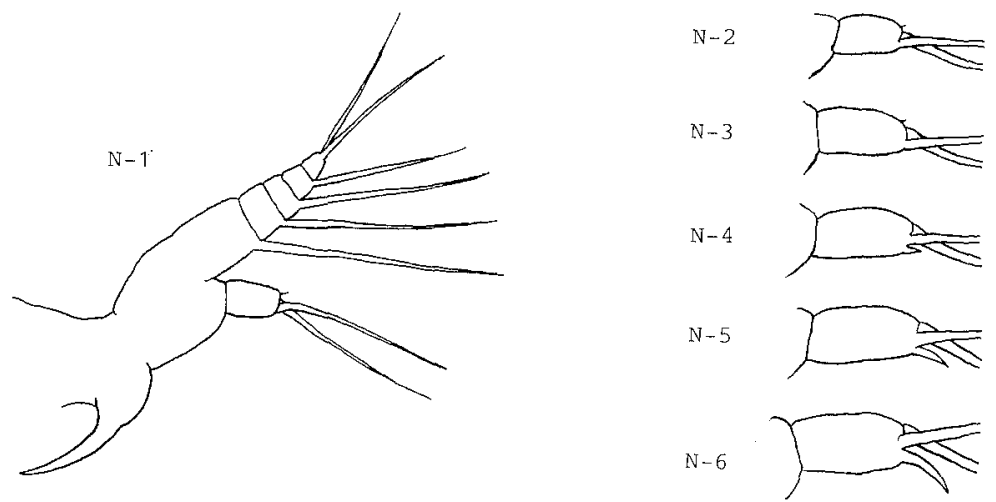

Fig. 8. The second antenna of the first nauplius and the endopods of the naupliar stages 2-6 in the Ergasilidae, Neoergasilus japonicus (after Urawa et al., 1980a). There is no significant change during the naupliar stages, except for a claw on the endopod. 
change of their ornamentation with stages can be generalized as illustrated in Fig. 7. The second antennae of the ergasilid nauplii are shown in Fig. 8; in which the segmentation is unaltered throughout the naupliar stages. For comparison with other gnathostome copepods, the second antennae of the first and the later nauplii of Oithona nana (gnathostome Cyclopoida), Epischura massachusettsensis (Calanoida),

\section{A Oithna nana}

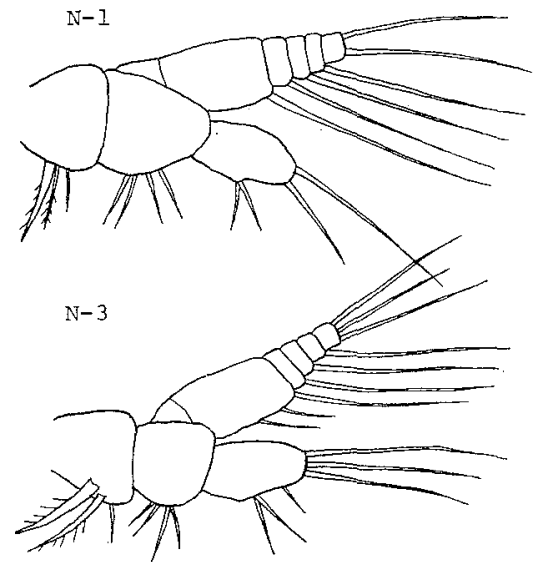

$\mathrm{C}$
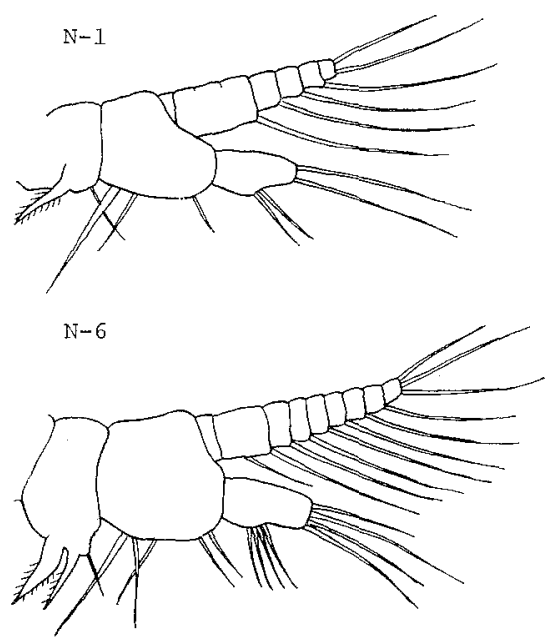

B Epischura massachusettsensis

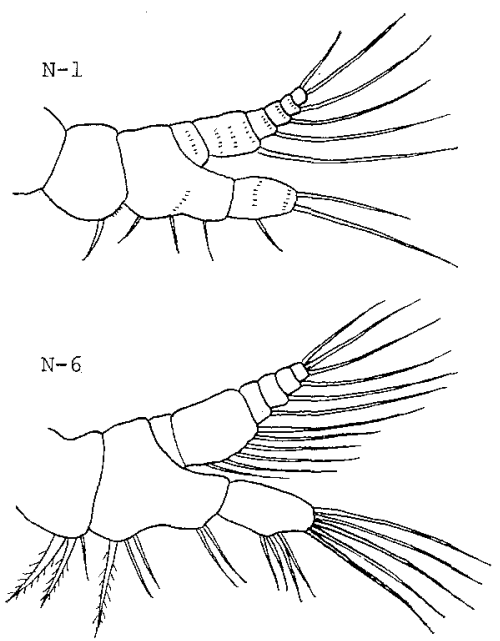

Disbe furcata
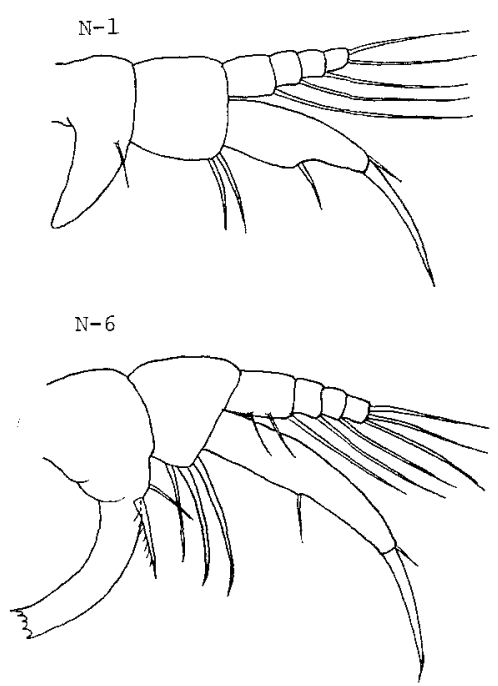

Fig. 9. Naupliar second antenna in the gnathostome Gyclopoida (A), Calanoida (B), and Harpacticoida (C \& D). A, Oithona nana (after Haq, 1965, as Oithonina nana); B, Epischura massachusettsensis (after Humes, 1955); G, Longipedia coronata, (after Nicholls, 1935); D, Tisbe furcata, (after Johnson \& Olson, 1948). 
and Longipedia coronata and Tisbe furcata (Harpacticoida) are given in Fig. 9.

The short coxa bears a stout spine at the tip of its medial expansion and a minute accessory spine on the medio-distal margin of the first and second stages. An additional coxal spine appears in the third stage, though ergasilids are provided with no such additional one. Appearance of the additional coxal spine at the third nauplius stage can be found in Lichomolgus canui (Costanzo, 1969), Oncaea mediterranea (Hanaoka, 1952b), O. media (Björnberg, 1972), O. venusta (Koga, 1984), and Corycaeus anglicus (Johnson, G., 1969). These coxal spines together with spines on the basis and endopod seem to be concerned with feeding. The coxal spine(s) of the feeding nauplii is usually furnished with a row of sparse hairs along the inner side and two hairs on the opposite side as seen in Taeniacanthus lagocephali (Izawa, 1986a) and Doridicola sepiae (Izawa, 1986b).

Possession of two coxal spines on the second antenna after the third naupliar stage seems to be a common and fundamental feature for Copepoda, because it is also found in other copepods such as Calanoida, Harpacticoida and gnathostome Cyclopoida (Fig. 9). However, the second antenna of the ergasilid nauplii is distinct from the generalized one in having a strong claw-like spine on the coxa throughout all the stages (Fig. 8). The nauplii of ergasilids after the third stage are known in Ergasilus centrarchidarum (Wilson, 1911), E. minor (Halisch, 1940), E. sieboldi (Zmerzlaya, 1972), Thersitina gasterostei (Gurney, 1913), Sinergasilus major (Yin, 1957), S. lieni (Mirzoeva, 1973), Neoergasilus japonicus (Urawa et al., 1980a), and E. lizae (Ben Hassine, 1983). The additional spine of coxa is, however, described only by Wilson and Gurney in their species, in which the spine appears in the fourth stage instead. In other ergasilids, the coxa bears only one spine throughout the naupliar stages, which is heavy and naked, and is usually called "masticatory spine" (see Kabata, 1976; Urawa et al., op. cit.; Zmerzlaya, op. cit.; Mirzoeva, op. cit.). These features seem to be characteristic to the nauplii of the Ergasilidae. Incidentally, the metanauplii of E. centrarchidarum reported by Wilson (1911) and the "later nauplii" (fourth nauplius) of $T$. gasterostei by Gurney (1913) do not belong to ergasilids.

There is little doubt that the coxal spines are unnecessary for lecithotrophic nauplii. Indeed, the coxa of the second antenna is naked almost completely throughout all the stages in the majority of lecithotrophic nauplii, such as seen in Ostrincola koe (Kô et al., 1974), Pseudomyicola spinosus (Nakamura et al., 1979), Neanthessius renicolis, Panaietis yamagutii (Izawa, 1986b), Mytilicola intestinalis (Pesta, 1907; Costanzo, 1959), Trochicola entericus (Bocquet et al., 1963), Gastrodelphys fernaldi and Sabellacheres illgi (Dudley, 1964), Selioides bocqueti (Carton, 1964), Sarcotaces pacificus (Izawa, 1973), Colobomatus pupa (Izawa, 1975), Pseudacanthocanthopsis apogonis, and Praecidochondria setoensis (Izawa, 1986b). This phenomenon is more common in specialized parasitic forms.

In some calanoids, the coxal armature is degenerated: For example, only one coxal spine is present throughout the nauplius stages in Centropages typicus (Lawson \& Grice, 1970), Tortanus discaudatus (Johnson, 1934a), Acartia longiremis (Oberg, 1906), A. clausi and A. tonsa (Conover, 1956), Labidocera bengalensis and Pseudodiaptomus 
aurivilli (Ummerkutty, 1964), and Rhincalanus nasutus (Gurney, 1934a); no coxal spine appears at all throughout the naupliar stages of Euchaeta japonicus (Campbell, 1934; Lewis \& Ramnarine, 1969), E. norvegica (Nicholls, 1934), E. marina and Candacia armata (Bernard, 1964), Pareuchaeta russelli (Koga, 1960a), Chiridius armatus and Xanthocalanus fallax (Matthews, 1964). All these nauplii are hatched from large eggs and apparently non-feeding since their mandibles are also degenerative.

In the Harpacticoida, the basic structure of the coxa is retained in the nauplii of Longipedia (Fig. 9C) and Canuella but not in most harpacticoids. In Longipedia, the feeding apparatus of coxa is basically the same as that in the Cyclopoida and Calanoida in having two moderately developed, hairy spines and another accessory small spine (see Gurney, 1930; Nicholls, 1935; Vincx \& Heip, 1979; Onbé, 1984). In contrast to Longipedia, the corresponding part in Tisbe furcata (Fig. 9D) is remarkably deformed, though the two elements are retained; the coxal spine is represented by a stout process in the first stage and develops in the later stages into a toothed strong process called "gnathobase", to which the other elements, a spine and an accessory small spine, are attached (see Fraser, 1936; Johnson \& Olson, 1948; Krishnaswamy, 1955; Bresciani, 1960; Ummerkutty, 1960; El-Maghraby, 1964; Haq, 1965b; Itô, 1970, 1975; Itô \& Takashio, 1981; Carter \& Bradford, 1972; Schminke, 1982; Diaz \& Evans, 1983; Bourguet, 1986). Such coxal armature with gnathobase as in Tisbe is common among other harpacticoids.

The basis protrudes distally at the base of the endopod beyond the level, where the exopod attaches. In the poecilostome Cyclopoida, except for the Ergasilidae, the basis is usually furnished with a set of spines, a long spine and two short spines, about the middle of the medial margin. In some cases, another short seta is found on the anterior surface. This setation is almost unaltered throughout the naupliar stages (Fig. 7) and resemble with that in the gnathostome Cyclopoida (Fig. 9A). In Calanoida (Fig. 9B) and Longipedia (Fig. 9C), the basis is furnished with two sets of armature on the medial margin on the proximal and distally. The proximal set of armature includes one long spine. Since this long spine is regarded as the counterpart of the long spine in the poecilostome Cyclopoida, the single set of spines of the Gyclopoida can be considered corresponding to the proximal set of spines in the Calanoida and Longipedia. If this is correct, the distal set of spines is wanting in the Gyclopoida. In this respect I consider the basis of the naupliar second antenna incorporates the first endopodal segment of the copepodid. This notion is supported by many instances where the basal protrusion is demarcated from the basis proper during the naupliar stages.

The second antenna of the ergasilid nauplii (Fig. 8) is distinct from the generalized one in having a naked basis, except two dubious forms reported respectively by Wilson (1911) and Gurney (1919). Wilson's (op. cit.) metanauplii of E. centrarchidarum have the basis armed with two or three spines, but Gurney (op. cit.) did not refer to this point in his latter nauplii of $T$. gasterostei.

One of the spines on the medial margin of the basis is extremely elongated in Taeniacanthus lagocephali (Izawa, 1986a), Taeniastrotos pleuronichthydis (=Anchistrotos) 
and Tegobomolochus nasicola (Izawa, 1986b), and Hemicyclops adhaerens (Faber, 1966). Possession of this extremely long spines is confirmed in the nauplii of all other taeniacanthiforms studied by Izawa (unpublished). A long spine is also found in Oncaea media (Björnberg, 1972; Malt, 1982) and O. subtilis (Malt op. cit.), though it is not as long as in the formers.

These spines on the medial margin of the basis usually take part in feeding. However, extremely long one as in taeniacanthiforms are too long for this function. At any rate, these extremely long spines are useful character for identifying the nauplii of the taeniacanthiform group (and probably Clausidiidae including Hemicyclops, and Oncaeidac). Faber (op. cit., p. 199) has pointed out the significance of this long spine when he stated that "a diagnostic feature evident on all nauplii examined".

In the yolky nauplii, the basis is slim and its spines are reduced in size as exemplified in Neanthessius renicolis and Panaietis yamagutii (Izawa, 1986b), Ostrincola koe (Kô et al., 1974) and Pseudomyicola spinosus (Nakamura et al., 1979). Slimmer and almost naked basis is also found in other yolky nauplii, such as in Mytilicola intestinalis (Pesta, 1907; Costanzo, 1959), Trochicola entericus (Bocquet et al., 1963), Sarcotaces pacificus (Izawa, 1973), Colobomatus pupa (Izawa, 1975), Gastrodelphyid fernaldi and Sabellacheres illgi (Dudley, 1964), Pseudacanthocanthopsis apogonis and Praecidochondria setoensis (Izawa, 1986b).

The endopod is one-segmented. It is furnished with two sets of ornaments consisting of two medial short spines on the medial margin and two apical setae in the first stage. The level of the medial spines, where the endopod decreases in width, corresponds to the distal border of the penultimate segment of the second antenna of the first copepodite. In the succeeding stages, five elements are added probably in the following order (Fig. 7): a seta-like spine appears at the mediodistal corner in the second stage, a short spine and a weak seta appear at the middle of the medial margin and the outer-distal corner respectively in the third stage, a setiform spine appears at the medio-distal corner in the fourth stage, and a short spine is added at the middle of the medial margin in the fifth stage. Some of the spines become stout by the last stage in those species with claw(s) on the second antenna in the first copepodid stage. For example, in Ostrincola koe (Myicolidae), whose first copepodid has a claw on the terminal segment, one spine on the distal margin of the naupliar endopod develops into a claw-like element (Kô, 1969; Kô et al., 1974). In Neanthessius renicolis and Panaietis yamagutii (Anthessiidae), whose first copepodid has two claws on the terminal segment, two spines on the distal margin of the naupliar endopod develops into claw-like elements (Izawa, 1986b). In the Philichthyidae, Sarcotacidae and Chondracanthidae, whose first copepodid has one and two claws respectively on the penultimate and terminal segments, one middle and two distal spines of the naupliar endopod grow stouter, this is found in Colobomatus pupa (Izawa, 1975), Sarcotaces pacificus (Izawa, 1973), and Pseudacanthocanthopsis apogonis and Praecidochondria setoensis (Izawa, 1986b). Furthermore, in the species which is furnished with a sole strong terminal claw on the copepodid second antenna, such as Mytilicola intestinalis, 
Trochicola enterricus (Mytilicolidae) and Neoergasilus japonicus (Ergasilidae) (Fig. 8), only one spine appears in the mediodistal corner of the naupliar endopod in the last stage (Pesta, 1907; Bocquet et al., 1963; Urawa et al., 1980a). Similar phenomenon is also found in the other groups within the Copepoda; e.g. Cancerilla tubulata of the siphonostome Gyclopoida (Carton, 1968; Changeux, 1957; Stock et al., 1963), and Caligus spinosus of the Caligoida (Izawa, 1969).

In the Girripedia (Fig. 10), the endopod is three-segmented, though the distal joint is indistinct in most cases (see Groom, 1894; Bassindale, 1936; Pyefinch, 1948, 1949; Knight-Jones \& Waugh, 1949; Jones \& Crips, 1954; Costlow \& Bookhout, 1958; Barnes \& Barnes, 1959a, b; Barker, 1976; Dalley, 1984; Egan \& Anderson, 1986). In the Ascothoracida, the endopod is also three-segmented, such as in Baccalaureus japonicus (Fig. 10) (see Yosii, 1931b) and an unclassified metanauplius studied by Grygier (1985, 1987). However in most ascothoracids these segments tend to fuse into an elongate segment armed with three sets of setae (see Grygier, op. cit.). In the Mystacocarida (Fig. 10), three-segmented structure is distinct and the third segment has an unique, strong process at the tip (Hessler \& Sanders, 1966; DelamareDeboutteville, 1954 considered it to be four-segmented by recognizing the terminal claw as a segment). The endopod is two-segmented in the Facetotecta nauplius $y$ (Bresciani, 1965; Schram, 1970, 1972; Itô, 1985, 1986) and Cephalocarida (Sanders, 1963; Sanders \& Hessler, 1963) (Fig. 10).

As shown in Fig. 7, the generalized exopod of the poecilostome Cyclopoida is five-segmented in the first nauplius stage. The first segment is the longest, almost as long as the remaining four segments combined. Each of the proximal four segments is furnished with a plumose medial seta each at the distal end and the terminal segment is tipped with two plumose setae. On the terminal segment, a seta or setule is added between the two apical setae in the third stage. The first segment is added with one medial setule at the second and third stages, and two slight constrictions appear at the bases of these additional setules. With these constrictions the segment is divisible into three annuli. From the facts that will be mentioned below, these annuli with a seta on each are regarded as rudimentary segments. Such rudimentary segmentation is distinct in Lichomolgus canui (Costanzo, 1969), Oncaea mediterranea (Hanaoka, 1952b), Corycaeus angulicus (Johnson, 1969), and Tegobomolochus nasicola, Philoblenna arabici and Panaietis yamagutii (Izawa, 1986b). In the free-living poecilostome Cyclopoida, the first exopod segment is divisible into distinct segments in the later naupliar stage. In Oncaea mediterranea, the exopod is five-segmented in the third and fourth nauplius, but six-segmented in the sixth naupliar stage (Hanaoka, 1952b). In Oncaea venusta, Corycaeus affinis, C. pacificus and C. speciosus, the sixsegmented exopod (considering the short and naked basal annulus of the first part as a segment) in the first nauplius stage becomes seven-segmented in the succeeding stages (Koga, 1984).

In the ergasilid nauplii studied thus far, except for the two dubious forms reported by Wilson (1911) and Gurney (1913), the exopod is five-segmented and has no additional seta nor annulus representing a rudimentary segment throughout the 

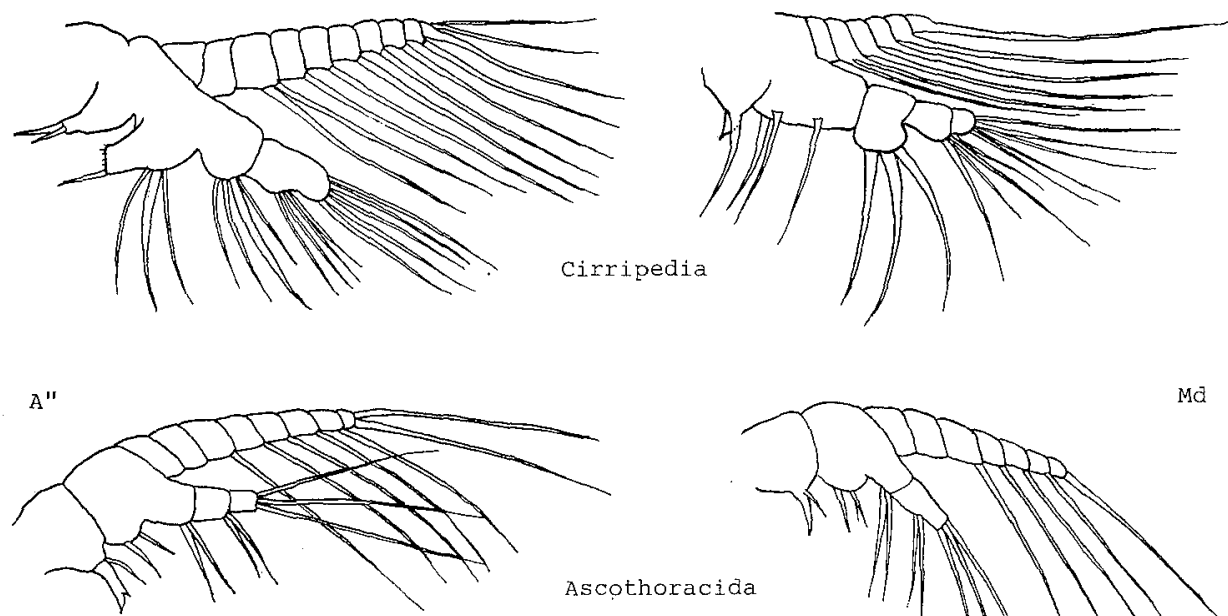

Ascothoracida
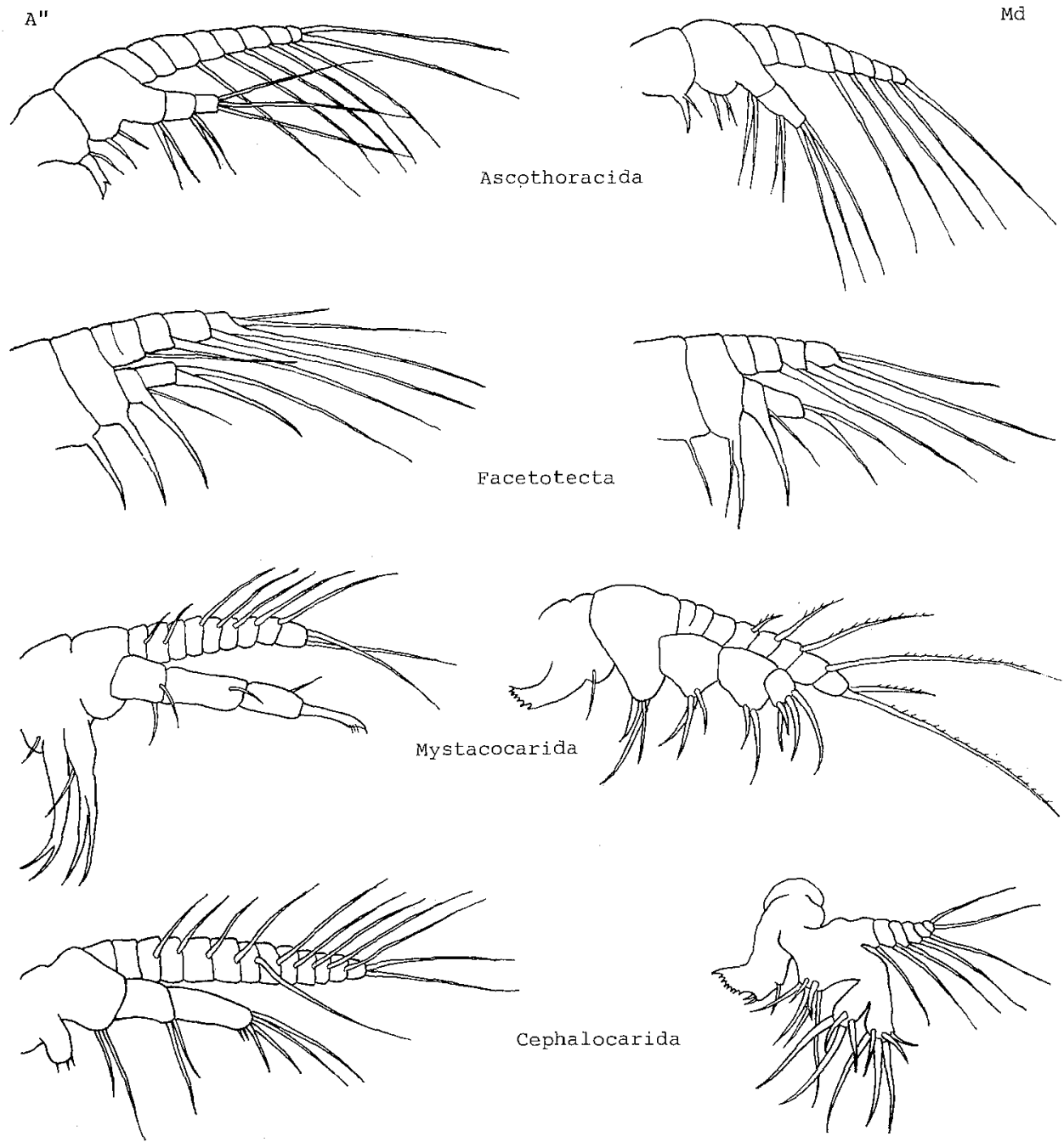

Fig. 10. Naupliar second antenna (left) and mandible (right) in the Cirripedia (Chthamalus stellatus, after Bassindale, 1936), Ascothoracida (Baccalaureus japonicus, after Yosii, 1931b), Facetotecta (nauplius y, Pacific Type I, after Itô, 1986), Mystacocarida (Derocheilocaris typicus. after Hessier \& Sanders, 1966), and Cephalocarida (Hutchinsoniella macracantha, after Sanders, 1963). 
naupliar stages, this is represented in Fig. 8 by Neoergasilus japonicus (Urawa et al., 1980a).

As shown in Fig. 9, the exopod of the gnathostome Cyclopoida, Calanoida, and Canuella and Longipedia of Harpacticoida is composed of six segments in the first stage. Their first segments are short and naked.

In the nauplii of some parasitic forms, the exopod decreases in the number of segments. It is four segments in Gastrodelphys fernaldi and Sabellacheres illgi (Dudley, 1964) and Mytilicola entericus (Pesta, 1907; Costanzo, 1959), Selioides bocqueti (Carton, 1964), Aphanodomus terebellae (Bresciani \& Lützen, 1974), and Eurysilenium truncatum and probably Herpyllobius arcticus and $H$. polynoes (Lützen, 1968). It is two-segmented in Gonophysema gullmarensis (Bresciani \& Lützen, 1961). It is, however, fivesegmented and with one seta on the tip of the terminal segment in Phyllodicola petiti, though the adult is deformed profoundly as in some of the former species (Laubier, 1961). The second antenna of Phyllodicola nauplius bears some peculiar features other than this, viz. the probably three-segmented protopod and with only one seta on the second segment.

The possession of only one terminal seta in the exopod, which is a peculiar ornamentation among the copepod groups except for Caligoida and Lernaeopodoida, is also known for the nauplii of Eurysilenium truncatum and probably Herpyllobius polynoe and $H$. arcticus (Herpyllobiidae) (Lützen, 1968).

\section{2-1-4. The mandible.}

This biramous appendage, like the second antenna functions as the locomotive and feeding organs. It consists of two-segmented protopod, two-segmented endopod and four-segmented exopod throughout the nauplius stages. The fundamental structure and the change of ornamentation with stage for the poecilostome Cyclopoida, except the Ergasilidae, are generalized in Fig. 11. There is no change after the third stage.

The coxa is short, bearing only one spine on the rounded medial margin throughout the naupliar stages. This setation is a clear contrast to the coxa of second antenna which bears two spines after the third stage. This seems to be a feature common not only to the nauplii of the entire Copepoda but also to those of the Maxillopoda and Cephalocarida (see Figs 10, 13, 14). The coxal spine is degenerative or missing in the yolky nauplii of the parasitic forms. It is represented by a spinule in Neanthessius renicolis and Panaietis yamagutii (Izawa, 1986b). It is missing in Pseudomyicola spinosus (Nakamura et al., 1979), Ostrincola koe (Kô et al., 1974), Pseudacanthocanthopsis apogonis and Praecidochondria setoensis (Izawa, 1986b), Sarcotaces pacificus (Izawa, 1973), Colobomatus pupa (Izawa, 1975), and well-simplified nauplii of other various species.

As shown in Fig. 12, the naupliar mandible of the Ergasilidae is distinct from the generalized one in which the coxa and basis unite completely to form a broad one-segmented protopod bearing a single spine on the medial margin, which seems to represent an element of the basis (see Wilson, 1911; Mirzoeva, 1973; Kabata, 1976; Urawa et al., 1980a; Ben Hassine, 1983). 


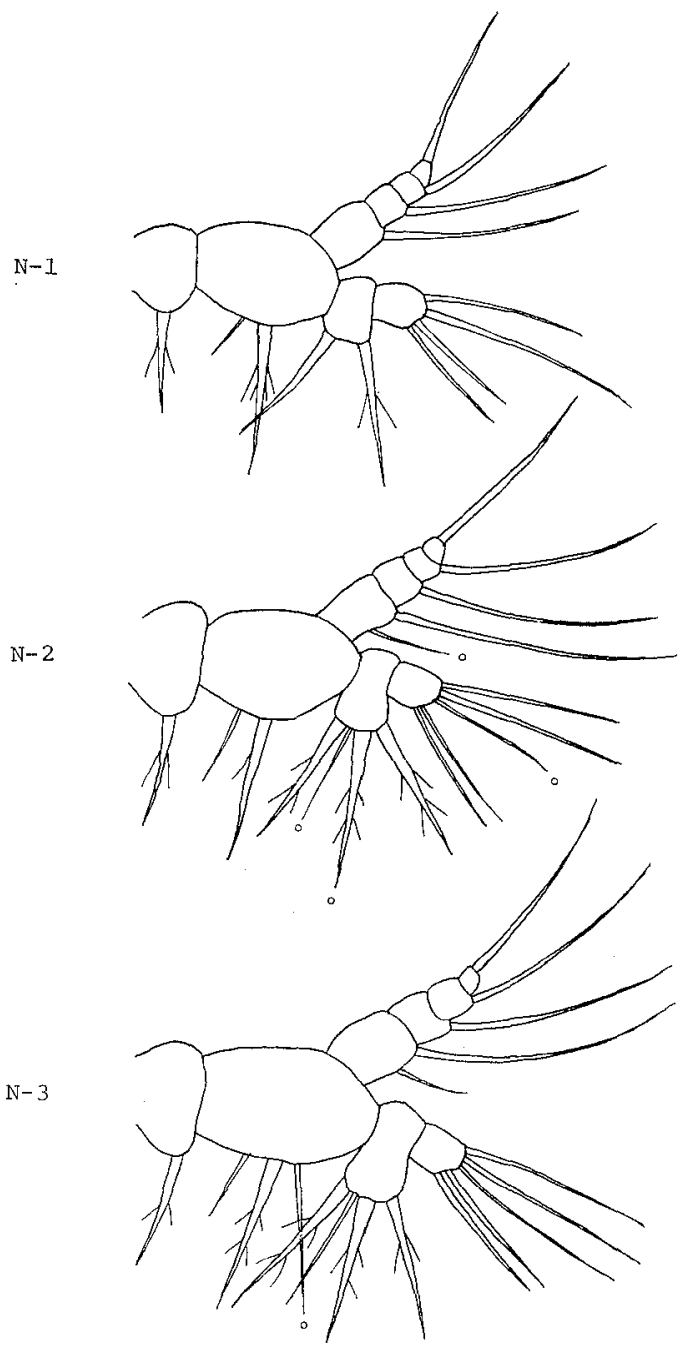

Fig. 11. Generalized morphological changes of the naupliar mandible in the poecilostome Cyclopoida excluding Ergasilidae. Hairs on the setae are omitted. Small circle indicates newly added element. There is no significant change after the third nauplius stage.

On the other hand, in the Calanoida and Harpacticoida, except for Longipedia and Canuella, the coxa forms a masticatory process in the late naupliar stage (see Fig. 14). From the fact mentioned below, this process can be regarded as a heterogeneous structure for the original coxal spine which is common to the entire Copepoda. In a typical calanoid, the medial margin of the coxa protrudes gradually during early naupliar development, and forms a stout process with toothed cutting edge, called "gnathobase", usually in the fourth stage. The original coxal spine is retained at the tip of the medial expansion of the coxa in the early stages, and at the ventral base of the gnathobase in the later stages (see Oberg, 1906; Lebour, 

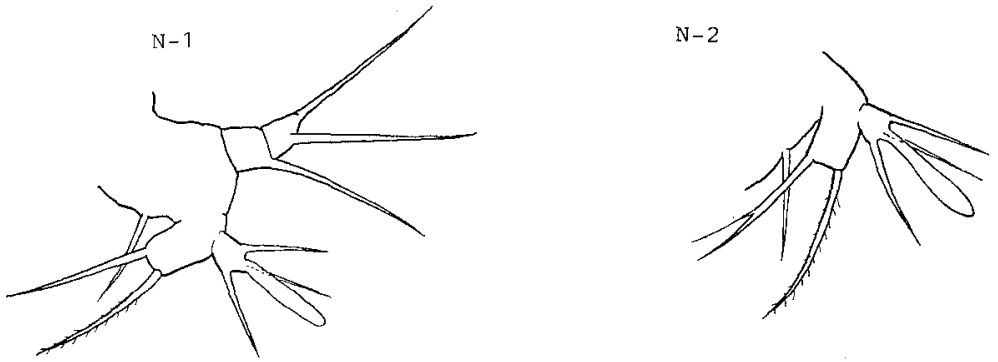

Fig. 12. The mandible of the first nauplius and the endopod of the second nauplius of Neoergasilus japonicus (after Urawa et al., 1980a), with hairs on the exopodal setae omitted. There is no significant change in the remaining naupliar stages, though the proximal spine of the first endopodal segment bears a branch after the second nauplius stage.

A Oithona nana
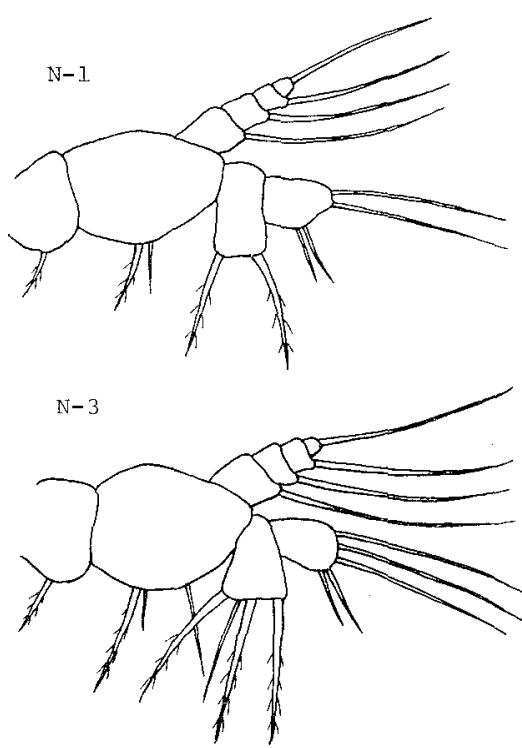

B Cyclops strenuus

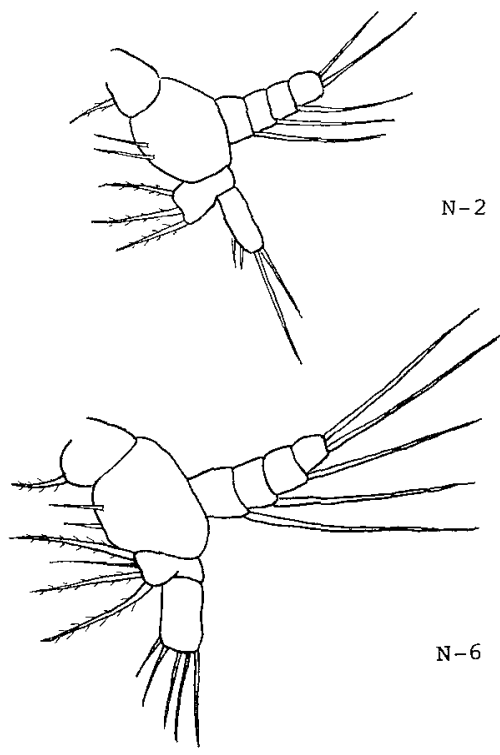

Fig. 13. The naupliar mandibles of the gnathostome Cyclopoida. A, Oithona nana (after Haq, 1965a, as Oithonina nana); B, Cyclops strenus (after Dietrich, 1915).

1916; Gurney, 1934a; Campbell, 1934; Johnson, 1934b, 1935, 1937, 1948, 1966; Steuer, 1935; Humes, 1955; Comita \& Tommerdahl, 1960; Koga, 1960b, 1968; Gaudy, 1961; Ummerkutty, 1964; Matthews, 1964; Shen \& Chang, 1965; Lawson \& Grice, 1970; Uye \& Onbé, 1975; Reddy \& Devi, 1985). On the contrary, lecithotrophic nauplii lack this process, particularly in Euchaeta japonica (Campbell, 1934; Lewis \& Ramnarine, 1969), E. norvegica (Nicholls, 1934), E. marina and Candacia armata (Bernard, 1964), Pareuchaeta russelli (Koga, 1960a), and Tortanus discaudatus and Pontellopsis occidentalis (Johnson, 1934a, 1965).

As shown in Fig. 10, the mandibular coxa with a stout spine-like process accompanied by the original coxal spine at the base is also found in the Cirripedia 


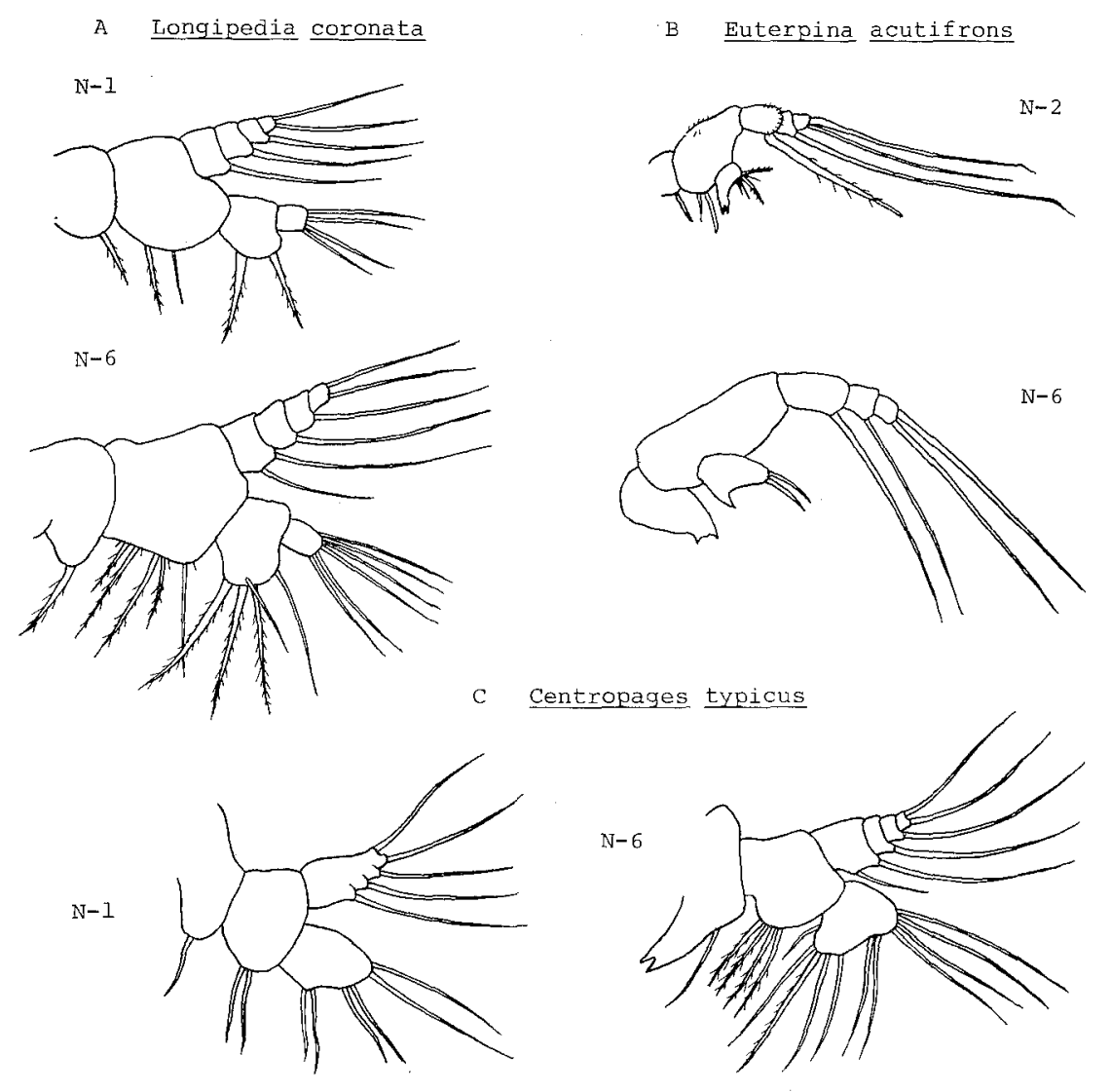

Fig. 14. The naupliar mandibles of the Harpacticoida (A \& B) and Calanoida (C). A, Longipedia coronata (after Nicholls, 1935) ; B, Euterpina acutifrons (after Haq, 1965b); C, Centropages typicus (after Lawson \& Grice, 1970).

(see Bassindale, 1936; Knight-Jones \& Waugh, 1949; Jones \& Crisp, 1954; Barnes \& Barnes, 1959a, b; Dalley, 1984; Egan \& Anderson, 1986; Achituv, 1986) and the Ascothoracida (Yosii, 1931b). In the Mystacocarida and Cephalocarida, the coxa yields a gnathobase with toothed cutting edge, which is also accompanied by the original coxal spine near the base (see Hessler \& Sanders, 1966; Sanders, 1963; Sanders \& Hessler, 1963).

The basis is broad and furnished with two spines on the medial margin in the first stage and an additional spine on the same margin in the third stage. Further change is not found in the succeeding naupliar stages in the poecilostome Cyclopoida (Fig. 11). This is almost the same as that of the free-living gnathostome Cyclopoida (Fig. 13) (Dietrich, 1915; Gibbons \& Ogilvie, 1933; Hanaoka, 1944; Haq, 1965a). As referred to already, in the ergasilid nauplii (Fig. 12), the protopod is onesegmented and has a single seta which is probably representing an element in the basis (Wilson, 1911; Gurney, 1913; Halisch, 1940; Yin, 1957; Zmerzlaya, 1972; Mirzoeva, 1973; Urawa et al., 1980a; except the Wilson's metanauplii and Gurney's 
later nauplii).

Number of the medial spines increases up to four or five by the last nauplius stage in the feeding nauplii of Calanoida (Fig. 14C) (see Oberg, 1906; Lebour, 1916; Gurney, 1934a; Campbell, 1934; Johnson, 1934b, 1935, 1948, 1965, 1966; Steuer, 1935; Humes, 1955; Comita \& Tommerdahl, 1960; Koga, 1960b; Björnberg, 1966, 1972; Lawson \& Grice, 1970; Uye \& Onbé, 1975; Reddy \& Devi, 1985). In most harpacticoids (Fig. 15B), the basis is deformed and has few spine (see Fraser, 1936; Nicholls, 1941 ; Johnson \& Olson, 1948; Krishnaswamy, 1950, 1955; Bresciani, 1960; Ummerkutty, 1960; El-Maghraby, 1964; Haq, 1965b; Vilela, 1969; Carter \& Bradford, 1972; Itô, 1970, 1975; Itô \& Takashio, 1981; Schminke, 1982). On the other hand, the basis is well-developed in Longipedia (Fig. 15A) (see Gurney, 1930b; Nicholls, 1935; Onbé, 1984), Microsetella (Diaz \& Evans, 1983) and Canuella (Vincx \& Heip, 1979), and has five or six medial spines in the last nauplius stage in Longipedia, in contrast with two or three medial spines in the othres as in the Cyclopoida.

Incidentally, a few common features are present in the basis of some of maxillopodan groups and the Cephalocarida (Fig. 10). There is a trend that one of the medial spines develops into a spiniform process in the Cirripedia (see Jones \& Crisp, 1954; Costlow \& Bookhout, 1958; Barnes \& Barnes, 1959a, b; Barker, 1976; Egan \& Heip, 1968), Ascothoracida (Grygier, 1985, an unidentified ascothoracid metanauplius), and Facetotecta (Bresciani, 1965, nauplius y, Hansen). The basis of the Mystacocarida and Cephalocarida are alike in two features: the medial margin protruding into a round swelling and tipped with a tuft of spines at the tip (Delamare-Deboutteville, 1954; Hessler \& Sanders, 1966; Sanders, 1963; Sanders \& Hessler, 1963).

The endopod is two-segmented throughout the naupliar stages in the poecilostome Cyclopoida. As shown in Fig. 11, the first segment in the first naupliar stage protrudes medially and bears two stout, usually hairy, spines at the distal margin of the truncated protrusion. Aside from the ergasilid nauplii, the third stout spine and another weak spine are added on the medial protrusion of the first segment between the two spines in the second nauplius stage. Thus, these three stout spines are arranged in a form of a fork or trident. The second segment in the first naupliar stage is small and furnished with one or two mediodistal spines and two setae on the distal margin. Addition of a seta on the distal margin is usually occurred in the second stage. Thus, ornamental formula of the endopod segments is 4,1 or $2+3$. This is unaltered from the second stage onwards.

As seen from Fig. 13, the structure and setation of the endopod are almost identical in the gnathostome Cyclopoida (see Oberg, 1906; Dietrich, 1915; Ziegelmayer, 1925; Amelina, 1927; Gibbons \& Ogilvie, 1933; Hanaoka, 1944; Johnson, 1953; Rao, 1958; Haq, 1965a; Björnberg, 1972; Koga, 1984). The endopod of Longipedia (Fig. 13A) and Canuella of the Harpacticoida closely resembles the counterpart in the Cyclopoida (see Gurney, 1930b; Nicholls, 1935; Onbe, 1984; Vincx \& Heip, 1979).

On the other hand, the endopod is one-segmented in the Calanoida and most 
harpacticoids (Fig. 14). The endopod of the calanoid nauplii has three tufts of ornamental elements on the medial protrusion, subterminal medial margin, and distal margin. Ornamental formulae of these tufts are 2, 2, 2 in the first stage and 4 or $5,2,4$ in the last stage. In most harpacticoid nauplii, the endopod has a fewer number of ornamental elements. The possible counterpart of the three prominent spines of the first endopodal segment in the cyclopoid nauplii is also found in the endopod of the calanoid nauplii, despite of the difference in segmentation. The tuft of armature on the medial protrusion includes usually three stout spines, which is considered the correspondent of the three prominent spines in question, and the other two tufts correspond to two tufts of the second segment in Cyclopoida (Oberg, 1906; Campbell, 1934; Johnson, 1934a, b, 1935, 1937, 1948, 1965, 1966; Steuer, 1935; Conover, 1956; Humes, 1955; Koga, 1960b; Comita \& Tommerdahl, 1960; Grice, 1969; Lawson \& Grice, 1970; Björenberg, 1972; Uye \& Onbé, 1975; Reddy $\&$ Devi, 1985). Thus, the one-segmented endopod in the Calanoida and perhaps most harpacticoids is considered corresponding with two-segmented condition found in the Gyclopoida, Longipedia and Canuella.

The possible counterpart of these three prominent spines can also be found in the Cirripedia, Ascothoracida, and Mystacocarida. In the Cirripedia (Fig. 10), the endopod is three-segmented, though indistinct in some forms, and has three tufts of elements; the formulae of the segments are usually 4, 3, 4 (see Bassindale, 1936; Knight-Jones \& Waugh, 1949; Jones \& Crisp, 1954; Costlow \& Bookhout, 1958, Barnes \& Barnes, 1959a, b; Barker, 1976; Dalley, 1984; Egan \& Anderson, 1986; Achituv, 1986). The first segment has three spines which are considered to be corresponding with the three prominent spines in the Copepoda. Though most ascothoracid nauplii are degenerative, an ascothoracid metanauplius of unknown taxon is less simplified, and it has the three-segmented mandibular endopod (Grygier, 1985). The endopod has three well-developed spines on both the first and second segments. As the setation of these three segments (ornamental formula 4, 4, 4) matches with that of the Cirripedia, the three spines of the first segment are regarded as the counterparts of the three prominent spines in question. In the metanauplius of Derocheilocaris typicus of the Mystacocarida (Fig. 10), the endopod is threesegmented and has three spines which are considered to be corresponding with the three prominent spines of the Copepoda (see Hessler \& Sanders, 1966). Incidentally, in the Cephalocarida the endopod consists of two lobular segments and has a formula of 4, $2+3$ (see Sanders, 1963; Sanders \& Hessler, 1963).

Among the Copepoda, the three-segmented endopod is found only in the nauplii of a few rather specialized parasitic forms such as Choniosphaera cancrorum (see Connolly, 1929; Johnson, 1957) and Lecithomyzon maenadis (Fischer, 1956) of the Choniostomatidae (siphonostome Cyclopoida), and Eurysilenium truncatum and probably Herpyllobius arcticus and H. polynoes (Lützen, 1968) of the Herpyllobiidae (siphonostome Cyclopoida in Bowman \& Abele, 1982; Schram, 1986; but their systematic position is uncertain).

As shown in Fig. 12, the endopod of the ergasilid nauplii is two-segmented. 
However, it is peculiar not only within the poecilostome Cyclopoida but also among the Copepoda as a whole in the following points: 1) the medial protrusion of the first segment is extremely elongated, forming a cylindrical masticatory process (Kabata, 1976) and attaining about two times as long as the first segment; 2) no additional spine appears on the process, though there are six nauplius stages (Urawa et al., 1980a), and the first segment is provided with only two spines throughout the naupliar stages; and 3) the second segment is tipped with a curious lamina, shaped like "the blade of a cake knife" (Wilson, 1911). Homology and function of this lamina is unknown at the present, though Gurney (1913) called this lamina as "aesthete". These features are shared by all the ergasilid nauplii described thus far except for the problematic metanauplii of Wilson's (1911) Ergasilus centrarchidarum and the later nauplii (fourth nauplius) of Gurney's (1913) Thersitina gasterostei (cf. Wilson, op. cit.; Gurney, op. cit.; Halisch, 1940; Yin, 1957; Zmerzlaya, 1972; Mirzoeva, 1973; Kabata, 1976; Urawa et al., op. cit.; Ben Hassine, 1983). Gurney (op. cit.) mentioned that "the mandible has lost the characteristic flat aesthete of the inner ramus" in the later nauplii (fourth stage) of his T. gasterostei. Wilson (op. cit.), too, mentioned that the lamina was lost in the first metanauplius stage of his $E$. centrarchidarum. On the other hand, Urawa et al. (1980a) have clearly shown that the lamina persists throughout the naupliar stages in Neoergasilus japonicus. The metanauplii of Wilson's (op. cit., pp. 322-326, Figs 34-38) E. centrarchidarum and the later nauplii of Gurney's (op. cit. p. 422, Fig. 5) T. gasterostei coincide to each other in the following points: the mandibular endopod has neither cylindrical masticatory process on the first segment nor a lamina on the second segment, but, instead, has a set of prominent three spines on the first segment. These features are quite the same as the generalized ones for the cyclopoid nauplii. Actually, Wilson's metanauplii and Gurney's later nauplii are quite different not only from all the other ergasilid nauplii studied thus far by other workers but also from the early nauplii of the same species studied by the same workers in all respects. Therefore, I cannot but question Wilson's and Gurney's identification of these larval ergasilids. If this is correct, many discrepancies are resolved.

Regarding the ornamentation of the second endopodal segment, a trend of development is in certain in the poecilostome cyclopoids, except for ergasilids; that is, the spine(s) on the subterminal medial margin develops like those of the three prominent spines in the first endopodal segment but the terminal setae degenerate. This trend is shared by the nauplii of Hemicyclops adhaerens (see Faber, 1966), Bomolochus cuneatus and Holobomolochus spinules (Kabata, 1976), Taeniacanthus lagocephali (Izawa, 1986a), Taeniastrotos pleuronichthydis and Tegobomolochus nasicola (Izawa, 1986b). The trend is also noticeable in Oncaea mediterranea (Hanaoka, 1952b), O. media (Björnberg, 1972; Malt, 1982), though the terminal setae are not necessarily as reduced. In the nauplii of the other species of poecilostome Cyclopoida, the medio-distal spines are setiform and the distal setae never degenerate, such as in Lichomolgus canui (Costanzo, 1969), Paranthessius anemoniae (Briggs, 1977), Doridicola sepiae, Nasomolgus firmus, Philoblenna arabici, Neanthessius renicolis and Panaietis yamagutii (Izawa, 1986b). Therefore, 
this trend is regarded as a characteristic feature of the nauplii of the Taeniacanthiform group, Clausidiidae (including Hemicyclops), and probably Oncaeidae.

In the yolky nauplii, the endopod is reduced. The medial protrusion and the spines on the medial surface of the endopod are reduced in the nauplii of the Myicolidae, Anthessiidae, Sarcotacidae, philichthyidae, Nereicolidae, Chondracanthidae, and Gastrodelphyidae. The endopods of Mytilicola intestinalis (Pesta, 1907; Costanzo, 1959), Trochicola entericus (Bocquet et al., 1963) of the Mytilicolidae cast off all the spines, leaving only two apical setae. It is similar in Eurysilenium truncatum, Herpyllobius arcticus and $H$. polynoe (Lützen, 1968), though segmentation of the endopod (three-segmented) is different from that of the above mentioned species (twosegmented). And so is Gonophysema gullmarensis (Bresciani \& Lützen, 1961a) and Phyllodicola petiti (Laubier, 1961), though they have one-segmented endopod.

The generalized exopod in the poecilostome Cyclopoida, except for the Ergasilidae (Fig. 11), is four-segmented throughout the naupliar stages. Each segment is armed with a seta in the first naupliar stage, and with an additional seta probably representing a segmental component on the first segment in the second stage, such as found in Lichomolgus canui (Costanzo, 1969), Taeniacanthus lagocephali (Izawa, 1986a), and Doridicola sepiae, Philoblenna arabici and Panaietis yamagutii (Izawa, 1986b). The four-segmented exopod is retained even in the nauplii which are well reduced and have fewer number of stages, such as found in the Chondracanthidae (Heegaard, 1947; Izawa, 1986b), Gastrodelphyidae (Dudley, 1964), Nereicolidae (Carton, 1964), and Mytilicolidae (Bocquet et al., 1963). Though it is rare in the poecilostome Cyclopoida, the terminal segment with two or three setae have been reported for the nauplii of Hemicyclops adhaerens (Williams, 1907; Faber, 1966) and species of the Oncaeidae and Corycaeidae (Hanaoka, 1952b; Johnson, 1969; Björnberg, 1972; Koga, 1984; Malt, 1982), aside from the dubious ergasilid nauplii reported by Wilson (1911) and Gurney (1913). However, in the last two families, because of minute size and indistinct segmentation, the exopods are reported with various numbers of segments or different setation even for the identical stage of the same species. The actual number of setae on the terminal segment is unknown in these two families. If these cases are disregarded, the terminal segment of other poecilostome Cyclopoida can be assumed to have one seta.

On the other hand, in the ergasilid nauplii, the exopod is usually three-segmented and maintained as such throughout the development. In Ergasilus, Sinergasilus, and Thersitina, the exopod consists of three segments with each bearing one seta (see Wilson, 1911; Gurney, 1913; Halisch, 1940; Yin, 1957; Zmerzlaya, 1972; Mirzoeva, 1973; Kabata, 1976; Ben Hassine, 1983; excepting the dubious forms reported by Wilson and Gurney). On the contrary, the exopod of Neoergasilus japonicus is unique. It is two-segmented and this segmentation is constant throughout the development (Fig. 12) (Urawa, et al., 1980a). In the exopod of this species, the first segment has one seta and the second segment has two setae, one apical, the other lateral. This setation of the second segment inferrs that the segment was perhaps derived from the fusion of the two distal segments in a three-segmented ramus. 
Although the unique segmentation in $N$. japonicus is easily explained, the exopod of the two ergasilid species described by Wilson (1911b) and Gurney (1913) can not be explained with such simple modification. In the first three nauplii of Ergasilus centrarchidarum (Wilson, op. cit.) and Thersitina gasterostei (Gurney, op. cit.), the exopod consists of three segments and has a seta on each segment in common with the other ergasilids except for $N$. japonicus. However, in the metanauplii of E. centrarchidarum, the exopod consists of five segments and has a setae on each of the proximal four segments and two apical setae on the terminal segment (Wilson, op. cit.). In the fourth nauplius of $T$. gasterostei, it consists of four segments and has a seta on each of the proximal three segments and two apical setae on the terminal segment. There is little doubt that the later nauplii described by them were not ergasilid larvae. All other ergasilid nauplii so far studied are identical to each other in having a single seta on the apex of the terminal segment throughout the naupliar stages.

The generalized structure of the exopod of the poecilostome Cyclopoida is applicable to the exopod of the gnathostome Cyclopoida, Calanoida, and Canuella and Longipedia of the Harpacticoida, except for the armature of two apical setae (Fig. $13,14)$. In the nauplii of most harpacticoids, the number of the mandibular exopodal segment is lesser than that of the generalized one. It varies with species from three to one (see Fraser, 1936; Nicholls, 1941; Lang, 1948b; Johnson \& Olson, 1948; Krishnaswamy, 1950; Bresciani, 1960; Ummerkutty, 1960; El-Mahgraby, 1964; Haq, 1965b; Vilela, 1969; Carter \& Bradford, 1972; Itô, 1970, 1975; Itô \& Takashio, 1981; Schminke, 1982; Diaz \& Evans, 1983; Bourguet, 1986). Cyclopoids of Allantogynus delamarei (Nanaspididae) (Changeux, 1961), Choniosphaera cancrorum (Choniostomatidae) (Connolly, 1929; Johnson, 1957; Cancerilla tubulata (Cancerillidae) (Carton, 1968) and Wilson's (1911) metanauplii of Ergasilus centrarchidarum are known to have five-segmented exopod. All these species, except for the last one, belong to the siphonostome Cyclopoida.

In comparison, the number of segments in the exopod is four or five in the Facetotecta, six in the Cirripedia and Cephalocarida, six or seven in the Ascothoracida, and probably eight in Mystacocarida (for Cirripedia see Bassindale, 1936; KnightJones \& Waugh, 1949; Costlow \& Bookhout, 1958; Barnes \& Barnes, 1959a, b; Dalley, 1984; Egan \& Anderson, 1986; Achituv, 1986: for Ascothoracida see Yosii, 1931a, b; Grygier, 1985: for Facetotecta see Bresciani, 1965; Schram, 1970b; Itô, 1985, 1986: for Mystacocarida sec Delamare Deboutteville, 1954; Hessler \& Sanders, 1966: for Cephalocarida see Sanders, 1963; Sanders \& Hessler, 1963).

As mentioned previously, two types of terminal setation, with one or two setae, are found among the copepod nauplii. In the gnathostome Cyclopoida, both kinds are found. The nauplii of Oithona are considered to have one apical seta on this segment throughout all the stages (Fig. 13A) (Oberg, 1906; Gibbons \& Ogilvie, 1933; Haq, 1965a; Björnberg, 1972; Koga, 1984), though a few problematic illustration are noticed in some works. The nauplii of Cyclops are considered to have two apical setae on this segment throughout all the stages (Fig. 13B) (Dietrich, 1915; Amelina, 1927; Hanaoka, 1944; Johnson, 1953). However, Ziegelmayer 
(1925) described an unique setation for the mandibular exopod of Cyclops, viz. the terminal segment of this ramus consists of four segments with three apical setae throughout all the stages. Since terminal segment furnished with three apical setae is not found in any nauplii studied thus far I suspect the accuracy of this setation. In the Enterocolidae and Ascidicolidae, there is but one apical seta (see Lang, 1948a; Ooishi, 1980). Both types of setation are reported in a single family; $e . g$. in the Notodelphyidae, Notodelphys, Doropygopsis, Pygodelphys and Doropygus have two apical setae, but on the other hand Scolecodes has one such seta (see Dudley, 1966); in the Lernaeidae, it has two apical setae in Lamproglena chinensis (see Sproston et al., 1950), but one such seta in Lernaea (see Wilson, 1918; Gnanamuthu, 1951; Grabda, 1963). Restricting to the species which are considered belonging undoubtedly to the siphonostome Gyclopoida, all the nauplii studied thus far have two apical setae on the terminal segment; e.g., Allantogynus delamarei (Nanaspididae) (Changeux, 1961), Lecithomyzon maenadis (Fisher, 1956), Choniosphaera cancrorum (Connolly, 1929), and Choniomyzon panuliri (Pillai, 1962) of the Choniostomatidae, Ascomyzon paroum and Echinocheres violaceus (Asterocheridae) (Lang, 1949), Cancerilla iubulata (Cancerillidae) (Carton, 1968).

In the Calanoida and Harpacticoida (Fig. 14), the nauplii are considered to have two terminal setae, though three setae in some forms, because of fusion of two distal segments, is also known (see literature cited above). On the other hand, in the nauplii of the Caligoida, the terminal segment is considered to have only one seta (Wilson, 1905; Gurney, 1934b; Sproston, 1942; Heegaard, 1947; Hwa, 1965; Izawa, 1969; Kabata, 1972; Boxshall, 1974; Schram, 1979; Cabbal et al., 1984; etc.). Setation of this segment is uncertain in the Misophrioida. As far as Gurney's (1933) figure is concerned, the nauplius of Misophria pallida, which is the only known nauplius of Misophrioida, has one terminal seta on the right mandibular exopod and two such setae on the left mandible.

Below I shall examine the setation of the terminal exopodal segment in the crustacean nauplii other than the copepods. All cirriped nauplii studied thus far have one seta (see Fig. 10) (Groom, 1894; Bassindale, 1936; Knight-jones \& Waugh, 1949; Jones \& Crisp, 1954; Costlow \& Bookhout, 1958; Barnes \& Barnes, 1959a, b; Barker, 1976; Dalley, 1984; Egan \& Anderson, 1986; Achituv, 1986). This segment has two setae in the Facetotecta (see Fig. 10) (Bresciani, 1965; Schram, 1970, 1972; Itô, 1986), Mystacocarida (Delamare Deboutteville, 1954; Hessler \& Sanders, 1966) and Cephalocarida (Sanders, 1963; Sanders \& Hessler, 1963). In the Ascothoracida, both types of setation are reported: it is one in Dendrogaster (Yosii, 1931 a, as Myriocladus), Baccalaureus (Fig. 10) (Yosii, 1931b) and Laura (Lacaze-Duthiers, 1883), but Grygier (1985) mentioned that in general there might be more than one seta and figured an exopod with two terminal setae for an unidentified ascothoracid metanauplius.

It is interesting to note that most of the above mentioned groups exhibit one type of this setation, though there are a few exceptional cases where two types are found even in a single family. As mentioned above, the gnathostome Cyclopoida 
exhibit both types, the siphonostome Cyclopoida exhibit the two setae type, and the poecilostome Cyclopoida exhibit the one seta type, though a very few exception are known for the latter group. The nauplii of those species, which are currently accommodated in either the Poccilostomatoida or Siphonostomatoida, or treated as being "order uncertain" by Bowman \& Abele (1982) and Schram (1986) are examined below. The exopod which has one terminal seta, regardless of segmentation, is known for the nauplii of the following species: Anteacheres duebenii (see Sars, 1870) (Antheacheridae); Mesoglicola delagei (Taton, 1934) (Mesoglicolidae); Eurysilenium. truncatum, Herpyllobius arcticus, and H. polynoes (Lützen, 1968) (Herpyllobiidae); Gonophysema gullmarensis (Bresciani \& Lützen, 1961) (inceriae sedis), and Phyllodicola petiti of the Phyllodicolidae (Laubier, 1961). On the other hand, the two terminal setae type, regardless of segmentation, is known for the nauplii of the following species: Aphanodomus terebellae of Xenocoelomidae (see Bresciani \& Lützen, 1974) and Spondinticola vermicularis (Spondinticolidae) (Silén, 1963, =Clionophilus vermicularis).

The mandible of Phyllodicola petiti (Laubier, 1961) bears some features which are peculiar not only to the poecilostome Gyclopoida but also to the entire Copepoda, these are: 1) the unarmed and three-segmented protopod, 2) the endopod with only two terminal setae, and 3) the three-segmented exopod. Furthermore, its second antenna and mandible are constructed almost identical to each other, except for the segmentation difference in the exopod. Similar structure is also found in the two biramous appendages in nauplius y of Hansenocaris pacificus and nauplius y, type VII (Itô, 1986).

\section{2-1-5. Labrum.}

In the less reduced nauplii, the labrum is distinct and ornamented with spinules arranged in a row along the distal free margin. Among the nauplii studied by me, this spinular ornamentation is found in Taeniacanthus lagocephali (Izawa, 1986a), Taeniastrotos pleuronichthydis, Tegobomolochus nasicola, Doridicola sepiae, Nasomolgus firms and Philoblenna arabici (Izawa, 1986b), but not in Neanthessius renicolis, Panaietis yamagutii, Pseudacanthocanthopsis apogonis and Praecidochondria setoensis (Izawa, 1986b) as well as Sarcotaces pacificus (Izawa, 1973) and Colobomatus pupa (Izawa, 1975). As illustrated in Fig. 15, two types are discernible in the spinular ornamentation: one is characterized by having discrete groups of spinules of different lengths and the other one is characterized by having subequal and evenly spaced spinules. The former type, which I call taeniacanthiform type, is shared by the nauplii of
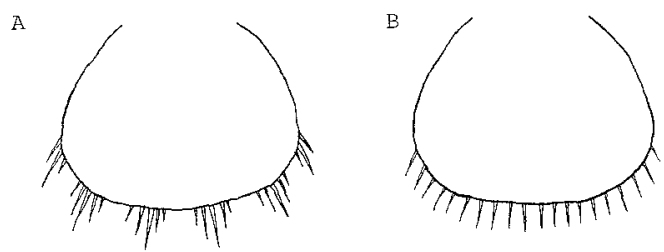

Fig. 15. Two types of ornamentation in the naupliar labrum of the poecilostome Cyclopoida. A, taeniacanthiform type; B, lichomolgiform type. 
Taeniacanthus lagocephali (Izawa, 1986a), Taeniastrotos pleuronichthydis and Tegobomolochus nasicola (Izawa, 1986b), and six other taeniacanthiforms that I have studied but unpublished. The latter type, which I call lichomolgiform type, is shared by the nauplii of Lichomolgus canui (Costanzo, 1969), Paranthessius anemoniae (Briggs, 1977), Doridicola sepiae, Nasomolgus firmus and Philoblenna arabici (Izawa, 1986b), and oncaeids (Björnberg, 1972). The taeniacanthiform type of labrum is found in Oncaea mediterranea (Hanaoka, 1952b) and O. media (Malt, 1982), though Björnberg (1972) illustrated a lichomolgiform type for Oncaea media.

Both types of ornamentation are noticed also in the nauplii of gnathostome Cyclopoida; Oithona has the taeniacanthiform type (see Gibbons \& Ogilvie, 1933; Rao, 1958; Haq, 1965a), while Cyclops has the lichomolgiform type (see Ziegelmayer, 1925; Hanaoka, 1944; Johnson, 1953).

Labrum of the ergasilid nauplii differs from that of the other cyclopoid nauplii. It is elongate, protrudes posteriorly at the middle of the distal margin, and lacks ornamentation, these features are clearly illustrated for Neoergasilus japonicus (Fig. 3) by Urawa et al. (1980a) and for Ergasilus lizae by Ben Hassine (1983).

Most yolky nauplii have a reduced labrum. No ornamentation is found in the Anthessiidae (Izawa, 1986b), Myicolidae (Kô et al., 1974; Nakamura et al., 1979), Gastrodelphyidae (Dudley, 1964), Philichthyidae, Sarcotacidae (Izawa, 1973, 1975), or Chondracanthidae (Heegaard, 1974; Izawa, 1986b). The labrum is indistinct or lacking in the Nereicolidae (Carton, 1964) and Mytilicolidae (Pesta, 1907; Costanzo, 1959; Bocquet et al., 1963).

\section{2-1-6. Labium.}

This structure is inconspicuous even in the well-developed nauplii and almost indefinable in the yolky nauplii. Among the nauplii studied by Izawa (1973, 1975, 1986a, b) the labium was noticed in Taeniacanthus lagocephali, Taeniastrotos pleuronichthydis, Tegobomolochus nasicola, Doridicola sepiae, Nasomolgus firmus, Philoblenna arabici and Panaietis yamagutii. It is represented by a slight elevation of the sternal surface and accompanied usually by a row of fine hairs or spinules on both sides and sometimes also on the posterior margin. Such labial structure in the poecilostome Cyclopoida is almost identical with that in Oithona (see Gibbons \& Ogilvie, 1933; Haq, 1965a), but differs from that in the Calanoida, which is covered with fine spinules (see Oberg, 1906; Gurney, 1934a; Johnson, 1937, 1948; Björnberg, 1966). No labium has been reported for the nauplii of ergasilids and Cyclops. No particular feature characteristic to certain groups of Copepoda is discernible at the present.

2-1-7. Post-mandibular appendages.

Rudiments of the post-mandibular appendages from the first maxilla through first two legs appear in naupliar stages. As they appear in a certain order and the first maxilla usually alters greatly at the fourth naupliar stage, their existence and appearance are useful as a stage indicator.

2-1-7-1. First maxilla.

Formation of the first maxilla in most Cyclopoida can be explained by the 
following scenario (see Fig. 2): it appears first as a post-mandibular seta in the second naupliar stage and it is later replaced by a bilobate structure in the fourth stage. All free-living cyclopoids of which naupliar development is known to exhibit this type of formation. The bilobate first maxilla consists of a short basal portion (protopod) and two setose lobes (rami) (Oberg, 1906; Dietrich, 1915; Amelina, 1927; Gibbons \& Ogilvie, 1933; Hanaoka, 1944; Haq, 1965a; Björnberg, 1972; Goswami, 1975; Briggs, 1977; Koga, 1984). However, slight differences are found in the rudimental first maxilla in the second and third stages of Oithona. Oberg (op. cit.) showed that in Oithona similis the first maxilla appeared as two setae in the second stage and was replaced by a lobe bearing two apical setae in the third stage. Gibbons \& Ogilvie (op. cit.) described that in $O$. helgolandica and $O$. spinirostris the first maxilla appeared as a protuberance bearing a long apical seta in the second stage and a second small seta was added in the third stage. The number of setae on the medial and lateral lobes are 6 and 4 respectively in the Cyclopoida. Identical or similar formation process is found in parasitic cyclopoids. For example Lichomolgidae (Costanzo, 1969) and Anthessiidae (Izawa, 1986b).

Although the formation of the first maxilla in the cyclopoids was given above, formation of this appendage in most parasitic cyclopoids can not be generalized due to some deviations.

One of the deviation in the formation of the first maxilla is represented by Myicolidac, Gastrodelphyidae and Mytilicolidae. Their first maxillae appear as a papilla with an apical seta at certain stage of naupliar development and is unaltered there on. In the Myicolidae, it appears in the fourth stage in Pseudomyicola spinosus, which has six naupliar stages (Nakamura et al., 1979), and in the third stage in Ostrincola koe, which has five naupliar stages (Kô et al., 1974). This is distinctly different from the nauplii of the Anthessiidae, which was recently separated from Myicolidae (Humes, 1986). In Gastrodelphys (Grastrodelphyidae), which has four naupliar stages, it appears in the second stage (Dudley, 1964). In the Mytilicolidae, which has two naupliar stages, it appears in the second stage in Mytilicola intestinalis (Pesta, 1907; Costanzo, 1959), but no sign of the first maxilla appears in Trochicola entericus (Bocquet et al., 1963).

Another deviation is seen in Ergasilidae that has six naupliar stages (Urawa et al., 1980a). The ergasilid nauplii have somewhat reduced first maxilla (Fig. 3), it appears as a small process tipped with a seta in the third or fourth stage (see Gurney, 1913; Yin, 1957; Zmerzlaya, 1972; Mirzoeva, 1973; Urawa et al., op. cit.; Ben Hassine, 1983). However, it is quite different from the same appendage in Ostrincola etc. described above. The first maxilla is two-segmented and has a seta on the first segment and two setae on the second segment in the last nauplius stage of Ergasilus sieboldi (Zmerzlaya, op. cit.). It is also two-segmented, though indistinctly, and has two spinules on the first and a seta on the second segment in the fifth and sixth naupliar stages in Neoergasilus japonicus (Urawa et al., op. cit.). This seems to indicate that the first maxilla of ergasilid nauplii appears in a more developed condition than the same appendage in other cyclopoids. Nevertheless, their first maxillae 
do not change into a bilobate structure.

The first maxilla in Notodelphyidae (gnathostome Cyclopoida), in which five naupliar stages are usually present, is greatly different from that in the other copepods (see Dudley, 1966). It appears as a protuberance bearing a seta and a setule at the tip and protrudes laterally from the body; the posterior margin bears a few minute points. In the third stage, it has a posterior subterminal lobe, on which the minute points are found. The first maxilla shows the formation of a second basal lobe at the fifth stage; the basal lobe represents the endite of the protopod, the central lobe represents the medial margin of the protopod, and the terminal lobe represents the endopod (Dudley, op. cit.). Based on the observation of histological sections, she mentioned that the exopod was formed dorsally to the terminal lobe. However, I prefer to interpret this as follow: the basal lobe, central lobe, and terminal lobe represent the protopod, endopod and exopod respectively, for 1) the lobe representing only a portion of the endite of the protopod is not demarcated from the lobe representing the protopod by a suture and 2) the structure interpreted as the exopod by Dudley in her histological sections, which has a few rudimental setae, is considered corresponding to the outer-distal portion of the protopod, on which the first maxilla of the first copepodite bears a few setae in notodelphyids.

The ornamentation of the rudimentary first maxilla in Lernaea and Lamproglena (Lernaeidae, gnathostome Cyclopoida) differs from that in the other cyclopoids such as myicolids and gasterodelphyids. It appears as a protuberance with two apical setae in the second stage and stays unaltered during the remaining naupliar stages which consist of at least three stages (see Nakai, 1927; Grabda, 1963; Sproston et $a l ., 1950)$. The rudiment is considered corresponding to the terminal lobe of the first maxilla of notodelphyids as the number of apical elements are identical between them. Based on the comparison of the rudimentary first maxillae between the Notodelphyidae and Lernaeidae, I concludes that the exopod or its element(s) appears first as a rudiment of the first maxilla in the Cyclopoida regardless of the succeeding development. The rudimentary first maxilla with two apical elements is found only in the nauplii of Oithona, Notodelphyidae and Lernaeidae among the Gyclopoida. This seems to be a characteristic feature of these gnathostome cyclopoids. In the poecilostome Cyclopoida, the lateral lobe is somewhat larger than the medial lobe and carries a long seta at the tip (Costanzo, 1969; Izawa, 1986b). It is, however, extremely long in the nauplii of the Oncaeidae and Corycaeidae, reaching almost the body length, or more (Johnson, G., 1969; Björnberg, 1972; Malt, 1982; Koga, 1984). This specific feature shared between them can interpreted as an adaptation to pelagic life for floatation such as the long setae on the exopod of the second antennae and the caudal armature.

Complete absence of the first maxilla is known in some parasitic poecilostome cyclopoids. The naupliar stages of Philichthyidae, Sarcotacidae, Chondracanthidae, and Nereicolidae so far reported lack the first maxilla (Carton, 1964; Izawa, 1986b).

In the Harpacticoida, the first maxilla usually appears as a seta or spine in the second nauplius stage and it is replaced by a bilobate structure in the fourth nauplius 
stage. This process of formation is the same as the generalized one in cyclopoids. However, the bilobular structures in the harpacticoids are not prominent when compared with the typical ones in the Cyclopoida (see Fraser, 1936; Lang, 1948b; Johnson \& Olson, 1948; Ummerkutty, 1960; Vilela, 1969; Itô, 1970; Itô \& Takashio, 1981; Carter \& Bradford, 1972; Bourguet, 1986). In the nauplii of Longipedia, Microsetella, Sunaristes, and Canuella, the first maxilla appears in the first nauplius stage as a seta or stout spine on the posterior portion of the body, it is later replaced by a bilobate structure in the fourth stage (see Gurney, 1930; Nicholls, 1935; Lang, 1948b; Hirakawa, 1974; Vincx \& Heip, 1979; Diaz \& Evans, 1983; Onbé, 1984). However, Vincx \& Heip (op. cit.) interpreted this spine in the first nauplii of Canuella and Sunaristes as the furcal seta, and furthermore, they reported that the first maxilla appeared in the second stage. Based on the facts mentioned bellow, I consider a seta or a. stout spine in question, which appears in the first stage in the above mentioned groups, as a rudiment of the first maxilla. This element appears on the the posterior portion of the ventral side, not the caudal end, and slightly moves forward in the succeeding stages as the posterior part of body elongates. The first nauplii of Microsetella has the furcal armature composed of a caudal process and a pair of setae on the caudal end in addition to the pair of setae in question (Hirakawa, 1974). The bilobate first maxilla of Longipedia (Nicholls, op. cit.; Onbé, op. cit.) and Canuella (Vincx \& Heip, op. cit.) resembles closely the generalized one in the Cyclopoida. The first maxilla in Microsetella is similar to the one in Longipedia and Canuella, though it is not so prominent (Hirakawa, 1974; Diaz \& Evans, op. cit.).

In the calanoid nauplii, the first maxilla appears first as a seta in the third nauplius stage and then develops into a prominent bilobate structure which arises from a stout basal portion (protopod) with a lateral seta and setose endites (see Oberg, 1906; Johnson, 1934a, b, 1935, 1948, 1965, 1966; Campbell, 1934; Humes, 1955; Conover, 1956; Comita \& Tommerdahl, 1960; Koga, 1960b, 1984; Gaudy, 1961; Ummerkutty, 1964; Shen \& Chang, 1965; Björnberg, 1966, 1972; Grice, 1969; Lawson \& Grice, 1970).

The first maxilla of the cirriped nauplii first appears as two slight, setose swellings in the second nauplius stage and develops gradually into bilobate appendage during the succeeding stages (see Jones \& Crisp, 1954; Costlow \& Bookhout, 1958; Egan \& Anderson, 1986; Achituv, 1986).

In the Ascothoracida, the first maxilla appears first as a process ending in a spine or pointed tip in an early metanauplius stage such as seen in Baccalaureus japonicus (Yosii; 1931b), and Gorgonolaureus muzikae, Parascothorax ?synagogides and Dendrogaster sagittaria (Grygier, 1985). Later naupliar stages are poorly known for Ascothoracida, and the fate of their rudimentary first maxilla is uncertain. However, in Parascothorax it is known that the rudiment represented by a seta is replaced by a knob with two bumps or spines in a late metanauplius stage. According to Grygier (op. cit.), an unidentified ascothoracid metanauplius collected from a plankton sample had one-segmented first maxilla armed with fine terminal setae.

In the nauplius $y$ of the Facetotecta, no clearly defined rudiment of the first 
maxilla has been reported (Bresciani, 1965; Schram, 1970, 1972; Itô, 1986).

In the Mystacocarida, though the naupliar phase is not well defined, the first maxilla is appears in the first stage as a flattened lobe with five medial teeth and a single distolateral seta in Derocheilocaris typicus (Hessler \& Sanders, 1966). It develops into a substantial appendage which is composed of a stout protopod with setose endites and four-segmented endopod (see Delamare Deboutteville, 1954; Hessler \& Sanders, op. cit.). The uniramous first maxilla of the Mystacocarida is unique in the Maxillopoda.

In the Cephalocarida, the first maxilla appears as a substantial biramous appendage in the first stage. It consists of protopod with medial spines, foursegmented endopod, and foliaceous exopod (see Sanders, 1963; Sanders \& Hessler, 1963).

\section{2-1-7-2. Second maxilla.}

As generalized in Fig. 2, the rudiment of this appendage appears first as a inconspicuous simple fold of the sternal cuticle just behind the first maxilla in the fourth or fifth nauplius stage and then develops into a triangular cuticular sac with a minute pointed tip in the poecilostome Cyclopoida (see Izawa, 1986b). The paired cuticular sacs are clearly separated from each other as in the first maxilla. In more reduced nauplii, no sign of the second maxilla appears such as in Sarcotaces pacificus, Colobomatus pupa, Pseudacanthocanthopsis apogonis, and Praecidochondria setoensis (Izawa, 1973, 1975, 1986b). Although ergasilid nauplii are not particularly reduced, they have no rudiment of the second maxilla. An example of Neoergasilus is shown in Fig. 3. The nauplii of the gnathostome Cyclopoida have similar cuticular sacs representing the second maxillae as seen in Oithona, Cyclops, and notodelphyids (see Oberg, 1906; Dietrich, 1915; Ziegelmayer, 1925; Hanaoka, 1944; Johnson, 1953; Dudley, 1966).

In Harpacticoida, this is almost the same in the nauplii of Longipedia, Canuella, Euterpina, and Tisbe (see Gurney, 1930; Johnson \& Olson, 1948; El-Maghraby, 1964; Haq, 1965b; Vilela, 1969; Itô, 1970; Vincx \& Heip, 1979; Onbé, 1984). Their second maxillae are more prominent than the generalized one for the Cyclopoida, it is represented by a cuticular sac with a long seta or indentation on the distal margin in the nauplii of Microsetella, Canthocamptus, Phyllognathopus, Bryocamptus, (Lang, 1948 b; Carter \& Bradford, 1972; Björenberg, 9172; Hirakawa, 1974; Itô \& Takashio, 1981 ; Diaz \& Evans, 1983). The rudiment of the second maxilla of Canuella perplex and Longipedia americana, reported by Vincx \& Heip (op. cit.) and Onbé (op. cit.), is a pair of bilobate structures with a seta or short spine. They believe that each of the bilobate structures represents a rudiment of the second maxilla. My explanation is different. In a bilobate structure, the medial lobe represents a rudiment of the maxilliped and the lateral lobe represents the second maxilla in both cases. The reason for this interpretation will be given later.

In the calanoid nauplii, a paired buds of the second maxillac appear also in the fourth or fifth stage. These buds are sac-like swellings and widely separated from each other. Each bud develops further during later naupliar stages into a prominent 
structure which is composed of a broad basal part with setose endites and a distal part representing the endopod (see Oberg, 1906; Gurney, 1934a, Campbell, 1934, Johnson, 1934a, b, 1935, 1937, 1948, 1965, 1966; Humes, 1955; Conover, 1956; Comita \& Tommerdahl, 1960, Gaudy, 1961; Matthews, 1964; Shen \& Chang, 1965, Lauson \& Grice, 1970; Björnberg, 1972; Koga, 1984). Later calanoid nauplii have a pair of juxtaposed cuticular sacs just behind the second maxillae and anterior to the paired first legs. These cuticular sacs are not a part of the second maxillae but rudiments of the maxillipeds. This fact will explain a curious structure found in the certain harpacticoids. As mentioned earlier, nauplii of Canuella and Longipedia have paired bilobate structures located behind the first maxillae. The medial lobes, which are juxtaposed, are actually rudiments of maxillipeds, and the lateral lobes are rudiments of the second maxillae.

No external rudiment of the second maxilla has been reported for the nauplii of the Cirripedia and Facetotecta. For the Ascothoracida, information about the differentiation of the second maxilla is very poor. In Parascothorax, the second maxillae first appear in a late metanauplius stage as a pair of knobs bearing two bumps or spines (Grygier, 1985). The second maxilla of the Mystacocarida is fundamentally the same as the Copepoda especially in its uniramous feature (see Delamare Deboutteville, 1954; Hessler \& Sanders, 1966). On the contrary, the second maxilla in the Cephalocarida is more distinctive than those in the maxillopodans, because it has two rami and a pseudepipodite (=epipodite) (see Sanders, 1963; Sanders \& Hessler, 1963; Schram, 1986).

2-1-7-3. Maxilliped.

In the Cyclopoida, a pair of maxillipeds appear as a juxtaposed cuticular sacs slightly behind the second maxilla in the last naupliar stage. They often look as if they were placed between the second maxillae, which are widely spaced (Fig. 2). This is clearly seen in Oithona (Oberg, 1906), Cyclops (Dietrich, 1915), Hemicyclops (Faber, 1966), Lichomolgus (Costanzo, 1969), and Neanthessius and Panaietis (Izawa, 1986b). The maxilliped never appears in the most yolky nauplii such as the Myicolidae (Kô et al., 1974; Nakamura et al., 1979), Mytilicolidae (Pesta, 1907; Costanzo, 1959; Bocquet et al., 1963), Gastrodelphyidae (Dudley, 1964), Sarcotacidae, Philichthyidae, and Chondracanthidae (Izawa, 1973, 1975, 1986b). The ergasilid nauplii have no rudiment of the maxilliped either (Fig. 3) (Urawa et al., 1980a).

Similar juxtaposed rudiments of the maxillipeds have been reported for the nauplii of Longipedia and Canuella (Vincx \& Heip, 1979; Onbé, 1984). The juxtaposed broad cuticular folds, which I consider as the maxillipedal rudiments, are illustrated in the sixth nauplius of Tigriopus japonicus by Ito (1970). Although he interpreted a pair of lamellae, which are located behind the cuticular folds in question, as the rudiments of the maxillipeds, I prefer to call them the rudiments of the first legs. My reasoning is as follows. Each of these lamellae has indentation on the narrowed distal margin, which resembles cuticular sac of leg, and is followed by a similar lamella, though it has two terminal spines instead of indentation, whcih he called the rudiments of the first legs. The last nauplius stage of Canthocamptus has a pair of 
maxillipedal rudiments, which are papillary (see Lang, 1948b; Itô \& Takashio, 1981). The paired rudiments are not juxtaposed but very widely spaced, unlike those in Longipedia and Canuella.

In the Calanoida, the maxilliped appears as a minute swelling of the sternal surface in the fifth nauplius stage and develops usually into an elongate uniramous appendage in the last naupliar stage (see Oberg, 1906; Gurney, 1934a; Campbell, 1934; Steuer, 1935; Johnson, 1937, 1966; Humes, 1955; Comita \& Tommerdahl, 1960; Koga, 1960a, b; Ummerkutty, 1964; Björnberg, 1972; Lawson \& Grice, 1970; Reddy \& Devi, 1985). The maxilliped in the last naupliar stage is two-segmented, though indistinct in some cases, and tipped with some setae.

The nauplii of the Cirripedia and Facetotecta have no structure corresponding to the maxilliped of the Copepoda.

\section{2-1-7-4. First and second legs.}

In the Cyclopoida, rudiments of the two pairs of legs appear as large cuticular sacs in the sixth naupliar stage (generalized contour of the cuticular sacs of the poecilostome Cyclopoida except for ergasilids is illustrated in Fig. 2). The cuticular sac of each leg is composed of medial and lateral lobes which are indented apically and represent rami. This is essentially the same throughout all copepod groups.

The structure of the first two legs of ergasilid nauplii are peculiar. In ergasilid nauplii, rudiments of the first two legs are bilobate as in other cyclopoids, and their medial lobes are as usual. However, each of their lateral lobes narrows distally to form an acute spine, and paired lobes cross with each other medially (Fig. 3). In contrast to ergasilid's legs, the lateral lobe in the other cyclopoids such as Hemicyclops, Lichomolgus, Ostrincola, Pseudomyicola, Neanthessius, and Panaietis (sce Faber, 1966; Costanzo, 1969; Kô et al., 1974; Nakamura et al., 1979; Izawa, 1986b) is indented apically as shown in Fig. 2. The cuticular sacs for the two legs appear even in those nauplii which have no post-mandibular oral appendages; viz. Neoergasilus, Ostrincola, Pseudomyicola, and besides Gastrodelphys (Dudley, 1964), Colobomatus, Sarcotaces, and chondracanthids (Izawa, 9173, 1975, 1986b). However, there are a few instances that cuticular sacs of two legs do not appear in any naupliar stages. Nauplii of Selioides bocqueti (Carton, 1964) and Mytilicola intestinalis (Pesta, 1907; Costanzo, 1959) are the case in point.

Calanoid nauplii have the cuticular sacs for the first two legs, which are fairly large and generally with spines. In some cases the rudimentary third legs are also noticcable (see Oberg, 1906; Gurney, 1934a; Campbell, 1934; Steuer, 1935; Johnson, 1934-1966; Conover, 1956; Grice, 1969; Lawson \& Grice, 1970; Björnberg, 1972; Reddy \& Devi, 1985). Although two pairs of maxillae are widely spaced as mentioned above, the paired legs are juxtaposed as in the maxilliped. This seems to be the fundamental difference between the cephalic and the thoracic appendages. However, the paired legs as well as the paired maxillipeds are widely spaced in the nauplii of the Harpacticoida except for Longipedia and Canuella (Fraser, 1936; Lang, 1948b; Johnson \& Olson, 1948; Ummerkutty, 1960; El-Maghraby, 1964; Haq, 1965b; Vilela, 1969; Itô, 1970; Carter \& Bradford, 1972; Hirakawa, 1974; Itô \& Takashio, 1981; Diaz \& Evans, 1983; Bourguet, 1986). 


\section{Chapter II. Phylogenetic Implications of the Naupliar Features}

\section{Abbreviation of naupliar stage}

\section{1-1. Abbreviated development.}

It is safe to say that the Copepoda has fundamentally six naupliar stages (see $I, 2)$. However, as already shown in the previous chapter a trend to reduce naupliar stages (abbreviated naupliar development) is known in many species which yield lecithotrophic nauplii. Then, it is logical to ask which stages are skipped, and in what sequence does it occur? What does the degree of abbreviation mean? In this section, I will try to answer these questions which undoubtedly carry cues for the analysis of copepod phylogeny.

As already shown in previous chapter ( $I, 2-1)$, six naupliar stages are essentially definable based upon the setation of appendages, furcal armature and structure of the post-mandibular appendages. What concerns us is the matter of how these features appear or are retained in the naupliar stages when the naupliar stage is abbreviated. Needless to say, the stages of nauplii, as in other crustaceans, are defined by moults and identified by possession of certain external characteristics, not by possession of them inside their cuticle. It is often found that in a species with abbreviated development its nauplius exhibits composite characteristics of various stages. In this case, this nauplius may be assigned to any of these fundamental stages. However, since the progression of development is a sequential process, the appearance of characters representing the most advanced stage may better serve as the indicators of the nauplius in question. On this basis, the naupliar stages of the abbreviated development are determined and assigned.

The first naupliar stage is always stable and well defined in the sense that the characters of later stage never appear. Even in those species with abbreviated development, features of the later stages never appear in their first nauplii, such as in Ostrincola, Neanthessius, Panaietis, colobomatus, Sarcotaces, Gastrodelphys, Sabellacheres, notodelphyids, chondracanthids, Allantoginus, Lernaea, Selioides, Mytilicola, Trochicola, and Gonophysema (see Pesta, 1907; Heegaard, 1947; Bresciani \& Lützen, 1951; Changeux, 1961; Costanzo, 1963; Bocquet et al., 1963; Grabda, 1963; Carton, 1964; Dudley, 1964, 1966; Kô et al., 1974; Izawa, 1973, 1975, 1986b).

The last three of the five naupliar stages in Neanthessius renicolis and Panaietis yamagutii (Izawa, 1986b) correspond to the original fourth, fifth and sixth stages, since they are provided with bilobate first maxillae (see I, 2-1-7-1) and their last nauplius has cuticular sacs of two legs (see I, 2-1-7-4). The last three of the five naupliar stages in Ostrincola koe (Kô et al., 1974), Colobomatus pupa (Izawa, 1975) and Sarcotaces pacificus (Izawa, 1973) are also attributable to the original fourth to sixth stages. It is apparent from their furcal armature (see I, 2-1-1), setation of the terminal segment of the first antenna (I, 2-1-2), and the possession of two legs in the last stage (I, 2-1-7-4), though the development of their first and second maxillae 
is deviated from the supposed original condition. In the former species the first maxilla is represented by a seta even in the last naupliar stage and the second maxilla does not appear at all. In the latter species neither first maxillae nor second maxillae appear. The second of the five stages in Ostrincola and Neanthessius correspond to the original third naupliar stage; this is evidenced through the possession of additional elements in the furcal armature (see I, 2-1-1) as well as the terminal armature of the second antenna exopod (see I, 2-1-3). Thus, in these species with five naupliar stages, it is the original second stage that is omitted from their naupliar development.

The last nauplii of the four naupliar stages in the Sabellacheres gracilis and S. illgi of the Gastrodelphyidae (Dudley, 1964) can be assigned to the original sixth stage, for they have cuticular sacs of the two legs (see I, 2-1-7-4). Their second and third stages are attributable to the original fourth and fifth stages, judging from the ornamentation of furcal armature (see I, 2-1-1) and the terminal segment of the first antenna (see $I, 2-1-2$ ) in the second stage and from the development of ornamental elements of the first antenna in the third stage. Thus, the second and third original stages are omitted in these species with four naupliar stages.

Due to the possession of cuticular sacs of the two legs, the last nauplii of the following species with three naupliar stages are also considered corresponding to the original sixth stage: Pseudacanthocanthopsis apogonis and Praecidochondria setoensis of the Chondracanthidae (Izawa, 1986b), and Allantoginus delamarei of the Nanaspididae (siphonostome Gyclopoida) (Changeux, 1961). The sccond nauplii of Pseudacanthocanthopsis can be regarded to as representing the original fifth stage because the first antenna has five short spines on the terminal segment (see I, 2-1-2). The second nauplius of Allantoginus can also be considered as representing the original fifth stage, for it has cuticular sacs of probably the second maxillae and maxillipeds (see I, 21-7). The last nauplius of Lernaea cyprinacea (Lernaeidae, gnathostome Cyclopoida) (Grabda, 1963) seems to represent the original sixth stage, because its first antenna is furnished with a full complement of subapical spines (see I, 2-1-2). Thus, while the original second and third stages are omitted in those species with four naupliar stages, the original second to fourth stages were omitted in those species with three naupliar stages.

Two naupliar stages are present in Gastrodelphys fernaldi of the Gastrodelphyidae (Dudley, 1964), Selioides bocqueti of the Nereicolidae (Carton, 1964), and two species of the Mytilicolidae, Mytilicola intestinalis (Pesta, 1907; Caspers, 1939; Costanzo, 1959) and Trochicola entericus (Bocquet et al., 1963). The last nauplius of Gastrodelphys represent the original sixth stage, for it has the cuticular sacs of the two legs. The last nauplius of Mytilicola is also attributable to the original sixth stage as it exhibits some features of this stage: a claw-like spine on the endopod of the second antenna (see I, 2-1-3) and five pairs of additional short spines on the furcal armature (see I, 2-1-1) (Pesta, op. cit.; Costanzo, op. cit.). The second antenna of Trochicola, too, has the claw-like spines on the corresponding location (Bocquet et al., op. cit.). Thus, it seems that the original second to fifth stages are omitted in these species with two 
naupliar stages. Contrary to these genera, the last nauplius of Serioides is different in lacking characteristic feature of the original sixth stage.

In conclusion, the trend is obvious that the omission of naupliar stage in the abbreviated development occurs in the stage that follows the first naupliar stage, or, in other words, the original second stage and then proceeds to the omission of the new second stage.

\section{1-2. Significance of abbreviation in the naupliar development.}

In a naupliar development that consists of six feeding stages, two kinds of morphological changes are distinguishable. The first kind involves little changes to complete the second antennae and mandibles as feeding apparatus. This process usually occurs in the original second and third stages (see I, 2-1-3, 2-1-4). As demonstrated by Izawa (1986a, b), any nauplii can grow into the second stage without feeding but feeding nauplii can not grow into the third stage without food (see $I, 2$ ). The second kind involves serial changes directed toward the formation of the first copepodid. This process is achieved chiefly through the last three naupliar stages, including elongation of the posterior portion of the body, formation of the post-mandibular appendages (see I, 2-1-7), and addition of spines on the first antennae (see I, 2-1--2) and furcal armature (I, 2-1-1). In most species with six feeding naupliar stages, addition of new external structure takes place at every molt. All these six stages are indispensable for them to complete the naupliar development and to grow into the copepodid. If there appears a stage in which no new structure is added, then the stage would be no longer necessary, and the relevant moulting would be abandoned. For the nauplii exempted from feeding by accumulation of sufficient amount of yolk, the possession of feeding apparatus is not indispensable and the stages that are not accompanied with morphological changes could become dispensable and eventually be omitted. Actually, the feeding apparatus on the second antenna and mandible are degenerative in the lecithotrophic nauplii in all the stages, and the additional elements which should appear in the original second and third stages do not appear (see I, 2-1-3, 2-1-4).

Major external changes in the naupliar stage for preparation of the first copepodid structure are as follows: 1) enlargement of the body cuticle with growth, especially elongation of the hind body (see I, 2), 2) addition of ornamental elements on the first antenna (I, 2-1-2) and furcal armature (I, 2-1-1), 3) formation of claw (s) on the endopod of second antenna (in the species which has claw(s) on the endopod of second antenna in the copepodid stage) $(\mathrm{I}, 2-1-3)$, and 4) formation of cuticular outgrowths, in which the buds of the postmandibular appendages of the first copepodid stage are formed $(\mathrm{I}, 2-1-7)$. As mentioned previously and shown in Table $3(I, 2)$, the first nauplii which are produced from large yolky eggs are large, and very little growth in size is achieved throughout their naupliar stages. For these nauplii enlargement of the body cuticle seems to be unnecessary for reaching the copepodid stage. Presumably, the consumption of yolk during the development of these nauplii would make space available, for the formation of new structures and so 
moulting as a mean to enlarge such space for the new structures would not be essential for them. The cuticular outgrowths in each naupliar stage may also become dispensable and reduced. This is supported by the fact that, in many species, such simplified nauplii without all or some of cuticular outgrowths can yield the usual first copepodids (see Pesta, 1907; Caspres, 1939; Costanzo, 1959; Bresciani \& Lützen, 1961 ; Bocquet, et al., 1963; Dudley, 1966; Kô et al., 1969c, 1974; Izawa, 1973, 1975, 1986b).

Although naupliar stages can be omitted, the first stage is always present and characters of the later stage never appear in this stage. There is no case in which the original second naupliar stage is retained in an abbreviated development. The original second and subsequent stages can be omitted, they are passed entirely internally in the first stage or partly involved in the new second stage (Fig. 16). In this regard, the first stage nauplius is of particular nature, but why should it be produced is not known.

As mentioned previously, it is conceivable that the formation of yolky eggs has occurred independent of the lineage (see I, 1). Once the amount of yolk attains the level enough for the lecithotrophic life (roughly with an egg diameter of $120 \mu \mathrm{m}$ in the poecilostome Cyclopoida, see I, 1), serial process of reduction of external structure (I, 2-1) and abbreviation of the naupliar stage (II, 1-1) may occur. Thus, similar phenomena of reduction in the naupliar morphology and decreasing the number of naupliar stages can proceed independently in separate lineages.

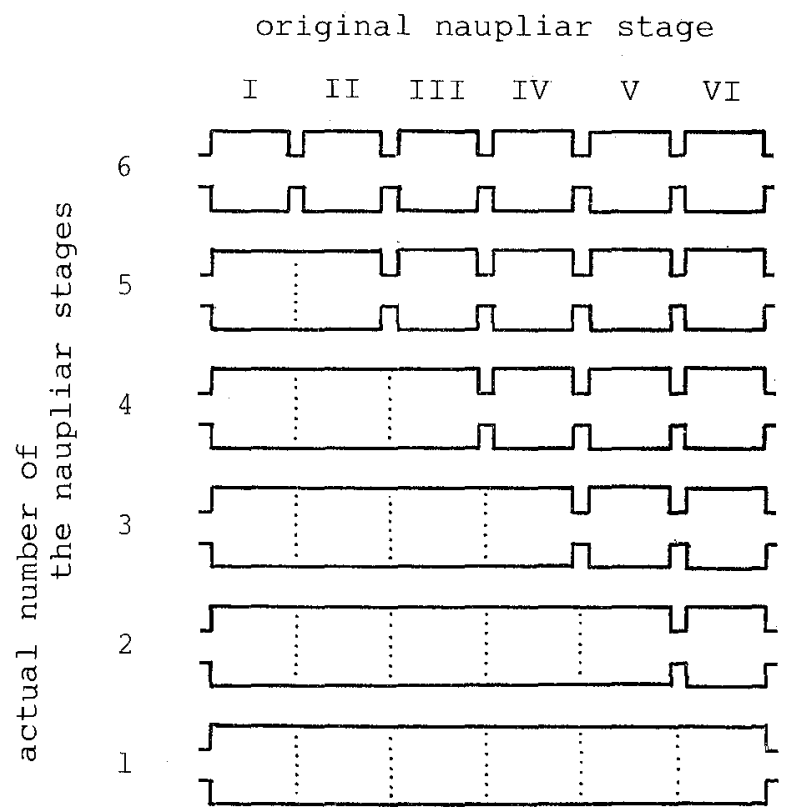

Fig. 16. Schematic representation of progressive abbreviation of the naupliar stage. Indentations indicates moulting that defines stages. Omitted stages are, in many cases, not entirely passed in the first stage, and some of the stage characters are produced in the subsequent stage, hence, the succeding stage is a composite stage. 
However, when such phenomena are examined for a lineage, these information may offer important insight on the history of the respective lineage. If this examination is applied to parasitic copepods, it would indicate the time lapse since their ancestors began a total parasitic mode of life.

\section{Naupliar features}

\section{2-1. Copepod nauplii.}

Copepod nauplii are distinguishable from those of Cirripedia by lacking a pair of frontal filaments, the paired lateral horns, a prominent caudal spine and abdominal process; from those of Ascothoracida by the absence of a pair of frontal filaments and a caudal process; from those of Facetotecta by wanting a peculiar cephalic shield with mesh-like sculptures and a caudal horn; and from those of Mystacocarida and Cephalocarida by lacking a segmented body. Maxillopodans have metabolous development, but the Mystacocarida is unique within the Maxillopoda for having the ametabolous development as in the cephalocaridans.

Although the copepod nauplii are so distinguishable from those of the other Maxillopoda and Cephalocarida, they have some fundamental characteristics in common. Especially the structure of the three principal appendages: viz. homology in the ornamentation of the first antenna, despite of the difference in segmentation (see I, 2-1-2), and in the structure and ornamentation of the second antennae $(I, 2-1-3)$ and the mandible $(I, 2-1-4)$. In addition, nauplii of certain copepods have a caudal process, which is deemed homologous to the one found in the nauplii of the Cirripedia, Ascothoracida, Facetotecta and Mystacocarida (see I, $2-1-1$ ).

It is noteworthy that some similarities are found even in the fossil arthropod larvae (Fig. 17). The larvae reported by Müller \& Walossek (1986a, b) from the Upper Cambrian of Sweden are characteristic in having three groups of armature on the ventral face of the first antenna, five groups of armature in all on the ventral face of both the second antenna and mandible which correspond to the elements of the coxa, basis and three segments of endopod in the Maxillopoda and Cephalocarida;

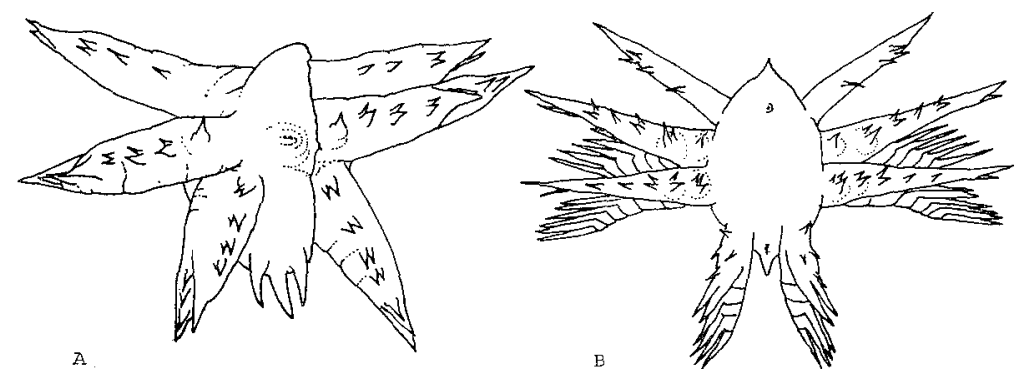

Fig. 17. Fossil arthropod larvae. A, larva A from the Upper Cambrian of Sweden, body length $100-130 \mu \mathrm{m} ; \mathrm{B}$, metanauplius-like larva of Martinssonia elongata from the Upper Cambrian of Sweden, body length $190 \mu \mathrm{m}$, (after Müller \& Walossek, 1986b). 
furthermore, they have a caudal process as seen in the Maxillopoda. These fossils are interpreted by Müller and Walossek ( $o p$. cit.) as larvae of "pre-crustacean" euarthropods. If they are correct, such structures shared among the maxillopodans may be regarded as plesiomorphic features first appeared in their "pre-crustancean" ancestors. The paired "ventro-caudal spines" of the "larva A", though interpreted by Müller \& Walossek (1986b) as incipient furcal armatures (see Fig. 17A), could represent the rudiment of the fourth appendages which correspond to the first maxillae in the Maxillopoda. This pair of spines seems to have been replaced by the fourth biramous appendages in the "metanauplius-like larva" of Martinssonia elongata (see Fig. 17b). In my opinion the "larva $A$ " could be a stage preceding this "metanauplius-like larva".

The Mystacocarida is unique in the Maxillopoda in having an uniramous naupliar first maxilla. With respect to the structure of the post-mandibular appendages of the crustacean nauplii, there are significant differences between the Maxillopoda and Cephalocarida. Cephalocarida is distinct from the maxillopodans in bearing a foliaceous exopod in the first maxilla $(I, 2-1-7-1)$. The second maxilla of the Cephalocarida is also different from that of the maxillopodans in having two rami and a pseudepipodite (=epipodite) (I, 2-1-7-2).

\section{2-2. Major copepod groups.}

In this section, characteristic features of the three major groups of Copepoda, i.e. Calanoids, Harpacticoida and Cyclopoida, are discussed. The nauplii of these groups are usually distinct from each other in the body shape (see I, 2-1) as well as in the structures of the appendages in the later stages of development. The calanoid nauplii are characterized in the following features in the appendages: 1) the first antenna is comparatively large and has broad or elongate distal segment (I, 2-1-2), 2) the second antenna has many additional setae on the second exopodal segment in the later stages (I, 2-1-3), 3) the mandible has one-segmented endopod with a prominent medial protrusion $(\mathbf{I}, 2-1-4)$, 4) labrum is large and spinulose $(\mathbf{I}, 2-1-5)$, 5 ) the first maxilla appears first at the third nauplius stage and then develops into a prominent bilobate structure with setose endites (I, 1-1-7-1),6) the second maxilla, too, develops into a prominent structure with setose endites $(I, 2-1-7-2), 7)$ the maxilliped develops usually into an elongate uniramous appendage (I, 2-1-7-3), and 8) the furcal armature is asymmetrical (I, 2-1-1).

The nauplii of the Harpacticoida and Cyclopoida, in comparison with those of the Calanoida, are rather alike, despite of clear difference in the body shape (I, 2-1). The nauplii of Canuella and Longipedia bear many features in common with the cyclopoid nauplii, yet they are distinct from the latter with the appearance of the first maxilla, as early as in the first stage, a prominent spine or process (I, 2-1-7-1), and furthermore, nauplii of Longipedia usually have a prominent caudal process (I, 2-11). Most harpacticoid nauplii have the following distinct characteristics: 1) the coxa of second antenna has gnathobase $(I, 2-1-3), 2)$ the endopod of second antenna is generally deformed into a long, process-like segment (I, 2-1-3), and 3) the 
cuticular sacs for the maxillipeds and two legs are not juxtaposed but very widely spaced ( $I, 2-1-7-3 \&-4)$. On the other hand, most harpacticoid nauplii resemble the typical calanoid nauplii in having gnathobase on the mandible $(I, 2-1-4)$. No mandibular gnathobase is formed in the nauplii of either Canuella or Longipedia; Cyclopoida has no gnathobase on their naupliar mandible, either.

Three major types of mouth-parts have been recognized in the cyclopoid copepods, namely gnathostome, poecilostome and siphonostome. These structural differences have been used as important key character to discriminate higher taxa within the Cyclopoida (Sars, 1918; Kabata, 1979). However, no such discriminative characteristics are detected in the feeding apparatus of their naupliar stages.

\section{Systematic and phylogenetic consideration}

3-1. Systematic position of some cyclopoid groups.

As mentioned in the previous chapter ( $\mathrm{I}, 2-1-4)$, two types are discernible in the mandibular setation among copepod nauplii as well as among the nauplii of the other maxillopodans. The mandibular exopod is tipped with two setae, regardless of segmentation, in the Calanoida and Harpacticoida, and one setae in the Caligoida and Lernaeopodoida. In the gnathostome Cyclopoida, both types are found: it is two setae in Cyclops, but one seta in the Oithona, Enterocolidae and Lernaeidae. In regard to the species whose systematic position are certain, it appears that the nauplii of the siphonostome cyclopoids exhibit the two setae type, while those of the poecilostome cyclopoids exhibit the one seta type $(\mathbf{I}, 2-1-4)$. Thus, the mandibular setation seems to conform with the cyclopoid grouping to certain extent.

This feature would be useful for finding the systematic position of uncertain cyclopoids whose adults show profound deformation and degeneration. Thus, the Antheacheridae, Mesoglicolidae, Herpyllobiidae, and Gonophysema incertae sedis are, accordingly, attributable to the poecilostome Cyclopoida since their nauplii exhibit the one-seta-type (I, 2-1-4), though the first two families have been treated as "order uncertain" and the third family has been accommodated in the Siphonostomatoida by Bowman \& Abele (1982) and Schram (1986). On the other hand, the Spondinticolidae, which has been treated as "order uncertain" by the same authors (op. cit.), is, accordingly, attributable to the siphonostome Cyclopoida, because their nauplii exhibit the two-setae-type (I, 2-1-4). The Xenocoelomidae has been correctly accommodated in the Siphonostomatoida by the same authors (op. cit.), for their nauplii exhibit the two setae type (I, 2-1-4).

3-2. Systematic position of the Phyllodicolidae.

The nauplius of Phyllodicola petiti (Laubier, 1961), which is accommodated in the Poecilostomatoida by Bowman \& Abele (1982) and Schram (1986), has one seta at the tip of other mandibular exopod (I, 2-1-4) as the nauplii of the poecilostome Cyclopoida. However, this nauplius bears some features which are peculiar not 
only for the poecilostome Cyclopoida but also for the whole Cyclopoida, they are: 1) the unusual segmentation of the first antenna (I, 2-1-2), 2) the unusual segmentation of the second antennal protopod with only one seta on the second segment (I, 2-1-3), and 3) the three-segmented mandibular protopod without armature (I, 2-1-4). It is, thus, very unlikely that Phyllodicola is a member of the Cyclopoida.

\section{3-3. Systematic position of the Ergasilidae.}

Comparison of naupliar features from various groups in the preceding chapter revealed unexpectedly that the later nauplii of Ergasilus centrarchidarum and Thersitina gasterostei reported, respectively, by Wilson (1911, Figs 34-38) and Gurney (1913, Fig. 5) are in reality not ergasilid but probably Cyclops.

The nauplii of the Ergasilidae are unique in many aspects not only in the Cyclopoida but also in the whole Copepoda. Their unique features are: 1) the unusual ornamentation of the first antenna with spines aggregated on the dorso-distal margin of the terminal segment and without aesthete (see I, 2-1-2); 2) the second antenna with only a single, unusually developed coxal spine and with no armature on its basis (I, 2-1-3);3) the mandible, bearing an unusually long and cylindrical process on its first endopodal segment which is tipped with two spines, a peculiar lamina on the second endopodal segment, and an oligomerous exopod (I, 2-1-4); 4) the labrum being elongate and pointed apically $(I, 2-1-5) ; 5)$ the first maxilla unilobate (I, $2-1-7-1)$; and 6) the cuticular sacs of the first and second legs with unique contour (I, 2-1-7-4). It is unlikely that all of these features have derived from the plesiomorphic features of the cyclopoids by simple reduction or degeneration; rather, I deem them to be features intrinsic with the ergasilid lineage. I believe that the ergasilids constitute a distinct phylogenetic group, probably at the level of order, though related to the Gyclopoida.

\section{3-4. Phylogeny of the poecilostome Cyclopoida.}

Those poecilostome cyclopoids, such as the taeniacanthiforms, Hemicyclops and probably Oncaea that share some characteristic naupliar features, are distinguishable from the other poecilostome cyclopoids. Their shared features are: 1) the second antenna bearing a significantly long spine on the basis (see I, 2-1-3), 2) the labrum ornamentation of the taeniacanthiform ( $I, 2-1-5)$, and 3 ) the mandibular endopod with developed spine(s) on the second segment (I, 2-1-4). Additionally, both the taeniacanthiforms and Hemicyclops have the first pair of the remarkable stout spines as a furcal armature appeared after the third naupliar stage (I, 2-1-1). On the other hand, the nauplii of the other poecilostome cyclopoids, such as the Lichomolgidae, Sabelliphilidae, Philoblennidae, Myicolidae, Anthessiidae, Philichthyidae, Sarcotacidae, and Chondracanthidae, exhibit the following features in common (whenever their nauplii are not reduced): 1) the longest spine on the basis of the second antenna is moderate developed (I, 2-1-3), 2) the ornamentation of the labrum is lichomolgiform (I, 2-1-5), 3) the mandibular endopod has no spine (I, 2-1-4), and 4) the first pair of short spines in the furcal armature are not stout (I, 2-1-1). 
Thus, exclusive of the ergasilids, two major groups are discernible in the poecilostome Cyclopoida : the taeniacanthiforms, Hemicyclops and Oncae constitute one group, and the Lichomolgidae, Sabelliphilidae, Philoblennidae, Myicolidae, Anthessiidae, Philichthyidae, Sarcotacidae, and Chondracanthidae constitute the other group. I consider these two groups represent two phylogenetic "stems". For the sake of convenience, I would like to call the former the antehemicyclops stem and the latter the antelichomolgus stem. The members of taeniacanthiform group, which includes the families Taeniacanthidae, Bomolochidae, Tegobomolochidae, Tuccidae, and Telsidae as mentioned in previous chapter $(I, 2-1-1)$, are united by a characteristic feature that is their nauplii carry a distinct caudal process $(I, 2-1-1)$, though it is still unknown in the Tuccidae and Telsidae.

Although I have tried to clarify the phylogenetic meanings of these "stems" to consider the phylogeny within the poecilostome Gyclopoida, some existing problems prevent further work. In fact, within the poecilostome Cyclopoida, there are many families which yield much reduced nauplii or whose nauplii are unknown at all. For example, Gooding (1963) proposes nereicoliform group which includes the families Clausidiidae, Glausiidae, Nereicolidae, Eunicicolidae, Synaptiphilidae, Catiniidae, Anomopsyllidae, and Echiurophilidae. In these families, the nauplii are known only from Hemicyclops of the Clausidiidae and Serioides of the Nereicolidae, and furthermore, the nauplii of Serioides are very reduced (II, 1-1). Thus, further phylogenetic discussion on this group can not be made on the basis of these known nauplii. For further phylogenetic studies of the poecilostome Gyclopoida information on the nauplii of other families are indispensable and the features on the copepodid stages must also be taken into consideration. It is difficult to ascertain phylogenetic relationships from the comparison of extremely reduced nauplii. In this case, copepodid stages, especially the first stage may offer significant information for phylogenetic consideration. I am now engaged in a similar comparative study on the copepodids of the poecilostome Cyclopoida, hoping to clarify the phylogeny of the poecilostome Cyclopoida on the basis of all available ontogenetic information, nauplii as well as copepodids.

\section{Summary}

1. The present paper consists of two parts. In Chapter I, features of phylogenetic implications found in the egg and naupliar stages of the poecilostome Cyclopoida were assessed based on my own observations and descriptions so far published by other researchers.

Morphological features of the nauplii of the poecilostome Cyclopoida were generalized and then compared with those of other copepods, as well as other maxillopodan groups and Cephalocarida.

In Chapter II, a possible scenario of the abbreviation of the naupliar stage was proposed on the basis of the characteristic features of each respective stages and the significance of such abbreviation was also examined. 
Some features of maxillopodan nauplii were compared with the fossil arthropod larvae of the Upper Cambrian.

Characteristic naupliar features of major copepod groups were ascertained. With this respect, systematic position of some cyclopoids, which were unclear due to their profound deformation and degeneration, were proposed. Finally, the constituents of poecilostome Cyclopoida were discussed from a phylogenetic view point and problems are identified for further consideration of their phylogeny.

2. In poecilostome Cyclopoida eggs are usually laid in a pair of egg sacs carried by the female, though there are some other types of spawning. Unlike those of the Caligoida and Lernaeopodoida the egg sacs in Cyclopoida are very weak and easily detached. The eggs are multiseriate, though single row as in Caligoida is also known. However, the uniseriate eggs of the poecilostome Cyclopoida are clearly different from the caligoid eggs, they are never flattened. The feature of egg sac and the arrangement of eggs in a sac seem to be characteristic to taxa.

Although the Myicolidae and Gastrodelphyidae yield eggs larger than $200 \mu \mathrm{m}$ in diameter, the egg size of other poecilostome Cyclopoida falls in a range from 40 to $150 \mu \mathrm{m}$ in diameter. This means that the eggs of poecilostome cyclopoids are clearly smaller than those of the Caligoida and Lernaeopodoida; furthermore, the range of the former is much wider than the latter, reflecting their various mode of life from free-living to parasitic.

Accumulation of yolk in the egg and the increase of egg size in the parasitic or semi-parasitic forms are considered independent events in evolution. The feeding behavior of the hatched nauplius is determined by the egg size. The minimal egg size which yields lecithotrophic nauplius is estimated at about $120 \mu \mathrm{m}$ in diameter.

3. Two kinds of morphological changes are discernible during the naupliar development. First is the minor changes involving completion of second antennae and mandibles as feeding apparatus. This process is usually performed in the nonabbreviated second and third stages. The second is a serial changes directed toward the formation of the first copepodid, it is achieved chiefly through the last three naupliar stages.

4. Accumulation of yolk in the egg causes, in addition to the production of lecithotrophic nauplii, morphological simplification and abbreviation of naupliar stage in unrelated lineages. Morphological simplification proceed first in the feeding parts of the second antennae and mandibles and then in other structures including cuticular outgrowths for the formation of the first copepodid.

5. Abbreviation of the naupliar stage starts by omission of the original second stage and then proceeds by eliminating the new second stage. The first stage nauplius is of particular significance in the naupliar abbreviation, because body form of the later stages to be omitted is developing within it.

6. The degree of naupliar stage reduction reflects the history of the respective group or lineage, and so it is an indicator of the relative time lapse since their ancestor began parasitic mode of life.

7. Copepod nauplii are distinctly different from those of the other Maxillopoda 
and Cephalocarida. However, they bear certain features in common especially the essential structures in the three pairs of appendages; viz. ornamentation of the first antenna regardless of segmentation, and structures and ornamentation in the second antenna and mandible. Some copepod nauplii possess a caudal process, which is considered homologous to the one found in the nauplii of the Cirripedia, Ascothoracida, Facetotecta and Mystacocarida.

Some recently discovered fossil arthropod larvae from the Upper Cambrian are recognized to exhibit a great affinity with the maxillopodan nauplii.

8. The nauplii of the three major copepod groups are distinctly different from each other in characteristic features or combination of features in the later stages.

In general, the nauplii of the Cyclopoida bear resemblances to those of the Harpacticoida. The nauplii of Canuella and Longipedia of the Harpacticoids bear many features in common with the generalized nauplii of the poecilostome Cyclopoida. However, the nauplii of the Calanoida exhibit many distinguishable characteristics.

9. Two types of apical setation in the mandibular exopod are recognized in the nauplii of copepods as well as of other maxillopodans. By using this feature, systematic positions of some problematic cyclopoids are resolved. The families Antheacheridae, Mesoglicolidae and Herpyllobiidae, and Gonophysema incertae sedis are proposed to be placed in the poecilostome Cyclopoida, while the Spondinticolidae and Xenocoelomidae, in the siphonostome Cyclopoida.

10. The Phyllodicolidae, which is currently placed in the poecilostome Cyclopoida, is suggested to be removed from Cyclopoida.

11. The Ergasilidae clearly differs from the other poecilostome copepods in certain naupliar structures. It is related to the Gyclopoida but qualified to be in a separate group.

12. Based on naupliar structures, two major groups are distinguished within the poecilostome cyclopoida, exclusive of the ergasilids: antehemicyclops group, including Hemicyclops, the taeniacanthiforms and oncaeids, and antelichomolgus group, including the Lichomolgidae, Sabelliphilidae, Philoblennidae, Myicolidae, Anthessiidae, Philichthyidae, Sarcotacidae and Chondracanthidae.

\section{Acknowledgments}

I am most grateful to the late Professor S.M. Shiino, Prefectural University of Mie, who led me to the fascinating field of study of parasitic Copepoda. I am grateful to the late Professor H. Utinomi, Seto Marine Biological Laboratory of Kyoto University, for his acceptance of me as a long-term visiting scientist, and to the staff of the same Laboratory for their courtesy extended to me during my stay in 1971-1972. I am greatly indebted to the former Professor T. Tokioka, Seto Marine Biological Laboratory of Kyoto University, for his guidance and advice on my work. I would like to express my sincere gratitudes to Professor E. Harada and Dr. T. Itô, Seto Marine Biological Laboratory, and to Professor J.-S. Ho, Galifornia State University, for their reading and comments on the manuscript. I am also grateful to Professor T. Kajihara, the Ocean Research Institute of Tokyo University, Dr. Z. Kabata, the Pacific Biological Station of Canada, and Professor S. Nishimura, Kyoto Univresity, for their advice and encouragement, and to Dr. S.-I. Uéno, the National Science Museum 
(Nat. Hist.), and Professor S. Ooishi and Dr. H. Sekiguchi, Mie University, for their kindness in help with literatures. I wish also to express my cordial thanks to the former Professor K. Suzuki, Professor T. Nonoda, Dr. M. Nagoshi, Professor I. Hidaka, and Professor H. Noda, Mie University, for their encouragement.

\section{References}

Achituv, Y. 1986. The larval development of Chthamalus dentatus Krauss (Cirripedia) from South Africa. Crustaceana, 51: 259-269.

Amelina, L. 1927. Die süsswasser Cyclopoidenlarven. Arb. Biol. Stat. Kossino, 6: 37-39.

Anderson, D.T. \& G.T. Rossiter. 1969. Hatching and larval development of Haplostomella australiensis Gotto (Copepoda, Fam. Ascidicolidae), a parasite of the ascidian Styela etheridgii Herdman. Proc. Linn. Soc. N.S. Wales, 93: 464-475.

Avdeev. G.V. 1978. Systematic position of the genus, Tegobomolochus Izawa, 1976 (Copepoda, Cyclopoida). Izv. TINRO, 102: 119-122. (In Russian)

Barker, M.F. 1976. Culture and morphology of some New Zealand barnacles (Crustacea: Girripedia). N. Z. J. Mar. Freshw. Res., 10(1): 139-158.

Barnes, H., \& M. Barnes. 1959a. The naupliar stages of Balanus nubilis Darwin. Can. J. Zool., 37 : $15-23$.

, \& - 1959b. The naupliar stages of Balanus hesperius Pilsbry. Ibid., 37: 237-244.

Bassindale, R. 1936. The developmental stages of three English barnacles, Balanus balanoides (Linn.), Chthamalus stellatus (Poli), and Verruca stroemia (O.F. Müller). Proc. Zool. Soc. London, 106: $57-64$.

Ben Hassine, O.K. 1983. Les copépodes parasites de poissons Mugilidae en Méditerranée occidentale (côtes Françaises et Tunisiennes). Morphologie, Bioecologie, Gycles évolutifs. Pp. i-vi, 1-471. Thèse, Univ. Sci. et Techniq., Langedoc.

Bernard, M. 1963. Le cycle vital en laboratoire d'un copépode pélagique de Méditerranée Euterpina acutifrons Claus. Pelagos, $1: 35-48$.

-1964. Le développement nauplien de deux copépodes carnivores: Euchaeta marina (Prestandr.) et Candacia armata (Boeck). Ibid., 2: 51-71.

Björnberg, T.K.S. 1966. The developmental stages of Undinula vulgaris (Dana) (Copepoda). Crustaccana, 11: 65-76.

- 1972. Developmental stages of some tropical and subtropical planktonic marine copepods. Stud. Fau. Gur. Carib. Isls., 40: 1-185.

Bocquet, C., J.H. Stok \& G. Kleeton. 1963. Copépodes parasites d'invertébrés des côtes de la Manche. XI. Sur le développment de Trochicola entericus Dollfus, 1914, copépode cyclopoïde parasite de Trochidae. Arch. Zool. Exp. Gén., 102: 49-68.

Bouligand, Y. 1966. Récherches recentes sur les copépodes associés aux anthozoaires. In: The Cnidaria and their Evolution. W.J. Rees, ed. 449 pp. Academic Press, New York, etc.

Bourguet, J.-P. 1986. Contribution á l'étude de Cletocamptus retrogressus Schmankevitch, 1975 (Copepoda, Harpacticoida) II. developpment larvairestages naupliens. Grustaceana, 51: 113-122.

Bowman, T.E., \& L.G. Abele. 1982. Classification of the recent Crustacea. In: The Biology of Grustacea. L.G. Abele, ed. 319 pp. Academic Press, New York, etc.

Boxshall, G.A. 1974. The developmental stages of Lepeophtheirus pectoralis (Müller, 1776) (Copepoda: Caligidae). J. Nat. Hist., 8: 681-700.

Bresciani, J. 1960. Some features of the larval development of Stenhelia (Delavalia) palustris Brady, 1868 (Copepoda Harpacticoida). Vidensk. Medd. Fra Dansk Naturh. Foren. 123: 237-247.

-. 1965. Nauplius "Y" Hansen. Its distribution and relationship with a new cypris larva. Ibid., 128: 245-258.

—, \& J. Lützen. 1960. Gonophysema gullmarensis (Copepoda parasitica), an anatomical and biological study of an endoparasite living in the ascidian Ascidiella aspersa. I. Anatomie. Cah. Biol. Mar., 1: 157-184, pls 1-7.

, \& 1961. Ditto. II. Biology and development. Ibid., 2: 347-371, pls 1, 2. 
- 1962 . Parasitic copepods from the west ocast of Sweden includgin some new or little known species. Vidensk. Medd. Fra Dansk. Naturh. Foren., 124: 367-408.

- 1974 . On the biology and development of Aphanodomus Wilson (Xenocoelomidae), a parasitic copepod of polychaete Thelepus cincinnatus. Ibid., 137: 25-63.

—_ \& $\&$. 1975. Melinnacheres ergasiloides M. Sars, a parasitic copepod of the polychacte Melinna cristata, with notes on multiple infections caused by annelidicolous copepods. Ophelia, 13: $31-41$.

Briggs, R.P. 1977. Larval stages of Paranthessius anemoniar Claus (Copepoda, Cyclopoida), an associate of the snakelocks anemone Anemonia sulcata (Pennant). Crustaceana, 33: 249-258.

Cabbal, P., F. Coste \& A. Raibaut. 1984. Gycle évolutif de Lernanthropus kroyeri van Beneden, 1851, copépode branchial hématophage du loup Dicentrarchus labrax (Linné, 1758) dans des populations naturelles et en elevage. Ann. Parasitol. Hum. Comp., 59: 189-207.

Campbell, M.H. 1934. The life history and post embryonic development of the copepods, Calanus tonsus Brady and Euchaeta japonica Marukawa. J. Biol. Bd. Can., 1: 1-65.

Canu, E. 1892. Les copépodes du Boulonnais: Morphologie, embryologie, taxonomie. Trav. Lab. Zool. Marit. Wime.-Ambl., 6: 1-354, pls 1-30.

Carter, M.E., \& J.M. Bradford. 1972. Postembryonic development of three species of freshwater harpacticoid Copepoda. Smiths. Contr. Zool., 119: 1-26.

Carton, Y. 1964. Description de Selioides bocqueti n. sp., copépode cyclopoide parasite de Scalisetosus assimilis MacIntosh, Aphroditidae commensal d'Echinus esculentus L. Arch. Zool. Exp. Gén., 102: 83-103.

1968. Development de Cancerilla tubulata Dalyell parasite de l'ophiure Amphipholis squamata Della Chiaje. Crustaceana, Suppl. 1: 11-28.

Caspers, H. 1939. Uber Vorkommen und. Metamorphose von Mytilicola inleslinalis Steuer (Copepoda. paras.) in der südlichen Nordsee. Zool. Anz., 126: 161-171.

Caullery, M., \& F. Mensil. 1919. Xenocoetoma brumpti C. et M. Copépode parasite de Polycirrus arenivorus C. Bull. biol. Fr. Belg. 53: 161-233, pls 1-4.

Changeux, J.-P. 1957. Description du deux stades larvaires d'un copépode Cancerillidac, parasite sur Ophiopsila aranea Forbes. Vie Milieu, 8: 297-311.

- 1961. Contribution a l'etude des animaux associes aux holothurides. Ibid., Suppl. (10): $1-124$.

Chatton, E. 1909. Sur un nauplius double anadydyne d'Ophioseides joubini Chatton. Compt. Rend. Soc. Biol., 2: 482-484.

Chiba, T. 1956. Studies on the development and the systematics of Copepoda. J. Shimonoseki Coll. Fish., 6: 1-90. (In Japanese)

Claus, G. 1887. Ueber Lernaeascus nematoxys Cls. und die Familie der Philichthyden. Arb. Zool. Inst. Wien, $7(2): 1-35$, pls $1-4$.

Comita, G.W., \& D.M. Tommerdahl. 1960. The postembryonic developmental instars of Diaptomus siciloides Lilljeborg. J. Morph. 107: 297-356, Pls. 1-18.

Connolly, C.J. 1929. A new copepod parasite Choniosphaera cancrorum, gen. et sp. n., representing a new genus, and its larval development. Proc. Zool. Soc. London, part 3, 1929: 415-427.

Conover, R.J. 1956. Biology of Acartia clausi and A. tonsa. Bull. Bing. Oceanogr. Goll., 15: 156233.

Costanzo, G. 1959. Sullo sviluppo di Mytilicola inlestinalis Steuer (Crost. Cop.). Arch. Zool. Ital., 44: 151-163.

- 1969. Stadi naupliari e primo copepodite di Lichomolgus canui G.O. Sars (Copepoda, Cyclopoida) del lago di Faro (Messina), allevata sperimentalmente. Boll. Zool., 36: 143-153.

Costlow, J.D., Jr. \& C.G. Bookhout. 1958. Larval development of Balanus amphitrite var denticulata Broch reared in the laboratory. Biol. Bull., 114: 284-295.

Dalley, R. 1984. The larval stages of the oceanic, pedunculate barnacle Conchoderma auritum (L.) (Cirripedia, Thoracica). Crustaceana, 46: 39-54.

Delamare-Deboutteville, C. 1954. Le développement postembryonnaire des Mystacocarides. Arch. Zool. Exp. Gén., 91 : 25-34. 
, \& L. Laubier. 1960. Les Phyllocolidae, une famille nouvelle d coppodes parasites d'annélides polychétes. C.R. Acad. Sc. Paris, 251: 2083-2085.

Diaz, W., \& F. Evans. 1983. The reproduction and development of Microsetella norvegica (Boeck) (Copepoda, Harpacticoida) in Northumberland coastal waters. Crustaceana 45: 113-130.

Dietrich, W. 1915. Die Metamorphose der freilebenden Süsswasser-Copepoden. 1. Die Nauplien und das erste Copepodidstadium. Zeit. Wiss. Zool., 113: 252-323.

Do, T.T., T. Kajihara \& J.-S. Ho. 1984. The life history of Pseudomyicola spinosus (Raffaele \& Monicelli, 1885) from the blue mussel, Mitilus edulis galloprovincialis in Tokyo Bay, Japan, with notes on production of atypical male. Bull. Ocean Res. Inst. Univ. Tokyo, (17): 1-65.

Dojiri, M. \& R.F. Cressey. 1987. Revision of the Taeniacanthidae (Copepoda: Poecilostomatoida) parasitic on fishes and sea urchins. Smiths. Cont. Zool., 447: 1-250.

Dudley, P.L. 1964. Some gastrodelphyid copepods from the Pacific coast of North America. Amer. Mus. Novit. 2194: 1-51.

- 1966. Development and systematics of some Pacific marine symbiotic copepods. Pp. 1-282. Univ. Washington Press, Seattle and London.

Egan, E.A. \& D.T. Anderson. 1986. Larval development of Balanus amphitrite Darwin and Balanus variegatus Darwin (Girripedia, Balanidae) from New South Wales, Australia. Crustaceana, 51: 188-207.

Elgmork, E., \& A.L. Langeland. 1970. The number of naupliar instars in Gyclopoida (Copepoda). Crustaceana, 18: 277-282.

El-Maghraby, A.M. 1964. The developmental stages and occurrence of the copepod Euterpina acutifrons Dana in the marine environment of Alexandria, U. A. R. Ann. Mag. Nat. Hist., Ser. 13, 7: 223-233.

Faber, D.J. 1966. Free-swimming copepod nauplii of Narragansett Bay with a key to their identification. J. Fish. Res. Bd. Canada, 23: 189-205.

Fischer, W. 1956. Untersuchungen über einen für die deutsche Bucht neuen parasitären Copepoden: Lecithomyzon maenadis Block \& Gallien (Familie Choniostomatidae) au Carcinus maenas Pennant (Crustacea Decapoda). Helgol. Wiss. Meer., 5: 326-352.

Fraser, C.M. 1936. The occurrence, ecology and ilfe history of Tigriopus fuluus (Fischer). J. Mar. Biol. Ass. U.K., 20: 523-536.

Fryer, G. 1956. A report on the parasitic Copepoda and Branchiura of the fishes of Lake Nyasa. Proc. Zool. Soc. London, 127: 293-344.

Gaudy, R. 1961. Note sur les stades larvaires de Temora stylifera Dana. Rec. Trav. St. Mar. End., $22(36): 115-122$.

Gibbons, S.G., \& H.S. Ogilvie. 1933. The developmental stages of Oithona helgolandica and Oithona spinirostris, with a note on the occurrence of body spines in cyclopoid nauplii. J. Mar. Biol. Ass. U.K. (NS), 18: 529-550.

Gnanamuthu, G.P. 1951. Notes on the life history of a parasitic copepod, Lernaea chackoensis. Parasitology, 41(3-4): 148-155.

Gooding, R.U. 1963. External morphology and classification of marine poecilostome copepods belonging to the families Clausidiidae, Clausiidae, Nereicolidae, Eunicicolidae, Synaptiphilidae, Catiniidae, Anomopsyllidae, and Echiurophilidae. 275 pp. Thesis of Ph. D. Univ. Washington, 1963, Univ. Microfilms, Michigan.

Goswami, S.C. 1975. Metamorphosis of two species of genus Oithona Baird (Copepoda). Indian J. Mar. Sci., 4: 60-67.

Gotto, R.V. 1957. The biology of a commensal copepod, Ascidicola rosea Thorell, in the ascidian Corella parallelogramma (Müller). J. Mar. Biol. Ass. U.K., 36: 281-290.

-1961. A possible phylogenetic inetrpretation of the annelidicolous copepod Phyllocola petiti Delamare \& Laubier. Evolution, 15: 564-565.

-1963. Observations on the structure, affinities and biology of a rare copepod, Eunicicola (formerly Eurynotus) insolens (T. \& A. Scott). Proc. Zool. Soc. London, 140: 47-56. 109. 
Grabda, J. 1963. Life cycle and morphogenesis of Lernaea cyprinacea L. Acta Parasitol. Polonica, 11: 169-918, pl. 1 .

Gravier, C. 1913. Crustaces parasites. 2e Expéd. Antarct. Française (1908-1910): 27-78.

Gray, P. 1933. Mycophilus rosovula n. sp., a notodelphoid copepod parasitic within B. (Botrylloides) leachii Sav., with a description of the nauplius and notes on the habits. J. Mar. Biol. Ass. U.K., 18: $523-528$.

Grice, G. 1969. The developmental stages of Pseudodiaptomus coronatus Williams (Copepoda, Calanoida). Crustaceana, 16:291-301.

Groom, T.T. 1894. On the early development of Cirripedia. Phil. Trans. Roy. Soc., B, 185: 119232, pls $14-28$.

Grygier, M.J. 1985. Comparative morphology and ontogeny of the Ascothoracida, a step toward a phylogeny of the Maxillopoda. Diss. Univ. Calf. Univ. Microf. Inter. Ann Arbor, i-xxi, 1-417.

___ 1987. Nauplii, antennular ontogeny, and the position of the Ascothoracida within the Maxillopoda. J. Crust. Biol., 7: 87-104.

Gurney, R. 1913. Some notes on the parasitic copepod Thersitina gasterostei Pagenstecher. Ann. Mag. Nat. Hist., Ser. 8, 12: 415-424, pls 10-13.

- 1930. The larval stages of the copepod Longipedia. J. Mar. Biol. Ass. U.K., (N.S.), 16: 461-474.

1933. Notes on some Copepoda from Plymouth. Ibid., 19: 299-304.

. 1934a. The development of Rhincalanus. Discover Rep., 9: 207-214.

1934b. The development of certain parasitic Copepoda of the families Caligidae and Clavellidae. Proc. Zool. Soc. London, 1934: 177-217.

Halisch, W. 1940. Anatomie und Biologie von Ergasilus minor Halisch. Zeitschr. Parasitenk., 11: 284-330.

Hanaoka, T. 1944. Nauplius of the fresh-water genus, Cyclops. Suisan Gakkai Ho, 9: 109-137. (In Japanese)

- 1952a. Study on free-living Copepoda-nauplius. Bull. Naikai Reg. Fish. Res. Lab., Japan, (1): 1-36. (In Japanese with English summary)

-1952b. On nauplius of Oncaea mediterranea and Corycaeus sp. Ibid., (2): 37-41. (In Japanese with English summary)

Haq, S.M. 1965a. The larval development of Oithonina nana. J. Zool., 146: 555-566.

- 1965b. Development of the copepod Euterpina acutifrons with special reference to dimorphism in the male. Proc. Zool. Soc. London, 144: 175-201.

Heegaard, P. 1947. Contribution to the phylogeny of the arthropods Copepoda. Spolia Zool. Mus. Hauniensis, 8: 1-236, pls 1-27.

Hessler, R.R. \& H.L. Sanders. 1966. Derocheilocaris typicus Pennak \& Zinn (Mystacocarida) revisited. Crustaceana, 11: 141-155.

Hirakawa, K. 1974. Biology of a pelagic harpacticoid copepod, Microsetella norvegica Boeck in Oshoro Bay, Hokkaido. Bull. Plankt. Soc. Japan, 21: 41-54.

Hjort, J. 1895. Zur Anatomie und Entwicklungsgeschichte einer im Fleisch von Fischen schmarotzenden Crustacée (Sarcotaces arcticus Collett). Vid.-Selsk. Skrifter. M.-N. Kl. 1895, 2: 3-14, figs $1-10$.

Ho, J.-S. 1980. Anchicaligus nautili (Willey), a caligid copepod parasitic on Nautilus in Palau, with discussion of Caligulina Heegaard, 1972. Publ. Seto Mar. Biol. Lab., 25: 157-165.

- 1984. New family of poecilostomatoid copepods (Spiophanicolidae) parasitic on polychaetes from Southern California, with a phylogenetic analysis of nereicoliform families. J. Crust. Biol., 4: 134-146.

Hoshina, T. \& R. Kuwabara. 1959. On a new commensal copepod, Mytilicola mactrae n. sp. observed from the intestine of Mactra veneriformis Reeve. J. Tokyo Univ. Fish., 45: 33-35, pls 1, 2.

Humes, A.G. 1955. The postembryonic developmental stages of a fresh-water calanoid copepod, Epischura massachusettsensis Pearse. J. Morph., 96: 441-471, pls 1-6.

- 1986. Myicola metisiensis (Copepoda: Poecilostomatoida), a parasite of the bivalve Mya 
arenaria in eastern Canada, redefinition of the Myicolidae, and diagnosis of the Anthessiidae n. fam. Can. J. Zool., 64: 1021-1033.

— \& J.H. Stock. 1973. A revision of the family Lichomolgidae Kossmann, 1877, cyclopoid copepods mainly associated with marine invertebrates. Smiths. Cont. Zool., 127: i-v, 1-368.

Hwa, T.-K. 1965. Studies on the life history of a fishlouse (Caligus orientalis Gussev). Acta Zool. Sinica, 17: 48-58, pls 1-4.

Itô, T. 1970. The biology of a harpacticoid copepod, Tigriopus japonicus Mori. J. Fac. Sci. Hokkaido Univ., Ser. VI, Zool., 17: 474-500.

- 1975. Biological studies on the family Harpacticidae Sars from Japan, with reference to the phylogeny within the subfamily Harpacticellinae Lang (Copepoda: Harpacticoida). 330pp. Thesis Hokkaido Univ.,

- 1985. Contributions to the knowledge of cypris y (Crustacea: Maxillopoda) with reference to a new genus and three new species from Japan. Spec. Publ. Mukaishima Mar. Biol. Stat., 1985: 113-122.

—_. 1986. Three types of "nauplius y" (Maxillopoda: Facetotecta) from the North Pacific. Publ. Seto Mar. Biol. Lab., 31: 63-73.

- - \& T. Takashio. 1981. The larval development of Canthocamptus mirabilis Sterba (Copepoda, Harpacticoida), with reference to the bionomics. J. Fac. Sci. Hokkaido Univ., Ser. VI, Zool., 22: 279-300.

Izawa, K. 1967. On a new parasitic copepod, Taeniacanthus canthigasteri n. sp., found on Ganthigaster rivulata (Crustcea, Gyclopoida, Bomolochidae). Rep. Fac. Fish. Pref. Univ. Mie, 6: 29-40.

- 1969. Life history of Caligus spinosus Yamaguti, 1939 obtained from cultured yellow tail, Seriola quinqueradiata T. \& S. (Crustacea: Caligoida). Ibid., 6: 127-157.

- 1973. On the development of parasitic Copepoda I. Sarcotaces pacificus Komai (Gyclopoida: Philichthyidae). Publ. Seto Mar. Biol. Lab., 21: 77-86.

- 1974. Sarcotaces, a genus of parasitic copepods (Cyclopoida: Philichthyidae), found on Japanese fishes. Ibid., 21: 179-194.

- 1975. On the development of parasitic Copepoda II. Colobomatus pupa Izawa (Cyclopoida: Philichthyidae). Ibid., 22: 147-155.

1976. Two new parasitic copepods (Cyclopoida: Myicolidae) from Japanese gastropod molluscs. Ibid., 23: 213-227.

- 1986a. On the development of parasitic Copepoda III. Taeniacanthus lagocephali Pearse (Cyclopoida: Taeniacanthidae), Ibid., 31:37-54.

- 1986b. On the development of parasitic Copepoda. IV. Ten species of poecilostome cyclopoids, belonging to Taeniacanthidae, Tegobomolochidae, Lichomolgidae, Philoblennidae, Myicolidae, and Chondracanthidae. Ibid., 31: 81-162.

Johnson, G. 1969. A contribution to the biology of Corycaeus anglicus, a marine cyclopoid copepod. MS Dissertation, Scripps Inst. Oceanogr.

Johnson, M.W. 1934a. The life history of the copepod Tortanus discaudatus (Thompson and Scott). Biol. Bull., 67: 182-200.

- 1934b. The developmental stages of the copepod Epilabidocera amphitrites McMurrich. Ibid., 67: 466-483.

- 1935. The developmental stages of Labidocera. Ibid., 68: 397-421.

- 1937. The developmental stages of the copepod Eucalanus elongatus Dana var. bungii Giesbrecht. Trans. Amer. Micro. Soc., 56: 79-98.

- 1948. The postembryonic development of the copepod Pseudodiaptomus euryhalinus Johnson, and its phylogenetic significance. Ibid., 68:319-330.

- 1953. The copepod Cyclops dimorphus Kiefer from the Salton Sea. Amer. Midland. Naturalist, $49: 180-192$.

- 1957. The copepod Choniosphaera cancrortm parasitizing a new host, the green crab Carcinides maenas. J. Parasit., 43: 470-473.

1965. The nauplius larvae of Pontellopsis occidentalis Esterly (Copepoda, Calanoida). Trans. Amer. Micro. Soc., 84: 43-48. 
1966. The nauplius larvae of Eurytemora herdmani Thompson \& Scott, 1897 (Copepoda, Calanoida). Crustaceana, 11: 307-313.

—, \& J.B. Olson. 1948. The life history and biology of a marine harpacticoid copepod, Tisbe furcata (Baird). Biol. Bull., 95: 320-332.

Jones, L.W. \& D.J. Crisp. 1954. The larval stages of the barnacle Balanus improvisus Darwin. Proc. Zool. Soc. London, 123: 765-780.

Kabata, Z. 1972. Developmental stages of Caligus clemensi (Copepoda: Caligidae). J. Fish. Res. Bd. Canada, 29: 1571-1593.

1976. Early stages of some copepods (Crustacea) parasitic on marine fishes of British Columbia. Ibid., 33: 2507-2525.

-... 1979. Parasitic Copepoda of British Fishes. Pp. i-xii, 1-468, figs 1-2031. Ray Soc., London.

Kasahara, S. 1962. Studies on the biology of the parasitic copepod Lernaea cyprinacea Linnacus and the methods for controlling this parasite in fishculture ponds. Contrib. Fish. Lab. Fac. Agr. Univ. Tokyo, (3): 103-196, pls 1, 2. (In Japanese, with English synopsis)

Kawatow, K., K. Muroga, K. Izawa \& S. Kasahara. 1980. Life cycle of Alella macrotrachelus (Copepoda) parasitic on cultured black sea-bream. J. Fac. Appl. Biol. Sci., Hiroshima Univ., 19: $199-214$.

Knight-Jones, E.W. \& G.D. Waugh. 1949. On the larval development of Elminius modestus Darwin. J. Mar. Biol. Ass. U.K., 28: 413-428.

Kô, Y. 1969. External anatomy of a commensal copepods, Ostrincola koe-I. Copepodid stage. Bull. Fac. Fish. Nagasaki Univ., 28: 93-109. (In Japanese with English summary)

$\longrightarrow$ K. Yoshikoshi \& N. Ito. 1974. External anatomy of a commensal copepod, Ostrincola koeII. Nauplius stage. Ibid., (38): 87-93. (In Japanese with English summary)

Koga, F. 1960a. The developmental stages of nauplius larvae of Pareuchaeta russelli (Farran). Bull. Jap. Soc. Sci. Fish., 26: 792-796.

1960b. The nauplius larvae of Centropages abdominalis Sato. Ibid., 26: 877-881.

. 1968. On the nauplius of Undinula vulgaris (Dana) (Gopepoda, Calanoida). J. Oceanogr. Soc. Japan, 24: 173-177.

--. 1973. Life history of copepods especially of nauplius larvae ascertained mainly with cultivation of animals. Bull. Plankt. Soc. Japan, 20: 30-40.

- 1984. Morphology, ecology, classification and specialization of copepods nauplius. Bull. Nansei Reg. Fish. Res. Lab., 16: 95-229. (In Japanese)

Komai, T. 1924. Notes on Sarcotaces pacificus, n. sp., with remarks on its systematic position. Mem. Coll. Sc. Kyoto Imp. Univ., Ser. B, 1: 265-271, Pl. 17.

Krishnaswamy, S. 1950. Development of a harpacticoid copepod, Macrosetella gracilis (Dana). J. Madras Univ., 21 : 256-271.

- 1955. Life history of the psammophilous copepod Leptastacus euryhalinus. Ibid., 25: 353359.

Kuitunen-Ekbaum, E. 1949. The occurrence of Sarcotaces in Canada. J. Fish. Res. Bd. Canada, 7 : $505-512$.

Kurz, W. 1877. Eunicicola clausii, ein neuer Annelidenparasit. Sitzb. Wiener Akad. Wissens., 75: 21-28, Pls. 1, 2.

Lacaze-Duthiers, H. 1883. Histoire de Ia Laura gerardiae: type nouveau de crustacé parasite. Mem. Acad. Sci. Inst. Fr., 42(2): 1-160.

Lang, K. 1948a. Copepoda (Notodelphyoida) from the Swedish west-coast with an outline on the systematics of the copepods. Ark. Zool., 40A (14) : 1-36, Pl. I.

1948b. Monographie der Harpacticiden. Pp. 1682. Hakan Ohlssons Boktryckeri, Lund.

1949. On some Swedish marine semi-parasitic and parasitic copepods. Ark. Zool., 42A (22): $1-10$.

Laubier, L. 1961. Phyllodicola petiti (Delamare et Laubier, 1960) et la famille des Phyllodicolidae, copépodes parasites d'annélides polychétes en Méditerranée Occidentale. Crustaceana, 2: 228242.

Lawson, T.J. \& G.D. Grice. 1970. The developmental stages of Centropages typicus Kroyer (Copepoda, 
Calanoida). Crustaceana, 18: 187-208.

Lebour, M.V. 1916. Stages in the life history of Calanus finmarchicus (Gunnerus), experimentally reared by Mr. L.R. Crawshay in the Plymouth laboratory. J. Mar. Biol. Ass. U.K., N. S., 11: 1-17.

Lewis, A.G. \& A. Ramnarine. 1969. Some chemical factors affecting the early developmental stages of Euchaeta japonica (Crustacea: Copepoda: Calanoida) in the alboratory. J. Fish. Res. Bd. Canada, 26: 1347-1362.

Lovegrove, T. 1956. Copepod nauplii (II). Conseil Internat. Explo. Mar, Zooplankton, 63: 1-4. Lützen, J. 1968. On the biology of the family Herpyllobiidae (parasitic copepods). Ophelia, 5: 175187.

Malaquin, A. 1901. Le parasitisme evolutif des Monstrillides (Crustacés Copépodes). Arch. Zool. Exp. Gén. (3) 9: 81-232.

Malt, S.J. 1982. Developmental stages of Oncaea media Giesbrecht, 1891 and Oncaea subtilis Giesbrecht, 1892. Bull. Br. Mus. Nat. His. (Zool.), 43: 129-151.

Matthews, J.B.L. 1964. On the biology of some bottom-living copepods (Aetideidae and Phaennidae) from Western Norway. Sarsia, (16): 1-46.

Mirzoeva, L.M. 1973. Life cycle and morphology of Sinergasilus lieni Yin, 1949 (Copepoda, Parasitica). Trudy Vses. Nauch.-issledo. Inst. Prudo. Ryb. Khoz., 22: 143-158. (In Russian, with English summary)

Müller, K.J. \& D. Walossek. 1986a. Martinssonia elongata eg. et sp. n., a crustacean-like euarthropod from the Upper Cambrian Orsten of Sweden. Zool. Scr., 15: 73 92.

—,$\&$ - 1986b. Arthropod larvae from the Upper Cambrian of Sweden. Trans. Roy. Soc. Edinb. Earth Sci., 77: 157-179.

Murphy, H.E. 1923. The life cycle of Oithona nana, reared experimentally. Publ. Zool. Univ. Calif., $22: 449-454$.

Nakai, N. 1927. On the development of a parasitic copepod, Lernaea elegans Leigh-Sharp, infesting on Cyprinus carpio L. J. Imp. Fish. Inst. Tokyo, 23: 39 86, Pls. 2-4.

Nakamura, K., T. Kajihara \& M. Oka. 1979. Development of a cyclopoid copepod, Pseudomyicola ostreae Yamaguti, associated with a marine mussel, Mytilus edulis galloprovincialis Lamark: external structure of nauplius in six stages. Proc. Jap. Soc. Syst. Zool., (17): 38-44.

Nicholls, A.G. 1934. The developmental stages of Euchaeta norvegica (Boeck). Proc. Roy. Soc. Edinb., 54: 31-51.

- 1935. The larval stages of Longipedia coronata Claus, L. scotti G.O. Sars, and L. minor T. and A. Scott, with a description of the male of $L$. scotti. J. Mar. Biol. Ass. U.K. (N.S.), 20: 2945.

- 1941. The developmental stages of Metis jousseaumei (Richard) (Copepoda, Harpacticoida). Ann. Mag. Nat. His., Ser. 11, 7: 317-328.

Nordmann, A. 1832. Mikrographische Beitrage zur Naturgeschichte der wirbellosen Thiere, Heft 2. Pp. 1-150. G. Reiner, Berlin.

Oberg, M. 1906. Die Metamorphose der Plankton-Copepoden der Kieler Bucht. Wiss. Meeresunters. Abt. Kiel., N.F., 9: 37-103, pls 1-7.

Okada, Y.K. 1938. Les Cirripedes Ascothoraciques. Trav. Stat. Zool. Wimereux, 13: 489-514.

Onbé, T. 1984. The developmental stages of Longipedia americana (Copepoda: Harpacticoida) reared in the laboratory. J. Crust. Biol., 4: 615-631.

Ooishi, S. 1980. The larval development of some copepods of the family Ascidicolidae, subfamily Haplostominae, symbionts of compound ascidians. Publ. Seto Mar. Biol. Lab., 25: 253-292.

Paterson, N.F. 1958. External features and ilfe cycle of Cucumaricola notabilis nov. gen. et sp., a copepod parasitic of holothurian, Cucumaria. J. Parasitol., 48: 269-290.

Pesta, O. 1907. Die Metamorphose von Mytilicola intestinalis Steuer. Zeit. Wiss. Zool., 88: 78-98, pl. 6 .

- 1909. Beitrage zur Kenntnis parasitischer Copepoden. Denskchr. Kais. Ak. Wiss., Math.naturwiss. Kl., Wien., 84: 257-267, pls 1-3.

Pillai, N.K. 1962. Choniomyzon gen. nov. (Copepoda: Choniostomatidae) associated with Panulirus. J. Mar. Biol. Ass. India, 4: 95-99. 
Pyefinch, K.A. 1948. Methods of identification of the larvae of Balanus balanoides (L.), B. crenatus Brug. and Verruca stroemia O.F. Müller. J. Mar. Biol. Ass. U.K., 27: 451-463.

-1949. The larval stages of Balanus crenatus Brugniére. Proc. Zool. Soc. London, 118: $416-923$.

Quidor, A. 1922. Sur "Mesoglicola delagei" Quidor et son hôte. Annls Sci. Nat. Zool., (10) 5: 77-81.

Rao, V.R. 1958. Development of a cyclopoid Copepoda Oithona rigida (Giesbrecht). Andhra Univ. Memo. Oceanogr., Ser. 62, 2: 128-131.

Reddy, Y.R. \& G.R. Devi. 1985. The complete postembryonic development of Megadiaplomus hebes Kiefer, 1936 (Copepoda, Calanoida) reared in the laboratory. Crustaceana, 48: 40-63.

Sanders, H.L. 1963. The Cephalocarida, functional morphology, larval development, comparative external anatomy. Mem. Conn. Acad. Arts \& Sci., 15: 1-80.

-, \& R.R. Hessler. 1963. The larval development of Lightiella incisa Gooding (Cephalocarida). Crustaceana, 7: 81-97.

Sars, G.O. 1918. An account of the Grustacea of Norway. Vol. 6. Copepoda, Cyclopoida. Pp. i-xiii, 1-225, pls 1-118. Bergen Mus., Bergen.

Sars, M. 1870. Bidrag til Kundskab om Christianiafjordens fauna II. Crustacea. Nutt Mag. Naturvid. Kristiania, 113-226, pls 8-13.

Schminke, H.K. 1982. Die Nauplius-stadien von Parastenocaris vicesima Klie, 1935 (Copepoda, Parastenocarididae). Dresera, '82(1): 101-108.

Schram, F.R. 1986. Grustacea. Pp. 1-606. Oxford Univ. Press, New York.

Schram, T.A. 1970. On the enigmatical larva nauplius Y type I. Hansen. Sarsia, 45: 53-68.

1972. Further records of nauplius $\mathrm{Y}$ type IV Hansen from Scandinavian waters. Ibid., $50: 1-24$

- 1979. The life history of the eye-maggot of the sprat, Lernaeenicus spraltae (Sowerby) (Copepoda, Lernaeoceridae). Ibid., 64: 279-316.

Shen, C.-J. \& G.-C. Chang. 1965. Larval development of Metadiaptomus asiaticus Ulganin. Oceanol. Limnol. Sinica, $7:$ 141-150, pls 1-7. (In Chinese with English abstract)

Shiino, S.M. 1932. Ichthyotaces pteroisicola, n. gen. \& n. sp., a copepod parasitic on the fish Plerois lunulata Temm. \& Schl. Ann. Zool. Japon., 13: 417-430, pl. 1.

Shokita, S. 1973. Abbreviated larval development of the fresh-water prawn, Macrobrachium shokitai Fujino et Baba (Decapoda, Palaemonidae) from Iriomote Island of the Ryukyus. Ann. Zol. Japon., 46: 111-126.

Silén, L. 1963. Clinophilus vermicularis n. gen. n. sp., a copepod infecting the burrowing sponge, Cliona. Zool. Bidr. Uppsala, 35: 269-288.

Sollaud, E. 1923. Le développement larvaire des "Palaemoninae". I. Partie descriptive. La condensation progressive de l'ontogénése. Bull. Biol. France. Belg., 57: 509-603.

Sproston, N.G. 1942. The developmental stages of Lernaeocera branchialis (Linn.). J. Mar. Biol. Ass. U.K., 25: 441-466.

- W.Y. Yin \& Y.T. Hu. 1950. The genus Lamproglena (Copepoda parasitica): the discovery of the life-history and males of two Chinese species from food fishes, revealing their relationship with Lernaea, and of both to the Cyclopoidea. Sinensia, N.S., 1: 51-84.

Steuer, A. 1935. Postembryonalentwicklung von Rhincalanus gigas Brady. Sitz. Akad. Wiss. Wien Mathem.-naturw. Klasse, 144: 383-390.

Stock, J.H. 1969. The names of certain cyclopoid copepods associated with invertebrates in the Black Sea. Grustaceana, 17: 220-222.

- - A.G. Humes \& R.U. Gooding. 1963. Copepoda associated with West Indian invertebratesII Cancerillidae, Micropontiidae (Siphonostoma). Stud. Fau. Cur. Car. Isl., 15: 1-23.

Stoliarow, W.P. 1936. Zur Kenntnis des Entwicklungszyklus von Lernaea cyprinacea. Trudy Leningr. Obsc. Estestvoisp., 65: 239-253. (In Russian with German summary)

Tanaka, O. 1961. On copepods associated with marine pelecypods in Kyūshū. J. Fac. Agr. Kyushu Univ., $11: 249-273$, pls 22-37.

Taton, H. 1934. Contribution a l'etude du copépode gallicole Mesoglicola delagei Quidor. Trav. Stat. Biol. Roscoff, 12: 53-68. 
Tesch, J.J. 1915. Quantitative Untersuchungen über das Vorkommen der Copepoden und ihrer Entwicklungsstadien in Plankton bein Haaks-Feuerschiff 1912, mit Einen Anhagen: Die Nauplien und Copepoditen von Euterpina acutifrons (Dana). Rapp. Verh. Rijksinst. Visscher., 1: 269-307.

Thatcher, V.E. \& W.A. Boeger. 1984a. The parasitic crustaceans of fishes from the Brazilian Amazon, 13, Gamidactylus jaraquensis gen. et sp. nov. (Copepoda: Poecilostomatoida: Vaigamidae) from the nasal fossae of Semaprochilodus insignis (Schomburgk). Amazoniana, 8: 421-426.

- $\&$ - 1984b. The parasitic crustaceans of fishes from the Brazilian Amazon, 14, Gamispinus diabolicus gen. et sp. nov. (Copepoda: Poecilostomatoida: Vaigamidae) from the nasal fossae of Ageneiosus breviflis Valenciennes. Ibid., 8: 505-510.

- \& \& - 1984c. The parasitic crustaceans of fishes from the Brazilian Amazon, 15, Gamispatulus schizodontis gen. et sp. nov. (Copepoda: Poecilostomatoida: Vaigmaidae) from the nasal fossae of Schizodon fasciatus Agassiz. Ibid., 9: 119-126.

_ \& B.A. Robertson. 1984. The parasitic crustaceans of fishes from the Brazilian Amazon, 11, Vaigamidae fam. nov. (Copepoda: Poecilostomatoida) with males and females of Vaigamus retrobarbatus gen. et sp. nov, and V. spinicephalus sp. nov. from plankton. Can. J. Zool., 62: 716729 .

Ummerkutty, A.N.P. 1960. Studies on Indian copepods 2. An account of the morphology and life history of a harpacticoid, Tisbintra jonesi, sp. nov. from the Gulf of Mannar. J. Mar. biol. Ass. India, 2: 149-164.

1964. Studies on Indian copepods 6. The postembryonic development of two calanoid copepods, Pseudodiaptomus aurivilli (Cleve) and Labidocera bengalensis (Krishnaswamy). Ibid., 6: $48-60$.

Urawa, S., K. Muroga \& K. Izawa. 1979. Caligus orientalis Gussev (Copepoda) parasitic on Akame (Liza akame). Fish. Pathol., 13: 139-146.

— - \& S. Kasahara. 1980a. Naupliar development of Neoergasilus japonicus (Copepoda: Ergasilidae). Bull. Jap. Soc. Sci. Fish., 46: 941-947.

$\longrightarrow,-1980 \mathrm{~b}$. Studies on Neoergasilus japonicus (Copepoda: Ergasilidae), a parasite of fresh-water fishes-II. Development in copepodid stage. J. Fac. Appl. Biol. Sci. Hiroshima Univ., 19: 21-38.

Uye, S. \& T. Onbé. 1975. The developmental stages of Pseudodiaptomus marinus Sato (Copepoda, Calanoida) reared in the laboratory. Bull. Plankt. Soc. Japan, 21: 65-76.

Vader, W. 1970. Antheacheres duebeni M. Sars, a copepod parasitic in the sea anemone, Bolocera tuediae (Johnston). Sarsia, 43: 99-106.

Valle, A.D. 1880. Sui coriceidi parassiti, e sull'anatomia del gen. Lichomolgus. Mem. Cl. Sc. Fis., Atti Lincei, Ser. 3, 5: 107-124, pls 1, 2.

Vilela, M.H. 1969. The life cycle of Tisbe sp. (Copepoda, Harpacticoida) under Iaboratory conditions. Not. Est. Inst. Biol. Marit., (36): 1-15, pls 1-5.

Vincx, M. \& C. Heip. 1979. Larval development and biology of Canuella perplexa T. and A. Scott, 1893 (Copepoda). Cah. Biol. Mar., 20: 281-299.

Williams, L.W. 1907. A list of the Rhode Island Copepoda, Phyllopoda, and Ostracoda with new species of Copepoda. Rep. Comm. Inland Fish., Rhode Island, 37: 69-79, pls 1-3.

Wilson, G.B. 1905. North American parasitic copepods belonging to the family Caligidae. Proc. U.S. Nat. Mus., 28 (1404): 479-672, pls 5-29.

. 1911. North American parasitic copepods belonging to the family Ergasilidae. Ibid. 39 (1788): 263-400, pls 41-60.

- 1913. Crustacean parasites of West Indian fishes and land crabs with descriptions of new genera and species. Ibid., 44(1950): 189-277, pls 18-53.

1918. The economic relations, anatomy and the life history of the genus Lernaea. Bull. U.S. Bur. Fish., 3(1915-16): 165-198, pls 6-14.

- 1932. The copepods of the Woods Hole region, Massachusetts. Bull. U.S. Nat. Mus., 158: 1-653.

Yin, W.-Y. 1957. Studies on the Ergasilidae (parasitic Copepoda) from the fresh-water fishes of China. Acta Hydrobiol. Sinica, 2: 209-270. 
Yosii, N. 1931a. Note on Myriocladus. J. Fac. Sci. Imp. Univ. Tokyo., Sec. 4, 2: 337-349.

-1931b. Note on the organisation of Baccalaureus japonicus. Ann. Zool. Japon., 13: 169187.

Ziegelmayer, W. 1925. Metamorphose und Wachstum der Cyclopiden. Zeit. Wiss. Zool., 126: $493-470$.

Zmerzlaya, E.1. 1972. Ergasilus sieboldi Nordmann, 1832, its development, biology and epizootic significance. Izv. Gos. Nauchno-Issled. Inst. Ozern. Rechu. Rybn. Khoz., 80: 132-177. (In Russian with English summary) 